\title{
Fúpiris
}

THE

SEA OTtER.

\author{
BY \\ ALEXANDER ALLAN.
}

$7 / 6$ NET. 


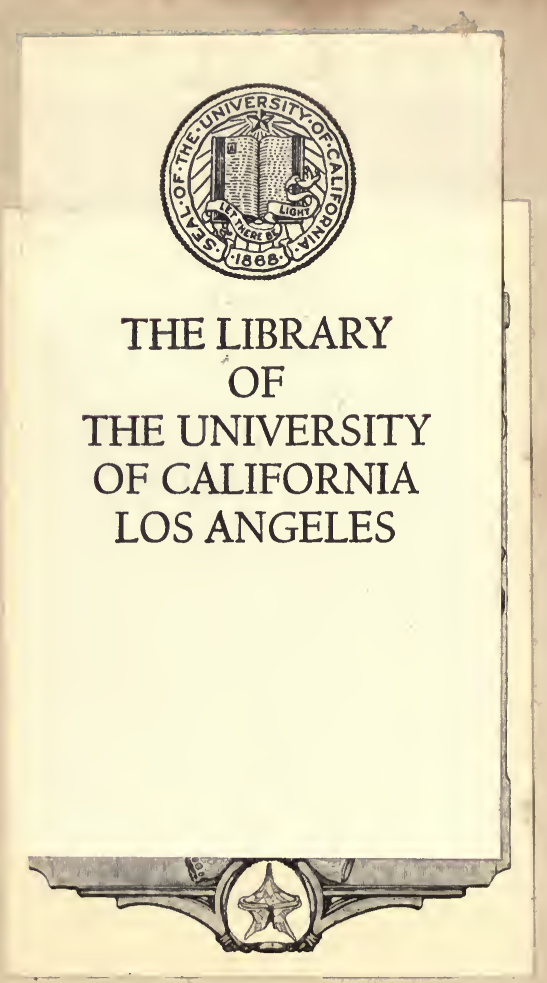




$$
\text { Snuth } \$ 110 \text {, } 10^{\circ}-
$$

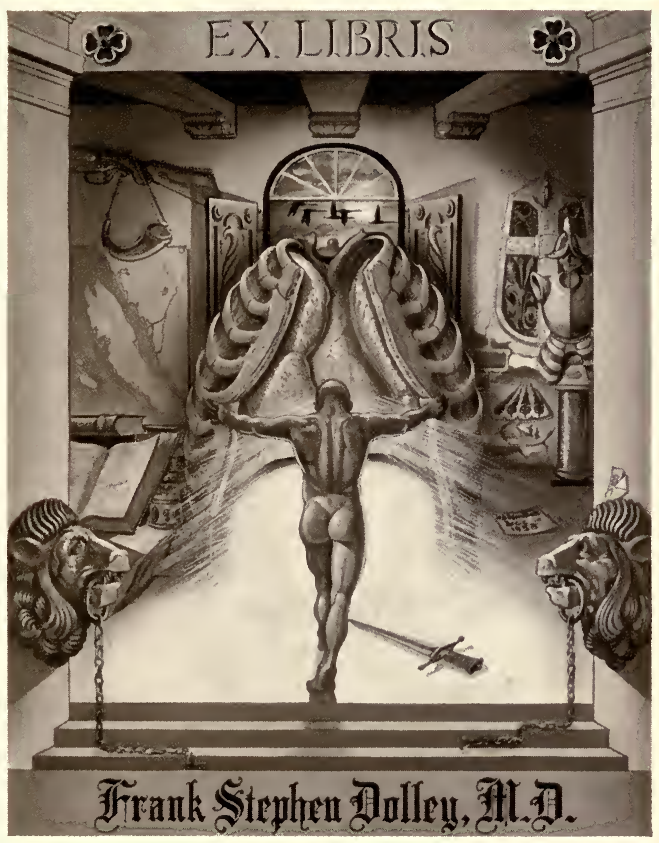


1

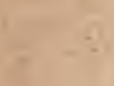

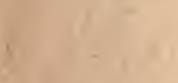

$+\frac{1}{1-}=$

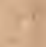

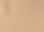

$-$

$+x+1$

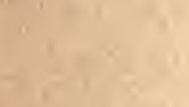

.

$+1$

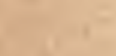

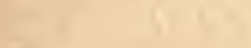<smiles>C1C[C@H]2C[C@H]1C2</smiles>

$x$

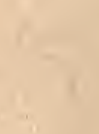

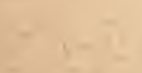
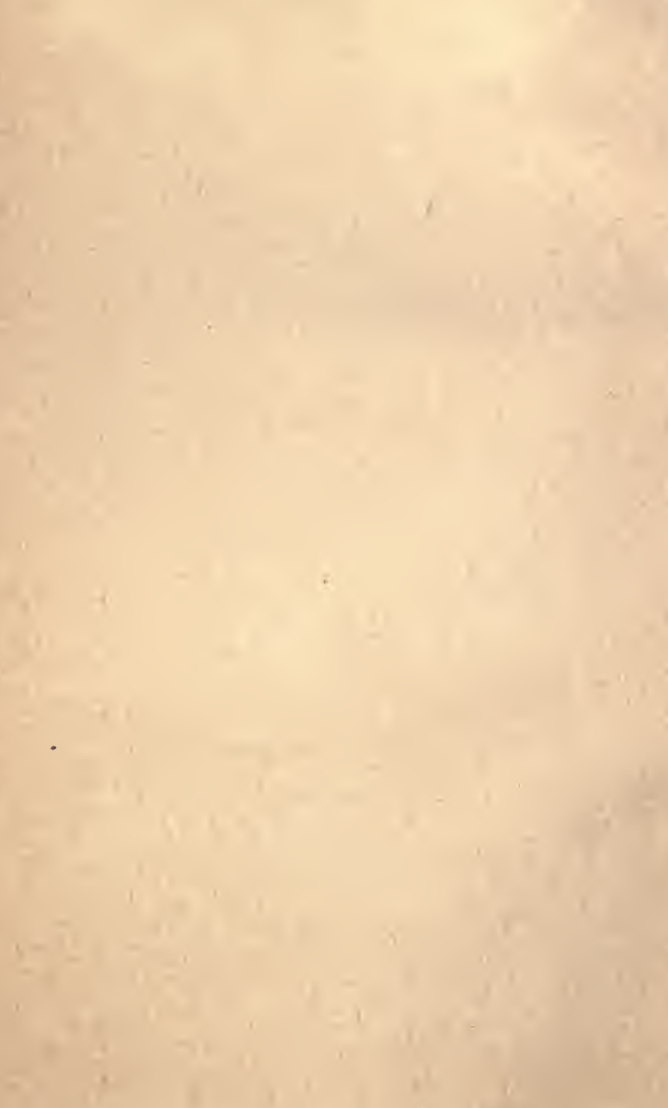

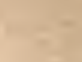





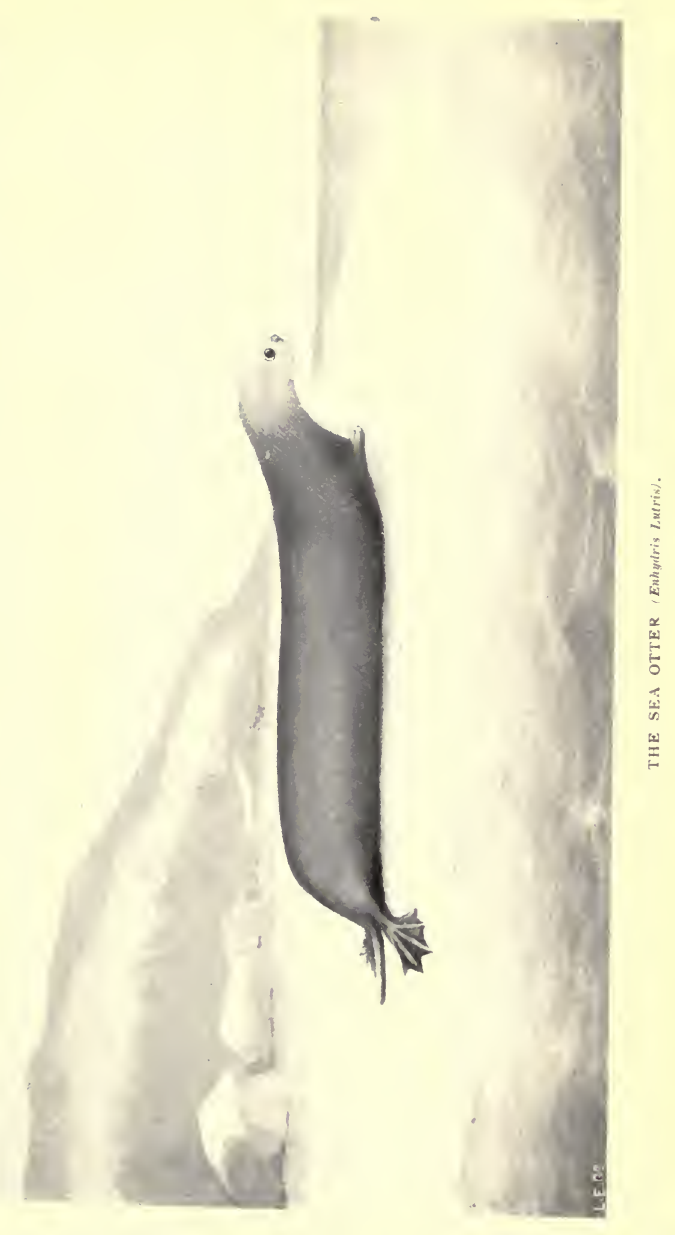




\section{HUNTING THE SEA OTTER.}

BY

Alexander Allan.

Eondon:

HORACE COX,

"FIELD" OFFICE, WINDSOR HOUSE, BREAM'S BUILDINGS, E.C. 



\section{SK \\ 3.41 \\ $\mathrm{S}_{43} \mathrm{~A} 4$}

\section{PREFACE.}

IN the following pages I have endeavoured, from a sporting point of view, to give the reader some account of a hunting cruise among the Kurile Islands in quest of one of the most interesting and, as regards commerce, valuable of all the fur-bearing animals, the sea otter, and to furnish details also as to the method of hunting employed, which will hardly fail to attract attention, as, up to the present time, scarcely a record exists from the pen of an eye-witness. To these will be added such particulars of the haunt; and habits of the animal as time and circumstances allowed me to observe.

Born on the surface of the heaving ocean and cradled in the tempest, the sea otter only makes its home on such storm-swept waters and inhospitable coasts as almost preclude its pursuit by any but the hardy natives, whose lives have been spent amidst the surroundings of those gloomy regions and who are inured to peril and privation.

The great distance from a base of supplies, expensive outfit, and the impossibility of effecting an insurance on the vessel in the event of shipwreck; the total absence, in many cases, of harbours, or, indeed, shelter of any kind, all add to the difficulty of the undertaking, nothing lessened by the shortness of the hunting season and rigorous climate.

During the two or three months that constitute the summer of the North Pacific Islands, four-and-twenty 
hours of fine weather is a matter of rare occurrence. Cold and wet alternate during the greater part of each month, while such stray sunshine as occasionally relieves the dulness, however cheering at the moment, is in reality but a further aggravation of the hunter's discomfort by scorching the skin into a state of tenderness ill-adapted to facing the salt spray and chilling gales that succeed each other so rapidly in these latitudes.

Beyond a short description in some American Government reports, there is no work devoted exclusively to sea otter hunting, and this must be my excuse for venturing into print, both tastes and pursuits having led me more to the contemplation of Nature's works than to the use of the pen and the acquisition of what is demanded in literary composition.

My very best thanks are due to my nephew, Mr. Malcolm H. Beattie, for his care and patience with illustrations and reproduction of sketches.

Alex. Allan. 


\section{CONTENTS.}

\begin{tabular}{|c|c|c|c|c|c|c|c|c|}
\hline & & & & & & & & PAGE \\
\hline CHAPTER & I. & & $\ldots$ & $\cdots$ & $\ldots$ & $\ldots$ & $\ldots$ & I \\
\hline CHAPTER & II. & $\ldots$ & $\ldots$ & $\cdots$ & $\ldots$ & $\cdots$ & $\cdots$ & I 4 \\
\hline CHAPTER & III. . & $\ldots$ & $\ldots$ & $\ldots$ & $\ldots$ & $\ldots$ & $\ldots$ & 28 \\
\hline CHAPTER & IV. & $\ldots$ & $\ldots$ & $\ldots$ & $\ldots$ & $\ldots$ & $\ldots$ & $3^{8}$ \\
\hline CHAPTER & $\mathrm{V}$ & $\ldots$ & $\ldots$ & $\ldots$ & $\ldots$ & $\ldots$ & $\ldots$ & $5 \mathrm{I}$ \\
\hline CHAPTER & VI. & $\cdots$ & $\cdots$ & $\cdots$ & $\ldots$ & $\ldots$ & $\cdots$ & 60 \\
\hline CHAPTER & VII. & $\cdots$ & $\ldots$ & $\ldots$ & $\ldots$ & $\ldots$ & $\cdots$ & 77 \\
\hline CHAPTER & VIII. & $\ldots$ & $\ldots$ & $\ldots$ & $\ldots$ & $\ldots$ & $\cdots$ & 88 \\
\hline CHAPTER & IX. & $\ldots$ & $\ldots$ & $\ldots$ & $\ldots$ & $\ldots$ & $\ldots$ & I 04 \\
\hline CHAPTER & $\mathrm{x}$. & $\cdots$ & $\ldots$ & $\ldots$ & . & $\cdots$ & $\cdots$ & I I 4 \\
\hline CHAPTER & $\mathrm{XI}$. & $\ldots$ & $\ldots$ & $\ldots$ & $\cdots$ & $\ldots$ & $\ldots$ & I 37 \\
\hline CHAPTER & XII. & $\cdots$ & $\ldots$ & $\ldots$ & $\ldots$ & $\ldots$ & $\ldots$ & I 47 \\
\hline CHAPTER & XIII. & $\cdots$ & $\ldots$ & $\cdots$ & $\ldots$ & $\cdots$ & $\cdots$ & I 54 \\
\hline CHAPTER & XIV. & $\cdots$ & $\cdots$ & $\ldots$ & $\ldots$ & $\cdots$ & $\cdots$ & I 63 \\
\hline CHAPTER & $\mathrm{XV}$ & $\ldots$ & $\ldots$ & $\ldots$ & $\ldots$ & $\cdots$ & $\ldots$ & I 74 \\
\hline
\end{tabular}





\section{ILLUSTRATIONS.}

THE SEA OTTER ... $\quad \ldots \quad \ldots \quad \ldots \quad \ldots$ frontispiece ROVER AND THE SEA LION $\ldots$... facing page 44 $\begin{array}{lllllllll}\mathrm{ARCH} & \mathrm{ROCK} & \ldots & \ldots & \ldots & \ldots & , & , & 60\end{array}$

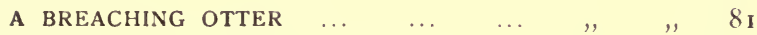
WAITING FOR THE OTTER TO RISE ... ," , IOO NEARING THE END OF THE HUNT ... , , I 20

A FALLING GLASS, OR THE COMING OF $\begin{array}{llllll}\text { THE TYPHOON } & \ldots & \ldots & \ldots & , & ,\end{array}$ AFTER THE TYPHOON - YOKOHAMA

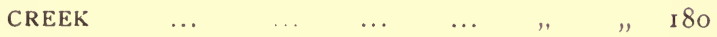





\section{HUNTING THE SEA OTTER.}

\section{$\Longrightarrow$ \\ CHAPTER I.}

TOWARDS the end of the seventeenth century, Feodore Altosov, with a band of pioneering Cossacks, arrived at the end of the Kamschatka Peninsula and became acquainted, for the first time, with the rare and beautiful fur of the sea-otter. Ignorant of their value, and prizing them but little above the skins of hair seals and sea-lions, the natives were only too glad to barter the pelts for such trifles as the Russians possessed. Greed on the one side and fear of the intruders on the other led before long to the practical extermination of the animal along the whole of the Kamschatkan seaboard. A new impulse was given, however, to this profitable trade in 1743 , when the survivors of Veit Behring's second and disastrous voyage landed at Petropaulovski, bringing with them large quantities of otter skins from the hitherto unknown Aleutian and Commander Islands. Two years later Michael Novidoskov pushed boldly into the seas farther north, and, after exploring them for a distance of seven hundred miles in an open boat, beached his primitive bark on the shores of Attoo, the extreme western islet of the Aleutian Chain. Quickly followed by others as hardy and intrepid as himself, the trade carried on in the rude vessels of the time soon assumed such proportions that by 1769 a great part of Alaska had been explored and roughly charted, while in 1799, when the Russian-American Company was incorporated under the authority of the Government of St. Petersburg, there were more than sixty distinct trading 
companies on the Alaskan waters alcne. The consolidation of these companies into one great corporation put an end to the sanguinary quarrels amongst the rival traders, and perhaps lessened somewhat the cruel persecution of the unhappy natives who frequently sought redress for their wrongs in wholesale massacre. By the appointment of a resident governor, invested with almost absolute powers and backed by a military force, the introduction of order into a hitherto lawless and utterly irresponsible community may have been beneficial to the traders and natives, but the object of their pursuit gained no protection in the way of regulation or system in the times and methods of hunting.

Heedless of the inevitable consequences of such a short-sighted policy, already so clearly demonstrated in Kamschatka, and regardless of the palpable diminution in the number of furs obtained, the early hunters contemplated with unconcern the practical extirpation of the source of their wealth, which became simply a matter of time. At length the Company was bankrupt alike in resources and credit, its footsteps being dogged with the results of ignorance and neglect; and the termination of its charter in I 864 was taken advantage of by the Russian Government to put an end both to the Company and the Colony. Finally, in the year following, for the sum of $\$ 7,200,000$, the whole of the Alaskan territory was formally transferred to the United States.

In order to form some idea of the enormous numbers of sea otters which during the early years of discovery existed on these coasts, it may be mentioned that two sailors, Lukannow and Karekov, killed at St. Paul's Island, in the first year of occupation, five thousand, the next year less than one thousand, and six years afterwards not a single otter was seen; and none have appeared since. When Skellikov's party first visited Cook's Inlet they secured three thousand, during the second year two thousand, in the third, only eight hundred; even this diminished number fell the next season 
to six hundred; and since then not a tenth of this number has been taken in any one year. At the first visit made by the Russians to the Gulf of Yahkutat in I794, two thousand sea otters were taken, but the numbers went down so rapidly that within five years of this date less than three hundred rewarded the hunter's toil. In I798 a large party of Russians and Aleuts secured in Sitka Sound and neighbourhood twelve hundred skins; besides these they obtained by trading with the natives fully as many more; and in the spring of $\mathrm{I} 800$ a few American and English vessels came to the same spot, anchored off the small Russian settlement, and traded with the natives for over two thousand skins. The largest number, however, that was exported to the Okhotsk was during the early days of the Company above mentioned, when fifteen thousand skins were brought away from the coast of Alaska.

Owing to the more favourable conditions under which hunting could be prosecuted elsewhere, the whole of the American coast proper, that is from Lower California to Alaska, the extremities of the sea otter's range, has long been abandoned as a profitable hunting ground; such few skins as are still obtained would scarcely amount to one hundred annually; although Sir George Simpson, writing in I $84 \mathrm{I}$, states that since I 8 I 4 the Russians had sent to market the enormous number of eighty thousand sea otter skins from California alone.

So much for the state of affairs under Russian administration. Let us now see what the United States Government have done for the preservation of the sea otter and the protection of the natives who depend upon their barter as the only means of ameliorating the conditions under which they existed.

Mr. W. H. Elliott, the special agent of the Treasury Department, charged with the Government interests in Alaska, writing in 1875 remarks: "Now, during the last season, instead of less than seven hundred skins as obtained by the Russians, our trade has secured not much less than 
four thousand. This immense difference is not due to the fact of there being a proportionate increase of sea otters, but to organisation. Yet the keen competition of our traders will ruin the business in a comparatively short time if some action is not taken by the Government. This can easily be done, and in such a manner as to perpetuate the sea otter and to benefit the natives, who are dependent on its hunting for a living. As matters are now conducted by the hunting parties, the sea otters at Saanach and the Chernobours do not have a day's rest during the whole year. Parties relieve each other in succession, and a continuous warfare is maintained. This persistence is stimulated by the traders, and is rendered still more deadly to the sea otters by the use of rifles of the best make, which, in the hands of the young and ambitious natives, in spite of the warnings of the old men, must result in the extermination of these animals, as no authority exists in the land to prevent it; for these same old men, in order to compete with the riflemen successfully, have to drop their bows, spears, and arrows, and take up fire-arms in selfdefence. So the bad work goes on rapidly, though a majority of the natives and the traders deprecate it."

As the above remarks are embodied in Mr. Elliott's interesting work on Alaska, published in 1886 , it is to be presumed that no steps have been taken in the matter; and the work of extermination goes on unheeded and unchecked.

Such is a brief history of the long-continued course of pursuit, varied occasionally by wholesale slaughter, which has reduced the numbers and diminished the haunts of the sea otter till, at the present time, it is only amidst the stormy waters that gird with barriers of foam the most inaccessible coasts and islands of the North Pacific that it is now to be found, but in such trifling numbers as have relegated its pursuit from one of the most profitable of trades to the region of speculative enterprise. 
It was only after a somewhat extended residence in Japan, and when the writer had been long acquainted with the fact that the habitat of the sea otter covered a stretch from the Kamschatka Peninsula as far south as the Kurile or Northern Japanese Islands, and had from frequent description become familiar with the methods of hunting employed by the natives on both continents, that the subject became personally interesting, leading up as it did to the expedition, an account of which will form the matter of this book. A more intimate knowledge of the American method of hunting, adapted from that of the natives with all the superior advantages of civilisation, the boat and rifle taking the place of the skin "bidarkie," the spear, or the bow, suggested a cruise in these waters. There was the alluring prospect of sport and adventure, leaving little room for the colder but more practical calculation of profits; and the delights of anticipation generally exceed the enjoyment of the object when obtained.

About two years previous to the venture contemplated, a small American whaler, which had been fishing in the Okhotsk, had the misfortune to be wrecked on one of the northern points of the island of Yezo. The captain and those of the crew who were saved were kindly treated by the Japanese, and when sufficiently recovered to bear the journey were dispatched overland to Hakodate, where they took steamer to Yokohama and eventually reached home. This captain, who occasionally varied the occupation of whaling with that of sealing, or sea otter hunting, finding how scarce whales had become in what at one time had been the El Dorado of the whaler, had been quite willing to explore the neighbouring islands and to examine their coasts in the hopes of falling in with a shoal of larger or smaller prey. How far success attended his enterprise is unknown, as little was saved from the wreck, but the information he gave on his landing in Japan was that it had been worth while for him to keep on the ground until the season had become too far advanced for safety, the coast 
an unusually dangerous one, being subject to the most violent and sudden storms, powerful currents, and impenetrable fogs. A few sea otters were found as far south as Skotan, a few round Kunashir, and a sufficient number off Yetorup and Urup to make hunting profitable. A black or silver-grey fox, the most valuable of all the fur-bearing animals, was shot on Skotan, though, unfortunately, in its summer coat. Altogether, in spite of his loss, the prospects were sufficiently good to cause the captain to express his intention of returning the following year with another vessel, solely for the purpose of sea otter hunting; while the description he gave of the manner in which the chase was carried on, together with the united charms of healthful sea life, the excitement of the hunt, and the pleasure of exploration, were alluring in the extreme.

Perhaps the very meagreness of the information obtained, with its unavoidable poverty of detail, leaving so much to the imagination, only added to the fascination of an enterprise which, while promising an amount of sport of a most original description with sufficient danger to give a spice to it, would not improbably result in reimbursement for the heavy outlay demanded. The wish to try the experiment was strengthened by repeated conversations with a friend of kindred tastes; and at length it was determined that, in the event of being able to find a suitable vessel-and this was no mean difficulty - a pioneering expedition should be dispatched on our own account, with as perfect an equipment as the lateness of the season and the difficulties to be surmounted would permit.

We were both of that age when success seems almost a foregone conclusion, and failure appears but as a remote contingency, easily to be warded off even when at hand. So the venture, in which I could not personally participate, owing to a Government appointment which would not terminate till the spring of the following year, was undertaken by my companion, with his usual energy; and a small pilot schooner, the only vessel 
available, was purchased and hastily equipped for the voyage.

Sanguine as we were, it was impossible to be altogether satisfied with the result of our exertions, whether in regard to vessel, crew, or armament. But the resources at our disposal, however limited and inefficient, were the only means by which experience-always difficult and generally costly - was to be obtained. And we parted at length with the understanding that, if even partial success should crown our efforts, the present attempt should be followed up by us both in the ensuing spring in such a manner and with such an outfit as the practical knowledge, which it was expected would be gained, might dictate.

Briefly stated, this voyage was neither pleasant nor profitable. The vessel was not only old but unseaworthy, the skipper incompetent, the crew insubordinate, and both outfit and armament, in the shape of boats and rifles, defective. So leaky was the old schooner that the pumps were seldom at rest, and before a quarter of the distance to the hunting ground had been completed both masts went by the board during a sudden squall off Scindai Bay. This caused a delay of over two months, and when eventually the scene of operations was reached, the lateness of the season prevented anything beyond the chance of a partial repayment of the expenses incurred; in fact, nothing but the indomitable energy and perseverance of my active partner, Captain Snow, prevented the whole affair from being a complete failure. It had been the original intention to remain as late in the winter as possible, but the rotten state of the old craft made it only too evident that she was illprepared to face the furious blasts of a northern autumn.

As the season advanced, chains had to be bound round her to keep the hull from going to pieces; battens were nailed over the more open seams to keep the water out; so - thankful to reach the little fishing village and harbour of Nemoro, situated at the northern end of the Island of Yezo-Snow ran the old hulk ashore and burned her. 
Fortunately, the Japanese Governor was very friendly disposed, and generously offered a godown, or fireproof building, for the storage of what was preserved, Snow stating his intention to return for them in another vessel. The iron knees with which the old schooner had been built, and to obtain which she had been burned, the Governor promised with many declarations of good faith to forward by junk to Hakodate at the earliest opportunity, and so, all arrangements having been completed, inventories made, and receipts obtained, Captain Snow presented the Governor with a'new breach-loader which he had taken a great fancy to, and leaving Nemoro, after a journey of five hundred miles along the seaboard, occupying about twenty-six days and mostly performed on horseback, captain and crew arrived safely at Hakodate.

Snow lost no time in communicating with me, giving full particulars of the voyage, mishaps, and ultimate disaster, adding that he had nearly paid expenses by the skins taken, and, being sanguine of success with a more suitable vessel and crew, expressed his determination of getting such a craft put in hand without delay, so as to be ready by the following spring. To his urgent request that he might be joined by me in the new expedition my assent was readily given.

The shipbuilding interest in Hakodate was, and it is still to be hoped is, represented by an Englishman, $\mathrm{Mr}$. Thompson, equally well known for geniality, kindness, and generosity; a Sunderland man, moreover, whose family had been for generations shipbuilders, his knowledge and mechanical skill eminently qualified him to execute the commission with the strictest attention to the minutest detail. In the hope that this may some day meet the eye of friend Thompson, this opportunity is gladly taken of repeating once more our thanks, with the same sincerity that they were tendered when we parted, for the many acts of kindness and hospitality received by us all at the hands of himself and his partner, Mr. Bewick. 
So the Snowdrop was commenced, and shortly afterwards Snow returned to Yokohama.

To hunt the sea otter properly three boats are required, each carrying four hands; two to row, one with a paddle, to steer, and one to shoot. The first three, it was intended, should be Japanese, the last necessarily a European or American. Snow and myself would each take a boat, therefore another comrade was required. Fortunately, a young Englishman was soon found as third hunter; he possessed a captain's certificate in the American mercantile marine; our new associate could thus discharge the double functions of hunter and skipper, but his certiticate necessitated our sailing under the stars and stripes. This was no disadvantage, for America was represented at that time by a very able and energetic minister, whose recall later on through the exigencies of political parties was much regretted by the community, as he had so zealously watched over and protected their interests and policy. Perhaps the most important part of all, that of ship-keeper, so called from his having to keep, or work, the vessel, as the case might be, while the boats and most of the crew were away hunting, was to be filled by the same man who had accompanied Snow before. In this we were exceptionally fortunate, for Mr. Baker, a Jerseyman, held a first mate's certificate, and was, moreover, like most 'Channel Islanders, a thorough seaman, full of resources as a sailor should be, sober, active, and capital company. His services from first to last were invaluable.

On Sunday, April Igth, with a perfect cargo of guns, rifles, ammunitions, and stores of all kinds, we embarked for Hakodate in an old P. \& O. steamer which had been bought and re-christened by the Japanese. Our skipper soon discovered, to his disgust, that she was completely manned and commanded by Japanese-rather an unusual thing in those days, it being the rule to have at least a European or American captain and engineer. As he seemed much put out on this point, we proposed that he 
should on no account leave the bridge, remarking casually that it would only be a matter of three or four days. But the skipper, who had thrown up a comfortable appointment on shore to accompany us, seemed to view it in a different light. A compromise was, however, effected by which he was to offer his services to the Japanese captain, remaining on deck as much as possible, especially at night; while wc promised very solemnly to keep him on the alert in the event of danger, or when the drowsy god proved too much for weak human nature. It need hardly be said that this promise was religiously kept for the next three days by means of alarming intelligence of stormy skies, breakers ahead, and other imaginary perils, whenever the unfortunate skipper lay down - a relaxation which, having nothing to do, he often indulged in. He invariably declared, on being awakened, that he had just come off deck.

At ten o'clock on the fourth day we were abreast of Tchoochee, an extensive fishing town, backed with a large blunt-topped hill completely covered with pines. The coastline in the immediate vicinity was fringed with hills more or less precipitious which rose to a height apparently about three hundred feet, their outline was pretty regular till they terminated in perpendicular cliffs. The Lighthouse of Boie indicated to vessels arriving the dangerous strand. At three on the fifth day we were off Scindai Bay, the scene of Snow's first disaster. Here the scenery was very beautiful, the coast being deeply indented, the mountains higher and splendidly timbered to their very summits. It is here that the wonderful lake or inlet studded with a thousand islands and so frequently depicted in Japanese Kakimonos, though never yet explored by any but the natives, is said to be situated.

At seven o'clock on the sixth day, a Wednesday, we had passed Cape Shiriya, the Whale Back, and the Rattler rock, the last so-called after one of our vessels wrecked on it. At noon, after a calm, uneventful passage, we dropped anchor in the beautiful, land-locked bay of Hakodate; the 
air was cold but clear and invigorating, the surrounding hills being still covered with a mantle of snow. For the next fortnight we were all busily occupied, helping Baker with the sails and rigging of the Snowdrop which was already afloat, having been launched a week prior to our arrival. On May 7 th we were ready to sail, but, pending the long-promised delivery of our "papers" from the Japanese authorities, we took a short trial cruise round the bay to test our vessel and crew. Everything proved as satisfactory as could be expected, only more so, as the skipper observed. Before commencing our voyage, it will be as well, perhaps, to give some description of the ship and her crew.

Built entirely by Japanese carpenters under the constant supervision of Thompson-the native dikesan being quite as clever at "scamping" his work as his more civilised brother-the Snowdrop was a fore and aft schooner with pole masts and of about the following dimensions :-

$\begin{array}{lrrrrrrrl}\text { Tonnage } \ldots & \ldots & \ldots & \ldots & \ldots & \ldots & 62 \text { tons B.M. } \\ \text { Length over all } \ldots & \ldots & \ldots & \ldots & \ldots & 70 \text { feet. } \\ \text { Length of water line } & \ldots & \ldots & \ldots & 60 & " \\ \text { Beam } \ldots & \ldots & \ldots & \ldots & \ldots & \ldots & \ldots & \text { 18 } & , \\ \text { Draught, loaded... } & \ldots & \ldots & \ldots & \ldots & 5 & ,\end{array}$

The knees were all of solid, native-grown oak, requiring but a slight trimming with the axe before being put in their places. This abnormal angularity is owing to the fierceness of the blasts that, at all times of the year, but especially in winter, sweep over them with resistless force. Sheltered and upheld by the deep snow, they struggle upward gnarled and lichen covered; but here their course is checked, and frequent bending to the storm results, as they grow, in strange and weird shapes and angles.

Although the Governor of Nemoro had repeatedly promised that the iron knees, to obtain which Snow had burned his vessel, should be dispatched as early as possible to Hakodate, they never appeared, and, when a few weeks later we reached that place, they were to be seen exactly as they had been left eight months before. With laudable 
prudence Thompson, after waiting for them a considerable time, had determined to dispense with them altogether, or the expedition would have been delayed an indefinite time ; indeed, entirely abandoned.

A raised poop, about two feet six inches high, extending aft from the mainmast, gave good head room to the cabin and, stopping short at the cabin scuttle, left a large cockpit, in which were the wheel and binnacle. Taken altogether, she was a strong, roomy little craft; her principal weakness, we soon discovered, was a decided tendency to make leeway, consequent on her great beam and light draught; and, though the latter on more than one occasion saved a scrape on the rocks, the uncomfortable fact was always present that, should it come to clawing off a lee shore, our position would be anything but agreeable, and our chances of the smallest.

The difficulties attending the design of a vessel especially adapted for the purposes of sea-otter hunting were, almost of necessity, very great, and will be appreciated when it is remembered how many essential points have to be considered.

Room on deck was required for four boats, three for hunting, and one for such rough work as getting wood and water; these had all to be lashed on deck when not in use; below, storage for eight or ten months' provisions for a large crew, water for all purposes for a month, wood for the store, galley, cabins and magazine, and yet the craft to be sufficiently small to be worked in all kinds of weather by two men and a boy, only one of whom, the ship-keeper, would be a sailor. The crew consisted of nine men supposed to be sailors, a cook, and a cabin boy. All of them were natives, and occupied the fo'castle, the after part of which formed the galley. The hold, with its two large wooden water tanks, spare sails, and stores of all kinds, came next, and was divided from our mess cabin by a sliding door, through which the boy brought our meals. Right aft was Snow's cabin, which was also the magazine, and as he was the only non-smoker of the party he had the distinction of 
reposing on and being surrounded by explosives enough to delight the heart of a dynamitard. The mess cabin was bulk-headed on either side into berths, which, by means of sliding doors, could, if total darkness and certain suffocation were not objected to, be made into cabins also. Indeed, Thompson, with a merry twinkle in his eye, designated them as such, with more polite pretension than truthful regard for reality. The skipper, under the excuse of not being able to see the chronometer properly, got a dead light inserted in the deck; but, as it was placed just over his head and persistently leaked, he had to go to bed in his oilskins, a fact which must have detracted somewhat from its supposed convenience, and the stray sunbeams which found their way through the dim glass were more depressing than cheerful. 


\section{CHAPTER II.}

AT length, after a series of wearisome delays, due either to the ill-will or stupidity of the Japanese Custom House authorities-it was difficult to say which-the skipper, accompanied by the American Consul, managed by threats or guile to get possession of our papers, without which we could not legally clear out of the port; and within an hour afterwards the anchor was weighed and the little Snowdrop, as if in delight at her tardy freedom, spread her white wings to the breeze and gaily threaded her tortuous way through the surrounding junks and sampans. The breeze freshened as we left our anchorage, and by standing well over to the northern shore we soon drew away from under lee of the mountain which protects the other side of the harbour, and on whose slope the town of Hakodate is built. Ere long the wind got steadier, though still too light to please us, and we were abreast of the fort with nearly a mile of offing.

This fort, an ingenious arrangement of mud and stone, which would not have stood a couple of rounds from a big gun, was to us an object of considerable anxiety, for so numerous had been the obtacles thrown in our way by the Japanese authorities-obstacles which even Eastern procrastination would scarcely account for-that we were almost forced to the conclusion that they, for some reason of their own, had determined, if possible, to stop us altogether; or, failing that, to delay us until the season was so far advanced as effectually to mar the success of the expedition. For it must be remembered that the islands for which we were bound were surrounded in winter and early spring by masses of ice, even as late as the month of 
May, while when the September Equinox drew near terrific gales, with their usual accompaniment of fog, swept with relentless fury the rock-bound coasts. The hunting season therefore being necessarily short, every day was precious; and it may be easily understood that, having so far overcome all difficulties and having made a fair start, the prospect of being "brought to" with a round shot across our bows was not an agreeable one, though unfortunately not so improbable as might be imagined. Nor were our suspicions unfounded, as was to be amply demonstrated in the event; but our time was not yet come, and it was only later on that we were to be subjected to much anxiety, danger, and that which, but for our own resolution, would have resulted in inevitable disaster.

We had examined this fort and its primitive armament several times during our forced inactivity, and had determined that when we did sail we would keep well over to the farther shore and let them blaze away till tired. As a precaution, however, our consular friends who had come on board to see us off and take a farewell, caused their respective flags to be hoisted in the boats we were towing, as a mild hint that we were under their protection. Nothing happened to interrupt our progress, and as we had now fairly opened the mouth of the harbour, and as some dark clouds had begun to rise with a squally look, the boats in tow were hauled alongside, and, after a parting glass of petroleum champagne, and many a cordial handshake, our guests dropped over the side, and with a hearty cheer left us to continue our onward course.

We were soon round on the other tack and heading straight out, the wind getting lighter every minute, until, as ill-luck would have it, just as we reached what a railway porter once called the "entrance out," it fell a dead calm; and, with nothing to stem the insetting tide, we drifted steadily back, and finally, about ten o'clock, we were forced to drop anchor under the guns of our objectionable friend (?) the fort. Certainly we might have anchored before 
drifting into such a position, but the water was deep and the bottom rocky, and having only one small anchor and hawser aboard, it was thought more prudent to risk the possible danger from the fort than to incur the chance of losing our anchor. As it liappened, anchors, of which we had the most need, were the very things in which we were most deficient; three, at least, were absolutely necessary for such a cruise as ours. For the islands which were our destination were without a single harbour, or even fairlysheltered bay. The only chart we possessed gave but a bare outline of the coast, and that, as we subsequently discovered, not always correct. The terrific gusts of wind which literally tore down the ravines or "woolled" down the mountain sides silenced the roar of the surf, frequently lifted the spray in steaming clouds to dash it in blinding showers upon the deck; under these circumstances, the possession of good holding gear was a question of the greatest importance. To be blown off the land at such a time meant groping one's way for days, perhaps weeks, helpless and powerless amidst fogs and currents, without counting loss of time. On the other hand, those days are exceptional indeed, even during the prevalence of the calmest weather, when a thousand leagues of ocean, restless and unrestrained, forget to fret against its island barriers and hurl with sullen grandeur its giant combers on their shores. We found it difficult to procure anything in the way of anchors suitable to so small a craft. The one we had was bought in Yokohama, and brought with us among our stores and personal baggage in the steamer. It would have been folly to start so lightly equipped in many respects, had it not been that we expected to take in many more stores, anchors included, at a point farther on in our course, and just previous to encountering the more dangerous navigation of the hunting grounds.

The first night passed quietly, some amusement being caused, when we turned in, by the discovery that our friends, before leaving, had sewn up the legs. and arms of our 
pyjamas. Each one thinking that the joke had been perpetrated on himself alone kept silence, until the skipper let the cat out of the bag by remarking, in a very matterof-fact tone, that having now fairly left port, he reckoned he would commence sleeping with his clothes on. Next morning, by five o'clock, the anchor was up, but the wind was light and variable, so that it was fairly noon before we could round Cape Blunt, or Red Bluff as it is also called, and get into the Straits of Tsugaru. As soon as this was done we could head southwards, with a strong current in our favour. A spanking breeze was blowing outside, and by two o'clock we were abreast of Cape Yesan.

While Snow was giving out some tinned meats for dinner, it was proposed that there should be a pudding of some kind-not that anyone cared for such a thing, of course, but merely to see how far we could trust in the hitherto untried capabilities of our cook. This worthy individual had a plump, sleek appearance as far as his face was concerned, though its beauty was considerably marred by a most pronounced squint, and his spindle legs, clothed in tight-fitting blue continuations, gave him very much the appearance of a paddibird. After a short, but impressive, speech as to how apple pudding was made in civilised communities, Snow handed him a tin of Canadian apples, covered outside with a gorgeous representation of the redcheeked fruit within. Assuring us that apple pudding was a thing of nought before his skill, he received with a low bow the materials for the famous delicacy. The whole proceeding reminded us of some chairman of a workhouse committee receiving from a group of admiring tradesmen a testimonial of esteem and regard for one who, while lining his own pockets well, had not denied to them corresponding advantages. The scene was impressive, and, as all subsequently agreed, the best part of the pudding. Whether it was through being our first dinner on board, or because of the haze of uncertainty that surrounded it, the fact remains that more than usual 
interest centered in that meal; everything passed off well till the pudding appeared.

"By Jove! boys, it looks first-rate. I always thought he was not such a darned fool as he looks, although I never saw a man yet that squinted who was not either a knave or a fool," exclaimed the skipper.

"You bet I took very good care of that before I took him," remarked the master.

But when the deceptive pudding was cut, the revulsion of feeling was terrible, for not a vestige of apple could be seen; in fact, it was a suet pudding pure and simple.

"The beggar has eaten the apples," said Snow.

"He daren't," answered the mate, with a significant glance at his sea-boots.

"Well, then, where are they?" rejoined Snow. "He cannot have forgotten them. Look for yourselves; I have given it up."

This led to a more minute examination, which disclosed the fact that the idiot had mixed both dough and apples into one solid mass before submitting the concrete to the pan. The mate was much disgusted, the rest of us highly diverted. The delinquent was summoned, and stood trembling before the wreck of his handiwork, his weather eye rolled towards the companion ladder. After a good rowing for his conceit and for spoiling our dinner, the punishment decreed was that he should eat it. But this was too much. Lickings he might be accustomed to, but to swallow a "foreign devil's" pudding was too awful, and with a yell of terror he sprang like a monkey up the ladder, materially assisted by one of Baker's sea-boots-in case he might slip. Oki, our boatswain, who had acquired certain expletives, which gave to his mangled pidgin English a warmth of tone and colouring which would otherwise have been wanting, gave a graphic account of the cook's sudden appearance through the scuttle.

"I makee lookee topside deck, speakee wheelman, makee look see cookee, all same fly. Cabin plenty bobbery. Son 
of a gun, I thinkee. No can savey that pidgin cookee no makee sit down, all same sea-boot. I think all same fooro (fool)."

The natural tendency of man to strong language, in order to ease the expression of his more violent emotions, is universally illustrated, and has been even justified, by the pious Scotchwoman, who, when reproached with the fact of her son being too strongly addicted to swearing, replied that, "There was nae doubt that Jock was a awfu' swearer, but who could deny that it was a great set-aff to conversation."

Cape Yesan terminates in a large volcanic mountain, which, rising sheer from the sea to a height of 2300 feet, stood out in bold relief against the hard northern sky. In the calm, clear air its blunt and somewhat rounded summit was enveloped in a mist of steam and sulphurous vapour. Frequent landslips revealed here and there the red sandstone rock, contrasting vividly with the snow-like appearance of the beds of sulphur with which its upper half is covered.

In the still air, great columns of vapour rose like genii from the innumerable boiling springs which studded its base and shoulders, while every now and then from some unseen crevice a cloud of molten sulphur, impelled by the pent-up steam beneath, was hurled upwards with the noise of artillery. The lively imagery of Eastern story was witnessed in Nature's forces ; the mind, so retentive of early impressions, recalled without effort that delightful story of boyhood's days, "The Fisherman and the Genii."

It might well have been upon some kindred shore to this, where Nature in all her wildness and mystery reigned supreme, some tiny sandy bay, such as we can just see breaking the stern grandeur of the rock-bound coast, that the lonely fisherman, with his primitive net, dragged from the crystal depths the earthen jar. He breaks the magic seal, and lo! with a terrible report, where all was clear and still before, there rises a cloud of blinding vapour, which gradually assumes the form of the genii of the mountain. 
In the Plutonic chain that skirts the eastern shores of Asia, passes southwards through the Philippines and Moluccas, joins the Southern Belt, and finally traverses Sumatra and Java, the Japanese Islands may be said to take the most prominent place for active volcanos and seismic disturbances, and although, since the terrible earthquake of 1855 which destroyed the greater part of Tokio, and brought death to tens of thousands of people, there has been nothing approaching catastrophe, almost every mountain may be said to be of volcanic origin, while no fewer than fifty are in a state of intermittent activity. Waves of earth motion numbering hundreds within a single month have been observed and recorded by the Seismological Society. In the south especially the earth not unfrequently opens in cracks and chasms, making the natives fly to the bamboo groves under the belief that the thickly interlacing roots would so bind the surface of the ground as to prevent its disruption. It is impossible to imagine a more disagreeable and eerie sensation, or one more suggestive of the uncanny, than to be suddenly awakened on one of those sultry nights which usually precede those visitations, by the violent rattling of every door and window in the house, to be succeeded by one, two, or more sickening heaves, while every beam and rafter cracks and groans like a soul in agony. In Japan an old legend ascribes earthquakes to the movements of a creature with an oblong, scaly body, ten legs, feet like a spider's, and the head of a dragon Jishinmushi, or earthquake insect; on its head rests the Kaname rock, with which it is the duty of the Kami or deity of the district to keep the beast as quiet as possible.

To continue the narrative. The breeze which had been very light freshened somewhat about eight o'clock, and being right aft enabled us, running wind and wing, to make good way until midnight, when it became so brisk that we were compelled, not a moment before it was absolutely necessary, to take in a couple of reefs. About three in the morning the skipper, keeping watch on deck, startled all the ship's 
company by the cry of "man overboard." In a moment we were on deck, and a boat lowered. The vessel was already hove to, if such it could be called, when without a breath of wind, and regardless of her helm, she lay tossing and turning like a log on the water in a heavy cross-sea and "tide-rip." The skipper, who had hastily taken the bearings the moment he missed the man, pointed out the direction in which to search, but though the boat cruised about for a couple of hours, in the dim uncertain light of the early morning, and every ear was intent to catch some responsive cry to the repeated shouts from the boat to guide and cheer the unfortunate swimmer, if yet above the waves, nothing more was ever seen or heard of our poor little messmate "Dandy Jim."

It appeared subsequently from the skipper's account that after running steadily until nearly three o'clock, the wind suddenly died completely away, leaving the schooner pitching and tossing in an ugly "tide-rip." After waiting a short time to make sure that it was not a momentary lull to be followed by an increased blow, a very frequent occurrence on these coasts, he summoned the watch to shake out the reefs, and it was while doing this, though specially cautioned to be careful, that poor little Jim must have been pitched by a sudden jerk into the sea. The entry in the log is as follows :- "Dandy Jim, while casting off reef earing at end of main boom, jerked overboard. Tide-rip, heavy sea, no wind. Boat lowered, no swimmer, heavily clad, lost." Apart from every other consideration, the loss of one of our best hands was a serious matter. Only the boatswain and himself had, of all our crew, ever served aboard a European vessel, and consequently knew something of their duties. It would be impossible now to replace him, and our crew before this had only just been sufficient. Poor fellow ! his sufferings must soon have been over in a such a heavy sea. There were many sharks about; indeed, we had seen a considerable number on the preceding day. But in spite of the many stories told of the cruel ferocity of these monsters, 
not one of us had ever come across a really well authenticated instance of a swimmer having been seized, although collectively we had been pretty nearly all over the world. In fine, sailors' superstition, his own repulsive looks and dogged perseverance in following ships, though not more so than that of gulls or "chickens," have given to the shark that proverbial bad name which it is sought to perpetuate by maligning him on all available opportunities. In all probability, as its habits become better known and studied, the true character of the shark will be found to assimilate with that of scavenger vulture rather than the swooping eagle.

After an unmerciful amount of tumbling and tossing, by some unaccountable means, possibly a local current, we got outside the influence of the tide-rip and into smoother water, drifting along, fortunately on our course, a few miles distant from the shore.

The coast, which at Cape Yesan, terminates in a mass of mountains all more or less volcanic, turns abruptly, runs in a northerly direction for about fifty miles, then, breaking away to the north-east, forms Volcano Bay, and running back in an almost straight line to the south-east, is brought up in a huge mountain bold outline, 3500 feet high, at Cape Yerimo. The cliffs rising from the water which washed the base of the chain, presented an even face, unbroken by either dip or gulley; there was no sign of any stream discharging into the bay, although there are said to be several farther on. The country was well wooded, but there was not a trace of a human dwelling or even a boat. Nothing broke the bright surface of the water save the fin of an occasional shark, a melancholy guillemot, or a few gulls with their jaunty, high-pitched stems, looking like miniature caravels on the lake-like sea.

As we drew abreast of Cape Yerimo, the scene became more animated, for we found the fur seal in large numbers. The extensive groups of half-submerged rocks, many of large size, which form a reef stretching more than a mile 
into the sea, evidently afforded a favourable place for refuge or repose. The food supply is here doubtless as plentiful as varied, on account of the different temperatures of the neighbouring waters. For the equatorial current of about sixty degrees passes into the Sea of Japan, after rushing through the Straits of Tsugaru at the rate of four or five knots, and still keeps its easterly course till it meets off this cape the colder Arctic current of thirty-six degrees coming from Behring Straits.

With a bright sun and clear sky overhead, a smooth and glassy sea around, it was just the time to observe with accuracy anything strange or unusual in the water; in fact, it only wanted the appearance of that periodical mystery, the sea-serpent, to put a finishing touch to the scene. And we were not to be disappointed; for after having been busy all the morning cutting out a cleat and rigging a reef pennant to provide us with the means of reefing the mainsail from the deck, and thus to prevent the chance of any such mishap as had recently befallen, we had all turned in, as we stood, for a few hours' sleep, when I was aroused by the skipper calling me on deck and to bring a rifle quickly.

Hastily snatching one from the rack, I was soon by his side, and he pointed out right ahead and about two hundred yards off, what to all appearance was an enormous serpent lying coiled up asleep on the water. It certainly seemed impossible to mistake it for anything else, for every fold could be distinctly seen, several of them standing out so high above the surface of the water that light was plainly visible beneath.

I could not help exclaiming, "By Jove, it is a serpent."

"Wal," rejoined the skipper, not wishing to compromise himself, " it certainly looks a sort of curio; but wait a bit till we get a little nearer, and then plug him-I guess that will make him clar up a bit;" and sure enough, in another couple of minutes, both the mystery and the serpent did "clar up." For just as the rifle was at my shoulder, the mainsail gave a slight rustle, and in a moment, with a 
sounding flap, flap, our kraken vanished, to appear the next moment in the shape of a dozen large fur seals, craning their heads and necks out of the water, gazing at us in astonishment with their great round eyes. One of them, a fine big fellow, received the contents of my rifle, but, unfortunately, sank before a boat could be lowered. This was the first time we had seen the fur seal sleeping; they were all in a row, and seemed to be lying on their sides with the flippers bent back to the head, assuming very much the position of the homely whiting when served for breakfast. The body curved, and the flippers, resting on the head, showed daylight underneath, giving the exact representation of a huge, basking snake.

Both the skipper and myself came to the conclusion that, though incredulous as to the existence of the renowned kraken, if we had not seen the dénouement we should hereafter have been inclined to agree with Sir Roger de Coverley, "that a good deal could be said on both sides."

We saw no sea lions (Eumetopias stelleri), although there is generally a colony of these monsters on the reef.

Yerimo seems to be the western limit of both the fur seal and sea lion, a young one of the former kind has been killed in Hakodate harbour earlier in the year, but whether, as is probable, it came down from the Okhotsk or found its way from Yerimo round Cape Yesan it is impossible to say. On account of the interest attaching to the subject, no excuse may be needed for introducing here a short account of the fur seal industry, taken from the final report on the tenth census of the United States, giving, as it does, not only a description of the capture of the animal, but of the different processes through which each skin has to pass before it is fit for wear.

"The killing of fur seals is accomplished entirely on land, and the able-bodied Aleuts who are settled upon the two islands of St. Paul and St. George are, by the terms of the agreement between them and the lessees, the only individuals permitted to kill and skin the seals. For this labour 
they are paid at the rate of $\mathrm{i} s .8 d$. per animal. The work connected with the killing of the annual quota of fur seals may be divided into two distinct features, the separation of the seals of a certain age and size from the main body and their removal to the killing ground, and the selection among the select and killing and skinning the same. It is the habit of the young male seals, up to the age of four years, to lie near the sea-shore, and the experienced natives manage to crawl in between them and the sea, and gradually drive them inland in divisions of from two thousand to three thousand. It is unsafe to drive the seals more than five or six miles in any one day, as they easily become overheated, and the skins are thereby injured. When night comes on the driving ceases, and sentries are posted round each division to prevent the animals from straying during the night, occasional whistling being sufficient to keep them together. In the morning, if the weather be favourable, the driving is continued until the killing ground is reached, where the victims are allowed to rest over-night under guard; and finally, as early as possible in the morning, the sealers appear with their clubs, when again small parties of twenty or thirty seals are separated from their fellows, surrounded by the sealers, and the slaughter commences. Even at this last moment another selection is made, and any animal appearing to the eye of the Aleut to be either above or below the specified age is left untouched and allowed to go on its way to the shore. The men with clubs proceed from one group to another, immediately followed by the men with the knives, who stab each stunned seal to the heart to secure its immediate death. These men are in turn followed by the skinners, who with great rapidity divest the bodies of their valuable covering, leaving, however, the head and flippers intact. A few paces behind the skinners come carts drawn by mules, into which the skins are rapidly thrown and carried away. The wives and daughters of the sealers linger in the rear of the death-dealing column, taking away the blubber, which they carry on their heads, 
the oil dripping down their faces and over their garments. The skins, yet warm from the body, are discharged into capacious salt-houses, and salted down for the time being. This treatment is continued for some time, and after the application of heavy pressure they are finally tied into bundles of two skins, securely strapped, and are then ready for shipment.

"The following is the process by which these skins are prepared and dressed in New York. When the skins are received by the furriers, in the salt, the latter is washed off, and the fat removed from the inside with a knife, great care being taken that no cut or uneven places are made in the pelt. The skins are next thoroughly cleansed by being stretched upon beams and dried. After the drying process they are soaked in water, and thoroughly washed with soap. After this the fur is washed again, the pelt being kept moist, and the workmen pull out the long hair with the assistance of a dull knife. This operation, a very delicate one, is repeated several times, until nothing but the soft fur remains. The skins are then dried again, and moistened on the pelt side, and shaved until a firm, even surface is obtained. Then follows the process, a slow and tedious one, of working, drying, and softening the skins by treading them with bare feet in a hogshead, with fine sawdust to absorb the grease. In dyeing, the liquid is put on with a brush, the points of standing fur being carefully covered. The skin is then pulled, so as to make the points touch each other for some little time, and partially dried. The dry dye is removed and another coat applied, and the same process is repeated a number of times. A few of the coats of dye are put on heavily, pressed down to the edge of the fur, from eight to twelve coats producing a good colour. The skins are then washed again, and cleansed with sawdust."

In the neighbourhood of Yerimo the fur seals were exceedingly numerous; in whatever direction the eye was turned they might be observed, sometimes singly or in 
pairs, but generally in small groups, swimming about or diving, but more frequently "breaching," as it is called. This consists in throwing themselves completely out of water every few yards while going at racing speed. It was certainly most curious and interesting to see a string of about a dozen at equal distances chasing each other rapidly, all springing at the same moment, the bright sun shining upon their glistening skins, then cleaving the water head foremost, without the slightest splash, only to reappear and go through the same performance farther on, frequently keeping this up for a long time, just as if they were playing at "follow the leader." The porpoise frequently resorts to this means of what seems a more rapid progression, and on a bright day a school of several hundreds progressing in this curious manner offers an attractive spectacle, the eye being frequently directed to them by the glinting of the sun upon their sleek skins as they spring through the air. We afterwards found this to be a favourite movement both of the fur seal and sea-otter when hard pressed. 


\section{CHAPTER III.}

Anxious as we were to get on, we would fain have lingered for a few days to get some seal skins, but the inhospitable shore was absolutely without shelter of any kind. What a delightful cruise could be made along this comparatively unknown coast in a good steam yacht, which, regardless of wind or tide, could stand out to sea when necessary, for the reefs are covered and the waters abounded with sea-lions, fur and hair seals, the latter of several varieties, while on the land are bears, great quantities of deer (Cervus shika), almost identical with our red deer, of large size and carrying splendid heads, probably the Nigou or Japanese chamois (Antelope Krupi), or some kindred species in the mountains; trout in the streams; swans, geese, and ducks of many varieties in the lakes and lagoons.

In the evening of the fourth day of our cruise a breeze sprang up and we were soon running along the coast at about five knots, but morning found us again in a dead calm. It had been blowing hard enough outside, for in the trough of the great glassy seas, which seemed too lazy to break, we rolled incessantly, the gunwale almost under water, till even Baker, who had been at sea, man and boy, for forty years, was forced to pay toll to "Father Neptune." The reefs began to show marks on the canvas, and both sails and chafing gear suffered considerably, and all the time we were drifting nearer the shore. This state of things lasted all day, till about the same time the preceding evening, when, just as orders had been given to "out boats" and tow the ship off, Æolus, in sheer pity, sent us a nice steady breeze 
which enabled us, after getting a good offing, to resume our true north-east course, running five knots. Unfortunately, this only continued for four hours, when it fell dead calm again, a strong current setting us to the eastward.

All next day was dull and misty, with occasional rain, a striking contrast to the lovely weather we had had hitherto. When Snow and I relieved the skipper at four o'clock in the morning, a strong north-easterley wind was blowing, with rain and fog. So we ran into fifty fathoms of water to get out of the current, and waited for the weather to clear up, which it did in the evening, when we sighted Cape Temposti. But the fog no sooner lifted than the wind went down, and we dropped anchor about two miles from the shore in twenty fathoms of water. The next two days were warm and beautiful, but without a breath of wind, and there was nothing for it but to remain where we were. Ourmen enjoyed this sort of thing immensely; even at busy times they were seldom trusted to do much.

The Japanese, though good enough boatmen, are not naturally sailors, like the Malays or Kanakas.

Sidney Smith accuses Englishmen of always wanting to kill something on a fine day. Without going so far as that, though, considering that we were on a hunting expedition, his remark might seem particularly applicable to us, an Englishman is certainly miserable without something to do. But how our men luxuriated in what the skipper called "a good, solid 'loaf,'" lying sprawling about on the deck, half naked, while the sun dried their upper garments-half toga, half dressing-gown-which they dignified by the name of "kimono!" They giggled and chattered away in their language, soft as Italian, fluently enough to have elicited the approbation of the good Scotch baillie who, on his return from the Continent, expressed his greatest source of wonderment to have been to hear the children jabbering awa' at their French "for a' the warld like our ain bairns their mither tongue." The coast here was very beautiful; a background of mountains, apparently 
about 2000 feet high, broke up rapidly into hills as they neared the water, down to which they sloped somewhat abruptly. In many places huge landslips, the result of frost and the undermining action of the waves, formed cliffs, leaving the half-submerged rocks piled up in endless variety and confusion beneath, many of them on end like huge needles, reminding one forcibly of the Quiraing in Skye. The country was well wooded with stunted birch and fir, the former mostly white-looking and dead, through having their bark stripped off by the Einos for covering their houses, and for torches and other purposes. The fibre of this bark is woven into a coarse kind of cloth, and twisted into the string of which their nets are composed.

While here we observed a number of curious marine creatures, which had before attracted our attention when lying in Hakodate Harbour ; there they were more plentiful, but we were too busy to notice them much. They might well be termed "marine millepeds," they looked somewhat like animated ribbons. The largest we measured was 14 inches long and $\mathrm{I}$ inch broad, colour a reddish-brown, lighter underneath, shape like an exaggerated milleped, their movements when swimming, very slightly undulating, were evidently performed by the short legs, many hundreds in number, which lined both sides of the body like a delicate fringe. Head and body were all in one; in fact, it was difficult to say whether it had a head at all, and if so, at which end it was. What we took for it, on account of being a little broader than the rest of the body, had the appearance of a half-closed anemone. They were all swimming on or near the surface of the water, which was here 20 fathoms deep, with fine, sandy bottom. We tried in vain for a long time to fish up one with a boat-hook, but they invariably broke in halves, dyeing the water a milky-white. At length we had recourse to a bucket, which proved more successful, and we obtained the individual that enabled us to give the foregoing description. 
Akkeshi Bay runs inland about five miles, with a nearly corresponding breadth, and it is the only harbour properly so-called on the east coast of Yezo. But though there is plenty of water and the holding good, it is very much exposed, east and south-east winds sending in sometimes a heavy rolling sea. A small colony of Japanese, with about three or four times their number of Einos, live, or rather exist, here by collecting edible seaweed, deer's horns, oil, and fish manure, all of which are sent to the south by native trading junks, and these call every summer. The mountains are here broken up into a succession of low hills and ravines, densely wooded with stunted birch, oak, and alder; at the head of the bay is a large lagoon, which, later on in the season, is covered with swans, geese, and duck, besides large flocks of waders. The Japanese shut themselves up in the winter in these cold regions, to appear in the spring with their faces blanched white with the poisonous fumes of their charcoal fires.

Feeding almost exclusively on rice, fish, and vegetables, they are ill-adapted to stand cold, and it is surprising what a small amount of blood they have in their bodies. The writer remembers to have seen a native have his foot cut off, from whom scarcely a teaspoonful of blood escaped. On another occasion, when leaving home early one winter morning for a day's shooting, he had stumbled over the body of an unfortunate jinrickshaw coolie, which lay at his threshold, where he had evidently been cut down by his irate and drunken passenger. This man, though killed by a terrible stab in the breast, had scarcely dyed with his blood the snow on which he lay.

Formerly, the Japanese possessed the island of Saghalien, but the cold was always too great in winter to permit of any successful attempt at colonisation, but a short time before our voyage, being alarmed by Russian claims, they had sent up several families to make another attempt, and Baker had been mate of the steamer that was commissioned to call in the ensuing spring to see how they had fared. 
After passing over a mile of frozen sea, which separated the exploring party from the land, they reached the unfortunate settlers, who were found in a most deplorable condition. There was scarcely one of them who had not suffered more or less severely from frost bite, many having lost both feet and hands. The Russians now claim the entire island, and would probably annex the Kuriles if a pretext occurred.

The Einos, though looked down upon by the Japanese, are much hardier than they, and hunt the deer in the deep snow, killing large numbers with their primitive bows and bone-tipped arrows. The flesh of these animals forms their principal winter diet; the skins are converted into robes and the horns are exported to be ground up for a medicine, in the efficiency of which both Japanese and Chinese place great faith.

Our progress still continued to be miserably slow, the wind being both light and unsteady, never more than sufficient to keep the mainsail from flapping. In the afternoon, however, we had an unlooked for diversion, for what had been hitherto considered as the indication of a fire lit by some Einos on the coast proved to be the smoke of a steamer which, rounding the point at that moment, bore down upon us. She was at once recognised by Baker as the Kuroda, a screw-boat belonging to the Japanese Government, in which he had served as mate before joining us at Hakodati, and in which he had assisted to convey the settlers from the island of Saghalien. Being anxious to hear if there was anything stirring up North, we at once lowered a boat into which Baker descended, and as the Kuroda, in common with most of the Japanese steamers at that time, was officered and engineered by Englishmen, they quickly recognised their old shipmate, and as soon as they were abreast of us the engines were stopped and we remained for a quarter-of-an-hour almost within hailing distance. 
The news which Baker brought on his return was by no means reassuring. The unmistakable reluctance on the part of the Hakodate custom house officials to give us our clearance papers, and the remissness of the Governor of Nemoro in failing to deliver the iron knees, which but for our builder's ingenuity would have been absolutely necessary for the construction of the Snowdrop, have already been touched upon; these matters, taken in conjunction with the late colonising movement and the high-handed conduct of Russia, had been a subject of frequent discussion among us; and as we were aware, before leaving Yokohama, that considerable diplomatic correspondence, coupled with strong protests on the part of the Japanese, had been going on with Russia respecting the Kurile Islands, it was extremely probable that the former, who are a spirited and warlike race, might, without actually declaring war with their more powerful neighbour, take such steps as to avoid any further annexations by bringing these islands under their more immediate protection; in fact, it was no secret at the time that Russia had endeavoured first to filch them and then to purchase them from their lawful owners. So that when Baker informed us that it was the intention of the Japanese to send up an expedition to the larger islands of Kunashir and Yetorup, to the latter of which we were bound, we were not taken by surprise; but when he added that they had determined to put a stop to all otter-hunting, we felt that things were getting serious for us.

True, we were aware that, according to international law, their jurisdiction could not extend beyond a radius of three miles from the coast, and that the sea otter is as often as not found considerably outside that limit. But this was poor consolation at the best, for with light winds, constant fogs, and powerful currents, we might be weeks without knowing our whereabouts, unless within easy reach of the shore; in which case, 
to lose touch of the schooner would be almost certain destruction to those in the boats. For this to happen, even when near the coast, was often bad enough, as the surf was generally too heavy to admit of landing, but when inshore we could always fasten the boats to the beds of kelp, and this growing in twenty or thirty fathoms spread the long leaves so effectually over the surface as to prevent any sea from breaking. In this manner, when unable to find the vessel, we afterwards spent several secure but miserable nights. These difficulties were bad enough but had to be risked. Wood and water, however, would be required at least once a month, and with a blockade, or even prohibition, approach to the shore, in the event of discovery, might lead to capture and confiscation. The fact also that the Governor of Nemoro, who, as as already mentioned, had withheld our stores, was strongly suspected of being the prime mover of placing obstacles in our way, since capture of otters might interfere with his perquisites, was calculated to cause us much uneasiness; we had already had annoyance enough and did not want any more.

For these particulars, which were sufficient to give us plenty of food for thought, we were mostly indebted to one of the crew of a small schooner which had been wrecked early in the winter in Hitokatpu or Jap Bay, and who was now being conveyed to Hakodate with a number of the skins they had obtained, leaving the rest of his companions on Yetorup to patch the vessel sufficiently to permit of their return.

It appeared from the account given by this man that their vessel had started very late in the season, intending to remain all the winter amongst the islands to hunt the sea otter. Though not yet very successful, all went well until one night in the beginning of December they had run into Hitokatpu, a large open bay, the only place bearing any resemblance to a harbour on the whole of the eastern coast. As the wind had fallen and the sea was quite calm, 
they felt perfectly secure, and had turned in after a hard day's work when, without the least warning, a succession of huge seas-either the effect or precursors of some distant storm-set right into the bay; and when the half-clad crew had tumbled up to face the bitter cold of a December night the cable had already parted. The wind soon followed the seas in keen and cutting squalls; a rush was made to loosen the sails, but they were frozen stiff as boards, each reef point and gasket like a bar of iron, and before another anchor could be got out they were in seven fathoms of water. The seas had begun to break and they were clinging to the rigging; the night was dark and to its horror was added a blinding snowstorm; clouds of foam poured over the deck, drenching them and presently to freeze on their half-naked bodies. Few minutes elapsed, though each seemed an hour, ere, borne along by resistless strength amidst a rush of seething froth and spray, they were hurled half frozen and helpless upon the desolate shore. Fortunately they had been heaved upon a bight of the bay where there was nothing but sand, so that as the litttle craft had been pitched well up, she did not go to pieces.

When daylight appeared they all got safely to land. But in what a plight! Most of their provisions were spoiled; the whole of the eastern shore of the island they knew to be totally uninhabited; nor was there the remotest chance of being rescued before the following spring. Remembering, however, that there was a good house a few miles off, which was used as a fishing station during the summer months by the small colony of Japanese on the opposite coast, and, as nothing could be done until the sea went down, they set out in a heavy snowstorm; and having reached their destination, they broke open the door, a good fire was started, and a meal off the dried salmon which hung in abundance on the greasy rafters made them forget, for a time at least, their awkward position.

After about a week of this life, during which, the sea having moderated, they stripped the vessel of as much as 
they could, they were joined by some of the natives, and with their assistance the craft was hauled up out of danger. Nothing now remained to be done except to pass the weary months as comfortably as possible; they accompanied the islanders to the western and warmer shore. There they spent a miserable six months, being often half-starved; for the addition of several mouths to feed put a severe strain upon the resources of so small and poor a community, who were able to lay up but little store for winter use beyond that which they absolutely required for themselves.

The forlorn party, however, managed to shoot several bears, and these, with the flesh of seventy-five otters they were able to procure, constituted the main supply of food till the welcome arrival of the Kuroda.

Jack, as a rule, has little to say of his sufferings; the simple phrase, "we were wrecked," or, "we lost the ship," is usually the sum of his remarks. It is only when described with the graphic pen of a Clarke Russell that scenes of suffering and hardship attending a wreck are brought prominently before the eye with full effect. Scarcely a day passes but the same story, told in the briefest outline by the newspaper reporter, is met with, and read over without any but a passing emotion. Perhaps it is only those that have experienced the horrors of shipwreck who are able to realise in an adequate degree the details of misery and privation which go to make up the story.

The little Snowdrop was fated to furnish just such an episode under almost identical circumstances of season, locality, and disaster, with the sole difference that, less fortunate than her predecessor, she was to leave her tough timbers rotting on the shore the very next year. But as Gray says : "Where ignorance is bliss, 'tis folly to be wise." And youth is, or ought to be, full of the buoyancy of hope, and its anticipations bright and rosy tinted. Moreover, we had no Cassandra on board in the shape of a grizzled boatswain to shake his head ominiously and croak over the recollection of having set sail on a Friday, or that the cat 
had jumped into the sea. The only depressing influence was the obstinate lightness of the wind, which caused our progress to be miserably slow. Talking about Friday, we were one day discussing the superstitions connected with it among sailors, when Mr. Thompson, our builder, told us that his father had once laid the keel of a large vessel and launched and sailed on this unpropitious day, and yet she was the luckiest vessel he ever built. Snow, however, followed on the other side, and proved by his log that, curiously enough, not only the sailing, but every mishap from the dismasting to the burning of the unlucky schooner in which he served, had happened on a Friday. So deeply engrained is this superstition in sailors that Jack seems positively unhappy if nothing occurs to justify it. Sensible commanders accordingly, however much they ridicule the prejudice or feel tempted to defy silly prognostications, avoid, if possible, leaving port on this day in deference to the men, for the simple reason that for a sailor to anticipate disaster is almost equivalent to courting it. 


\section{CHAPTER IV.}

Anxious as we were to get on, the wind remained provokingly light; never freshening, but just sufficient to allow of our making a trifling headway against the current. This continued until next morning, when it fell a dead calm which lasted until the afternoon. All at once a stiff northerly breeze sprung up, of which we took full advantage, beating up as carefully as if we were sailing a race. Steadily, but surely, we made up for lost time, and by nine o'clock were nearly abreast of Cape Noshap; another hour would have seen us round this point and out of the current, but it was not to be, for, as usual, the wind died away, and as it was too deep to anchor, in that hour which should have given us a snug berth for the night, so strong was the current, we had drifted back, over the space that had taken us six hours to beat up, to the place whence we had started when the wind met us, and there was no alternative but to anchor till morning.

Cape Noshap, which stood out temptingly before us in the bright moonlight, is the extreme east point of the Island of Yesso, and terminates a long and comparatively low-lying peninsula, about the middle of which, but on the western shore, is the harbour of Nemoro, a mere indentation on the coast protected by a small rocky island. The Cape itself was stated in the chart to be furnished with a "flash-light" seventy-four feet high, visible at a distance of six miles. We were, accordingly, much surprised that although within that radius, a good glass was required to see it at all, and certainly there was no flash about it; in fact, to judge by its hazy appearance on a calm and cold night, it was nothing 
more than a Japanese lantern, or a "Chochin," such as may be seen at home suspended from trees at an illumination or fête, a collapsible paper affair with a snuffy candle inside. Perhaps the flickering of the latter produced the flash, which really only existed in the imagination of the hydrographer. The latest chart, with corrections and additions to 1883 , extends the illuminating power of this miserable speck to ten miles, but it is very doubtful whether any improved apparatus has been substituted. Near this spot a small sloop called the Kanki, while on her voyage to the otter ground, lost her skipper and had to return. It was reported that he had been knocked overboard by the boom during a squall; this was the account given by the crew, a couple of Japanese, though there was reason to doubt whether this was the fact. Without boats or even a small dinghy it was the greatest folly to have made the attempt, and it is possible that the native seamen may have got rid of their quixotic captain so as to have an excuse for giving up the adventure.

Extending from Cape Noshap in a nor'east by east course, and parallel with the Kurile Chain, lie a number of low flat islands and rocks, terminating in the larger island of Shikotan, about forty miles distant. Judging by the formation, there is little doubt that at one time these islets were connected with the coast, forming a long narrow peninsula enclosing an inland sea from thirty to forty miles across. The largest of these islands are Shibobzu, Suisho, Taraku, and Yuru, varying in area from seventeen to two and a half square miles. They are all uninhabited, being only visited in the summer for the sake of the seaweed to be gathered there, and, dried on the beach, is put up in bales, and shipped by junk to China. Four miles to the scuth-east of Taraku are three or four clusters of rocks called Todo-shima, a favourite resort of the sea lion (Eumetopias stellari). Two of these, low, flat, and treeless, each with its girdle of pure white sand, shining in the distance like snow, looked like gems in a silver setting as they lay bathed in the bright moonlight on our starboard bow. 
These islands during the summer are the haunt of large numbers of the plover kind and other waders, which no doubt frequent them for the purpose of breeding; but it was probably early yet, as none of their weird cries disturbed the perfect stillness of the night, nor during the next day did we either see or hear any signs of them. Very few seals had been observed since passing Cape Yerimo, but there were evidently some here, for during the night Snow and I, who had come quickly upon deck to observe the weather, were startled by a number of splashes in the water close alongside, caused doubtless by some of these animals, either attracted by curiosity, or, more probably, passing with the strong Arctic current through the channel to a more southerly and warmer latitude. But the moon had gone down, and it was too dark to see anything-even the "flash-light." Morning dawned with a gentle breeze, a bright sun soon dispelled the early mists which hung over the waters. Making short tacks, running as close in shore as we dared, and taking advantage of every little promontory which checked the powerful current, we continued gradually to make up the way lost on the preceding evening; fortunately, the sea was quite calm, the wind being so light as scarcely to ruffle its surface, and so long as it kept clear we made some progress, but presently a dense fog rolled down from the north, causing the wind to become lighter, and introducing an element of danger that seriously interfered with our sailing and tacking. Our misgiving was soon justified, for about eleven, when we were all on deck, Snow happened to say, "I wonder whether there are any barnacles on the ship's bottom?" A remark elicited by our slow progress. In consequence of his remark all eyes were directed over the gunwale, and to our horror we discovered ourselves over a mass of sunken rocks. There was just enough wind to put the ship about, and at that moment the fog suddenly lifted and we became aware of our position, which was within two hundred vards of the shore. Not ten feet from us were pointed 
rocks above the surface; had we drawn a little more water we should inevitably have stuck on a reef. True, the sea was calm and there was no wind, but on this coast five minutes is a sufficient time to bring a gale howling about one's ears, and a sea heavy enough to break up a frigate will sometimes set in where but an hour before all was calm and smiling. Consequently, we were very thankful for escaping from what might have been at least a dangerous position, entailing further delay. The fog showed no signs of coming on again, so we proceeded with renewed confidence, but so slowly that evening was fast drawing in before we rounded Cape Noshap, and we were compelled to anchor for an hour through the wind falling. After tea a light breeze sprang up, and, turning our bow to the southwest, we ran down the other or the western side of the peninsula till Nemoro light was sighted; there we anchored for the night about a hundred yards from the island which shelters the settlement and on which the light is placed; the anchor watch was set, and we were not sorry to get below.

There was a good deal of what a Chinaman would call "talkee talkee" in the cahin that night. All were well aware that we had reached the most momentous period in our cruise. Our own suspicions, amply confirmed by the information obtained on board the Kuroda, left little doubt that the recovery of our stores left in the hands of the Governor would be attended with some difficulty, though how he could refuse to restore property to which he could not lay the slightest claim and for which we possessed his own sealed and signed receipt was a question we could not solve; but the ways of a Japanese Governor are frequently inscrutable. A charge for storage it was certainly his right to impose, if he thought fit, and that, of course, we were quite willing to pay; anyway, the fact could not be overlooked that it was within his power to be very obstructive and disagreeable, for his authority here was almost absolute. The Government, to whom alone he was accountable, was some hundreds of miles distant, and we knew well that any 
appeal from him must be sent through tortuous channels and entail a delay of months before an answer could be obtained, leaving us in the meantime to kick our heels at Nemoro. The next day would be May 2 ist, ten days having been consumed in sailing from Hakodati harbour over a course of two hundred and eighty miles. And now, from where we lay, but seventy or eighty miles-only half a day's sail with a good breeze-separated us from our hunting grounds. But it was, after all, of no use to anticipate contingencies and difficulties which might never arise; so, until the Governor should declare his hand on the morrow, we were fain to turn in and get a good night's rest, for the schooner was as steady as a farmhouse, resolving only that he should find that he had not Japanese to deal with this time, and that it would go hard if we did not adopt some means-force if necessary-to thwart him in any little scheme of personal profit at our expense. As to his prohibiting otter hunting, there were other places to which we could go-the Aleutians, or even Kamschatka if so minded.

At daybreak we got up the anchor, and taking a short tack, ran in and brought up in front of the settlement. in three and a half fathoms, and about fifty yards from the shore. Large quantities of gulls dotted the sand and gravel bank which formed the low ground of the peninsula, while upon rocks of no great elevation, about a couple of hundred yards off, were two white-tailed eagles, preening their feathers in the morning sun. It was interesting to observe how the presence of these lordly birds affected the gulls, for no sooner were they conscious of the nearness of their dreaded foe, than, with a yell seemingly more of anger than fear, the gulls rose in a mass, screaming continuously, although the eagles never took any notice of them.

After breakfast, Snow went to call upon the Governor, and took with him, as a present, some central-fire cartridges for a gun which he had presented to him the preceding autumn. The skipper and I lowered another boat, and pulled for the island, with the intention of shooting some 
of the dovekies or black guillemots (Uria troila) that were swimming about among the rocks or flying over the island to a small bluff at the farther end of the harbour. I was soon successful in bringing down some of these interesting little birds, which I now met for the first time. Their plumage is a sooty black all over, with the exception of a white ring round the eyes; their legs are of a bright scarlet, and the inside of the mouth and gullet are of the same colour; the bill is like that of a water-hen. In size they are smaller, and in motion more active than their aldermanic congener, the common or foolish guillemot. When flying, their outstretched legs looked like a scarlet tail, similar to that of a grey parrot. To tell the truth, our eagerness to procure specimens arose from the belief that we had met with a new variety. Rover, my black curly-haired retriever, who had been my companion in many a good day's snipe and pheasant shooting, was perhaps as keenly interested as anyone, and took much delight in retrieving the little black birds, doubtless thinking it more like old times and much more agreeable than dull life aboard ship. The birds showed little of the proverbial stupidity of their genus, for, soon becoming wary, they kept out of range, and shots occurring at longer intervals, after a time ceased entirely.

My attention was, however, soon centred in the little pools left by the receding tide, each one a miniature aquarium with a wealth of many-coloured shells and seaweeds, among which anemones of varied hues bloomed like many-petalled flowers in these gardens of Neptune; while bright coloured starfish in changing shades from crimson to scarlet, square in shape with slightly elongated corners, clung limpet-like and motionless to the smooth grey rock, each form of life, however humble, seeking to outvie the other in producing a picture of beauty and colouring framed by the grey rock of the island. While examining one of these miniature seas so full of life and colour, a low growl from the dog caused us to look up, and about thirty yards 
off, for we were close to the sea, we caught our first glimpse of a sea lion, and a magnificent fellow he looked. Perfectly motionless in the smooth sea, he reminded one of a huge frog with his great broad shoulders just visible above the water; he seemed to regard us with a mild curiosity. Before we could recover from our surprise he turned his great head solemnly from side to side, as if unable to come to any satisfactory conclusion about us, and sank in that slow, eerie way common to the seal tribe, so suggestive of a drowning man. On our return to the schooner, we found Snow in no very pleasant frame of mind. The Governor's reception had not been so gracious as at the former interview, and, in spite of his promises and in the face of his own papers and signature, he now positively refused to give up our property; the only concession he made was to allow us to remove our anchors and chains, and that only after Snow had assured him in the most forcible manner that, in the event of disaster, a more than probable contingency if we left without them, he alone would be held responsible. This rather alarmed him, for at that time England was represented in Japan by a minister whom of old the Japanese knew they dared not trifle with; this gentleman was the late Sir Harry Parkes, to whose uprightness of character and zeal for the service British influence in the country was entirely due. While on this subject I may say that it is a pleasure to know that his eminent qualities were fully appreciated both at home and abroad, and his death shortly afterwards in China, to which country he was transferred, was universally regretted; but only those whose immediate interests he so ably cherished and protected are in a position adequately to judge of the success of his ministrations.

As nothing more could be done that day we rowed ashore to have a look at the village. We found it consisted chiefly of fish-curing establishments, which formed a street stretching along the beach. The better class of houses, perched on the side of the hill rising behind them to the 


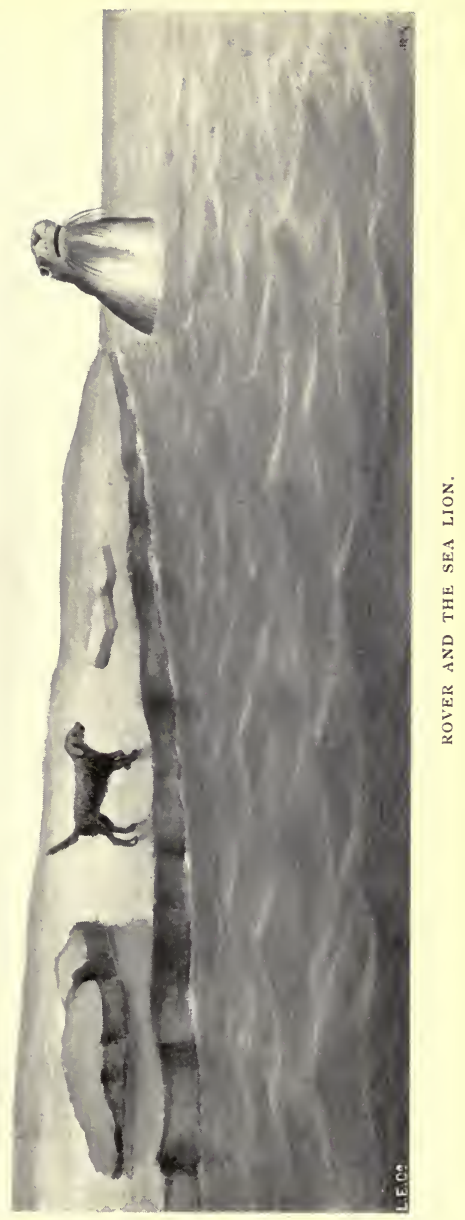


height of about three hundred feet, were protected from the cold east winds and almost hidden by the dense growth of stunted oak and beech, already beginning to put forth leaves. Vegetation, though late here, is very rapid when once the snow has gone, and now only the mountain range, running to the north-east, retained its wintry aspect. Here and there single trees and small clumps of the Pinus Fessoniensis, the only tree that seems capable of rearing its head above the storm-twisted undergrowth, relieved the monotony of the wooded slopes. The principal occupation of the people was the curing of the hard roe of the herring and boiling down the rest of the fish for manure. In May and June this fish swarms on the coasts in enormous shoals, the bays and creeks are almost choked with them. Immense quantities are literally pushed up on the shore by the sheer weight of those behind; on every bit of shelving beach they form a silvery belt of food for eagles, gulls, foxes, and bears, which become fat and sleek on this plentiful supply. A net supported on stakes driven into the bottom about a hundred yards from the shore, is spread by the natives, the fish killed by the pressure of the superincumbent mass sink to the bottom, the rest crowding outwards in incredible numbers into a cul-de-sac at the end; so great is the weight that it would be impossible to lift the bag, they have, therefore, to be scooped out with long-handled landing nets and emptied into unwieldy barge-like boats alongside. That morning we counted seven boats, capable of holding about twenty tons each, loaded to the gunwale carrying their gleaming green and silver cargo to the shore from one net alone. Removed from the boats in large creels, they are deposited in huge pens and piled up in stacks. Near these pens are cauldrons in which they are boiled, the oil being ladled out or allowed to run off into sunken tubs, or small natural reservoirs. The boiled mass is then transferred to wooden lever presses, roughly about two feet square but somewhat smaller at the bottom than the top, and weighted with stones the more effectually 
to express the oil. The remaining work is to stack the cubes obtained from the presses, and when sufficiently dry they are broken up and spread on mats in the sun and finally packed in straw bags for exportation. Whether these are the same species as those that frequent our coasts it was impossible to say. Their flavour was far inferior, and no amount of boiling or frying could make them palatable, much to our disappointment, as we had counted on a treat. Their insipidity might be owing to the low temperature of the water, which is quite twenty degrees below that on the coast of Scotland, but of course they were out of season and spawning. After having had a look at the little settlement, Snow and I strolled along the rocks and shot twenty-seven small grey plovers and a couple of dovekies. A grand council of war was held that night, in which it was decided that next day we should go in a body to the Governor and insist upon our property being given up; at the same time three of the boats should be lowered and all the crew taken on shore, so that, once the dor of the godown open, we should be in sufficient force to take away what we required. Failing this, we would take our rifles with us, break open the door, and defy them, for we were determined not to be robbed in such a cool manner because the Governor happened to be a rogue. Next morning, after breakfast, we pulled ashore in the three boats, leaving only the cook and Rover aboard. We went first to the interpreter's house and were told he would see us in a few minutes, but we soon discovered he had left by the back way to avoid us. When we reached the Governor's house he came out and informed us that the godown was already open, and the anchors and chains were being got out. Doubtful whether this were but a subterfuge, or whether a march had not been stolen upon us, we were not long before we reached the godown, and found, much to our delight, not only the door open, but nobody there, the interpreter having evidently gone to hurry up the coolies to do the work. This was a rare piece of good luck, of which we 
were not slow to take advantage. Leaving the others to get out as much as possible, I ran off to the boats, and brought them to the nearest point; ten extra pairs of hands made short work, and anchors and chains, barrels of salt junk, boring powder, Winchester cartridges, and a spare suit of sails were quickly bundled out and carried down to the boats. Just as we were finishing, down came the Governor, purple with wrath, accompanied by the interpreter and another yakonin, to whom he seemed to be using what Mark Twain calls "familiar quotations," and half-a-dozen coolies. The two yakonins, after chattering away with the Governor in a high key for a minute, sprang into the godown, fairly turned us out, and locked the door. We took it all in good part and fairly laughed at their impotent rage, for we had obtained all we required, otherwise the turning out would have been on the other side, for Englishmen have a strong objection to be handled by a native. Such a proceeding might have entailed serious consequences, as we were quite unarmed, while they each carried the usual complement of two swords, a long one for offence and a short one, or long dagger, for use upon themselves in the event of having recourse to the Harukiri, or happy dispatch, which consists of disembowelling themselves, while a friend stands behind to complete the act by decapitation. With unsuccessful governors of fortresses, unable to hold out, and with beaten generals, this has always been a common and convenient resource, avoiding both courts-martial and executioners' fees, besides possessing the advantage of removing all stain and disgrace from the surviving family of the self-" dispatched." The other sword, a double-handed, heavy weapon, is used very dexterously, considering its weight, and we had more than once seen a man's head taken off at a single blow, without apparent effort. The first, or drawing, cut as the sword leaves the scabbard is very clever and sudden, so much so that it was always the rule in case of dispute to shoot down a man who laid his hand on his sword, for that meant 
drawing, and to sheath without blooding was always considered a disgrace.

However, "All's well that ends well," and we were not further interfered with. The irate trio took themselves off in high dudgeon, leaving the coolies, who, no longer awed by the presence of their superiors, allowed their faces to relax into a comfortable grin, showing they rather enjoyed than otherwise the official discomfiture. Meanwhile, the boats plied backwards and forwards, and before evening we had everything aboard, with only one hitch. This occurred in getting off the heavy anchor. The dingy in which it was stowed just managed to get alongside of the schooner, almost gunwale under, when a few larger waves than the rest completed what the slight ripple had endeavoured to accomplish all the way out, and down it went, depositing the crew in the water and the anchor at the bottom in three-and-a-half fathoms. The lead was at once dropped over the place. As we were slewing about somewhat, the wind coming in eddies round the rocks, the men in the water were soon picked up. Divers were at once called for, and a couple of dollars being offered as a stimulus, a volunteer stepped forward, but he had no sooner reached the water than he clambered back, with the remark that it was "taisoo samui" (very cold). Things looked bad, none of us could dive, and though we all knew that Japanese sailors are, as a rule, good swimmers and divers, we did not appear to have one on board. Presently old "Junky," as we called him (from being an old junk sailor), a dried-up specimen of humanity, but looked up to with considerable veneration by the rest of the crew, probably on account of the dangers he had not gone through-for he was remarkably careful of himself-doffed his long gown, pulled off his blue tights, and, taking the manilla line to reeve through the anchor ring, disappeared down the lead-line. In half a minute he was on deck with the rope, and in half an hour the anchor was safely hauled up. This opportune service of old Junky's was not overlooked. 
A present of four dollars was at once given to him, and, whenever the chance occurred, as it frequently did, to shoot a few shags or cormorants for him, we never lost the opportunity, for their flesh was as great a delicacy to him as turtle to an alderman. All setting to work with a will, the boats were soon unloaded, hoisted on deck, and lashed in their places. The cargo was safely stowed in hold and magazine; and the wind favoured our eagerness to leave the inhospitable port, for a good stiff south-westerly breeze set in, and so, with a wet sheet and a feather at the bows, we were soon cleaving the water on our trim north-east course at the rate of eight knots. The wind kept fresh and steady all night, although, as usual, the morning broke cold and foggy; as day advanced, the haze, concealing the outlines of the islands of Kunashir, which lay on our port bow, lifted like a curtain and revealed a mountainous island, from which rose here and there, like giants of their race, volcanic cones, piercing the heavens with their lofty shafts, and, dominating them all, St. Anthony's Peak towered to the height of seven thousand four hundred feet. As we gazed, the sun, as if at length ashamed of his tardiness, for the morning was now pretty far advanced, emerged from cloud and fog and shed a rosy radiance on the scene. The shore of alternate black rock and shiny sand, the stunted forest growth that formed its background, the snow-clad mountains, here smooth, there jagged in outlines, were all irradiated by the warm, soft light-truly an enchanting place for the sportsman or naturalist, smiling just then in all the pride of its new-gotten greenery, smiling but desolate, solitary and unexplored, a land of the eagle, the bear, and the fox. There the wild swan, whose plumage vies in whiteness with the eternal snow on the lofty peaks, rears her downy brood in solitude, mid swamps forest-girdled, unseen save by the hungry fox or the swooping eagle: but she quits the shaded scene, obedient to instinct, ere winter, more fatal than bird or beast of prey, binds in its iron grasp both land and wave. 
The island of Skotan lay on our starboard quarter, rising with its mountains to a height of one thousand four hundred feet above the sea; the bright sun and swiftly passing clouds showed their summits of the colour of heather in every change of light and shadow. Skotan is entirely uninhabited, a few Einos in the summer months only use the one little land-locked harbour for their nets and boats to catch and cure fish for their winter provision. It was intended to explore the island on our return, and if it seemed prudent to winter there for the purpose of trapping, as a black fox had been shot here by an American whaling captain, but circumstances were not favourable, and probably the dangers to be encountered would not have been compensated by the profits. By nine o'clock the fog, which still enveloped Yetorup, lifted bodily, and we caught a first glimpse of our destination in the bold rocky headland of Roko Bay. 


\section{CHAPTER V.}

BEFORE resuming our narrative, it will be as well to give the reader some information concerning that curious and almost unknown animal the sea otter. In doing so, I have thought it advisable to amplify our own observations by those to be obtained from the few authentic sources available, and so to place all possible knowledge concerning the animal at the service of the reader, and more especially to give him details as to the hunting, since the method employed by the tribes along whose coasts it is found differed very much from that adopted by our party.

From the tiny weasel with its lithe body and active movements the family of Mustelid $x$, through well-defined genera of maiteus, skunks, badgers, etc., culminates at length in the sub-family Enhydrinx. This group is represented by a single genus and species, the sea otter (Enhydris lutris); it is, moreover, the only thoroughly marine member of the whole family, and its only habitat lies around the islands and coasts of the North Pacific Ocean.

The length of the full-grown male is as nearly as possible four feet from nose to root of tail. Our largest skin when nailed upon the drying frame measured sixty-three inches over all, of which the tail was about nine inches. This skin was not stretched more than was absolutely necessary, as to do so destroys the appearance and value of the pelt, but so loose or rolling is it that nearly, if not quite, twelve inches must always be allowed for in estimating the length of the carcase which it has covered. The girth of the long, cylindrical body varies from two feet six inches to three feet. 
The illustrations of the sea otter usually met with, even in scientific treatises, are quaintly incongruous. In some it is represented as something between a black bear and a wolverine; in others as a gay and festive weasel. Both are equally erroneous and misleading, while they utterly fail to give any true idea of its habits or appearance. The fore paws are rudimentary, being very short and weak, and quite useless either as a means of progression or for raising the body from the ground, while the hind flippers, as in the seal, are only of use when in the water. Nor are they brought together as in the phocidx, but are placed almost exactly as are the hind legs of the common mole.

In fact, if the reader will imagine a gigantic mole with the head of a river otter and the fore paws of a cat, the latter each about four inches long, only widely placed and just meeting when folded over the chest, he will get an excellent idea of the appearance of the sea otter.

The comic showman defines an amphibious animal as one that lives on the land and dies in the water. In the present case, the exact reverse of this would seem to hold good, considering that, among the many hundreds of sea otters met with in our expedition, only in one solitary instance was one shot above watermark, and this, on being skinned, was found to have been so terribly injured as to have sought the shore to die. Viewed in a commercial light, the pelt is one of the most valuable of all the fur-bearing animals; for this reason the chase and capture of the creature who wears it has long been an important industry. In spite of its having been known for an indeterminate time to the Katines, on whose shores it was found, to the Kamschatdales, as the "Kalan," and to the Russians as the sea or Kamschatka beaver, the skin having been an important article of trade in China, whose high-class mandarins loved to trim their robes with its beautiful fur, it was not until the middle of the last century that a description having any scientific value was given to the world, when the celebrated navigator, Steller, in $175 \mathrm{r}$, under the name of Lutra Marina, 
gave a sufficiently accurate account of it to be quoted and consulted to the present day.

Dr. Elliott Coues, in his admirable monograph on the American Mustelidæ, gives no less than fourteen Latin designations to the sea otter, as applied by as many different naturalists, some classing it with the seals, others with beavers and river otters. That these mistakes should have arisen is scarcely a matter for surprise, as few, save the native or American hunter, ever had the opportunity of seeing them alive, much less of studying their habits and scientific distinctions. The similarity of the sea otter to the seal is entirely confined to the fact that both possess flipper-like hind feet. There all physical likeness ceases, though they certainly approximate more to the seals than to the otters in being purely marine in their life and habits. Instead of the sudden tapering of the tail, as in the seal, the sea otter has an almost cylindrical body, abrupt behind, tapering forwards to a long, flat-topped head; in repose the neck appears short, but when alarmed it is capable of being stretched above the water to such an extent as to give the animal a rather graceful appearance; when lying dead upon the deck the general outline is very much like that of a gigantic mole; the limbs are short, the tail, never above a foot in length, is somewhat flattened and of even breadth to within an inch and a half from the end, when it abruptly tapers. There is a marked disparity between the fore and the hind limbs both in size and shape, the former being very short, terminating in paws like those of a cat, while the latter are broader and shorter than those of the seal, having elongated digits webbed by membranes stretchfrom tip to tip of all toes and furnished with short, stout, arched claws. Both digits and membranes are covered on either side with stiff, coarse hair. The eyes, of moderate size, are placed high up in the head, the ears low down, sharppointed, short, and hidden in the fur. The skin is remarkably loose and "rolling," and when removed is seldom less than twelve inches longer than the animal itself. The 
colour of the fur is a dark liver brown, with very thinly scattered fine hairs somewhat longer than the rest. In the finest skins the pelt is very dark, and the hairs interspersed more numerous, but black with white tips, and the whole appearance is very beautiful. As the animal grows older the head assumes a yellow colour, some of the old bulls having the head almost white. Judging from the character of the teeth, the food of the sea otter is almost exclusively shell-fish; the grinders have a singularly massive, almost bulbous form, without trenchant or even angular edges. An examination of the contents of many of their stomachs showed no sign of anything but mollusc diet. That the female seeks the shelter of the kelp beds when about to bring forth her young is very probable, more especially in rough weather, but that this shelter is not necessary we proved in several instances by shooting them with newlyborn pups, many miles from either shore or kelp beds, the placenta not having yet been voided. The cry of the adult, only heard by us at night, is exactly like the mew of the domestic cat. Sometimes "schools" of from one to two hundred were met with, but, as a rule, except in the kelp beds, where a few might be seen together, we found them singly or in pairs.

The following account of the sea otter, and the method of hunting it is taken from Mr. H. W. Elliott's report on the condition of affairs in the territory of Alaska in 1835 .

"The sea otter, like the fur seal, is another illustration of an animal long known and highly prized in the commercial world, yet respecting the life and habits of which nothing definite has been ascertained or published. The reason for this is obvious, for, save the natives who hunt them, no one properly qualified to write has ever had an opporcunity of observing the enhydra, so as to study it in a state of nature, inasmuch as, of all the shy, sensitive beasts upon the capture of which man sets any value whatever, this creature is most keenly on the alert and difficult to obtain; and also, like the fur seal, it possesses 
to us the enhancing value and charm of being principally confined in its geographical distribution to our own shores of the North-West. A truthful account of the strange, vigilant life of the sea otter and the hardships and perils of its human hunters would surpass, if we could give it all, the most attractive work of fiction.

"There is no sexual dissimilarity in colour or size, and both male and female, and both manifest the same intense shyness and aversion to man, coupled with the greatest solicitude for their young, which they bring into existence at all seasons of the year, for the natives get young pups every month. As they have never caught the mothers bringing forth their offspring on the rocks, they are disposed to believe the birth takes place on kelp beds in pleasant or not over-rough weather. The female has a single "pup," born about fifteen inches in length and provided during the first month or two with a coat of coarse, brownish, grizzled fur, head and neck grizzled, greyish, rufous, white, with the roots of the hair growing darker towards the skin. The feet, as in the adult, are very short, webbed, with nails like a dog, forepaws exceedingly feeble and small, all covered with a short. fine, dark, bister-brown hair or fur. From this poor condition of fur, they improve as they grow older. shading finer, darker, thicker, and softer, and by the time they are two years of age they are "prime," though the animal is not full grown until its fourth or fifth year. The white nose and moustache of the pup are not changed in the adult. The whiskers are white, short, and fine. The female has two teats resembling those of a cat, placed between the hind limbs on the abdomen, and no signs of more; the pup sucks a year at least, longer if its mother has no other; the mother lies upon her back in the water or upon the rocks, as the case may be, and when she is surprised she protects her young by clasping it in her fore paws and turning her back to the danger. 
"The sea otter mother sleeps in the water on her back with her young clasped between her fore paws. The pup cannot live without its mother, though frequent attempts have been made by the native to raise them, as they often capture them alive, but, like some other species of wild animals, it seems to be so deeply imbued with the fear of man that it invariably dies from self-imposed starvation.

"They are not polygamous, and more than an individual is seldom seen at a time when out at sea. The flesh is very unpalatable, highly charged with a rank smell and flavour.

"They are playful it would seem, for I am assured, by old hunters, that they have watched the sea otter for half-an-hour as it lay upon its back in the water, and tossed a piece of sea-weed up in the air from paw to paw, apparently taking great delight in catching it before it could fall into the water. It will also play with its young for hours.

"The quick hearing and acute smell possessed by the sea otter are not equalled by any other creatures in the Territory. They will take alarm and leave from the effects of a small fire, four or five miles to the windward of them; and the footstep of man must be washed by many tides before its trace ceases to alarm the animal and drive it from landing there, should it approach for that purpose.

"There are four principal methods of capturing the sea otter, namely, by surf-shooting, by spearing surrounds, by clubbing, and by nets.

"The surf-shooting is the common method, but has only been in vogue among the natives for a short time. The young men have nearly all been supplied with rifles, with which they patrol the shores of the island and inlets, and whenever a sea otter's head is seen in the surf, a thousand yards out even, they fire-the great distance and the noise of the surf preventing the sea 
otter from taking alarm until it is hit. And in nine cases out of ten when it is hit in the head, which is all that is exposed, the shot is fatal, and the hunter waits until the surf brings his quarry in, if it is too rough for him to venture out in his bidarka. This shooting is kept up now the whole year round.

"The spearing surround is the orthodox native system of capture, and reflects the highest credit upon them as bold, hardy watermen. A party of fifteen or twenty bidarkies with two men in each-as a rule, all under the control of a chief elected by common consent-start out in pleasant weather, or when it is not too rough, and spread themselves out in a long line, slowly paddling over the waters where sea otters are most usually found. When any one of them discovers an otter asleep, most likely in the water, he makes a quiet signal, and there is not a word spoken or a paddle splashed while they are on the hunt. He darts towards the animal, but generally the alarm is taken by the sensitive object, which instantly dives before the Aleut can get near enough to throw his spear. The hunter, however, keeps right on, and stops his canoe directly over the spot where the otter disappeared. The others, taking note of the position, all deploy and scatter in a circle of half a mile wide around the mark of departure thus made, and patiently wait for the reappearance of the otter, which must take place within fifteen or thirty minutes for breath; and, as soon as this happens, the nearest one to it darts forward in the same manner as his predecessor, when all hands shout and throw their spears to make the animal dive again as quickly as possible, thus giving it scarcely an instant to recover itself. A sentry is placed over its second diving wake as before, and the circle is drawn anew; and the surprise is often repeated, sometimes for two or three hours, until the sea otter, from interrupted respiration, becomes so filled with air or gases that he cannot sink, and becomes at once an easy victim.

"The clubbing is only done in the winter season, and 
then at infrequent intervals, which occur when tremendous gales of wind from the northward sweeping down over Saanach have about blown themselves out. The nativesthe very boldest of them-set out from Saanach and scud down on the tail of a gale to the far outlying rocks just sticking out above surf-wash, where they creep up from the leeward to the sea otters found there at such times with their heads stuck into the beds of kelp to avoid the wind. The noise of the gale is greater than that made by the stealthy movements of the hunters who, each armed with a short, heavy wooden club, dispatch the animals one after another without alarming the whole body; and in this way two Aleuts (brothers) were known to have slain seventyeight in less than an hour and a half.

"There is no driving these animals out upon land. They are fierce and courageous, and, when surprised by a man between themselves and water, they will make for the sea straight, without any regard for the hunter, their progress by a succession of short leaps being very rapid for a small distance. The greatest care is taken by the sea otter hunters on Saanach; they have lived in the dead of a severe winter six weeks at a time without kindling a fire, and with certain winds they never light one. They do not smoke, nor do they scatter or empty food refuse on the beaches.

"The hunting by use of nets calls up the strange dissimilarity existing now, as it has in all time past, between the practice of the Atka and Atton Aleuts and that of those of Ounalashka and the eastward tribes. The former capture the sea otter in nets from $16 \mathrm{ft}$. to $18 \mathrm{ft}$. long and $6 \mathrm{ft}$. to I oft. wide, with coarse meshes, made nowadays of twine, but formerly of sinew.

"On the kelp beds these nets are spread out, and the natives withdraw and watch. The otters come to sleep or rest on those places and get entangled in the meshes of the nets, seeming to make little or no efforts to escape, paralysed, as it were, by fear, and fall in this way easily into the hands of the trappers, who tell me that they have 
caught as many as six at one time in one of these small nets, and frequently get three. They also watch for surf-holes, or caves in the bluffs, and when one is found to which a sea otter is in the habit of resorting, they set this net by spreading it over the entrance, and usually capture the animal.

"No injury whatever is done to these frail nets by the sea otters, strong animals as they are; only stray sea lions destroy them. The Atka people have never been known to hunt sea otters without nets, while the people of Ounalashka and the east have never been known to use them. The salt water and kelp seem to act as a disinfectant to the net, so that the smell of it does not alarm or repel the shy animal." 


\section{CHAPTER VI.}

I SHALL now proceed to describe the boats, their equipment, rifles, etc., and give an account of the modus operandi in hunting the sea otter followed by ourselves and others employed on the same errand, whose vessels, schooners, and sloops we subsequently met with at various periods during our cruise. The boats were sharp at both ends like those used in whaling, and about fourteen feet long and five feet beam, carvel built, strongly made and low in the water, so as to admit of paddling when necessary; the bow was covered in for about three feet so as to provide a rest for the rifles, ammunition, etc., the under part forming a locker for provisions and spare ammunition. When not on the look-out, the hunter sat on the foremost thwart facing the bow, with his rifles, two heavy muzzle-loaders and a seventeen-shot Winchester, with cartridges, bullets, and powder before him. The next two thwarts were occupied by the rowers, each pulling a long oar; the steersman, sitting right aft, with a spare thwart before him, used to trim the boat when sailing, and underneath this was a small drawer carrying a boat compass, an absolute necessity where fogs were so sudden and so frequent. Each boat had a slight keel to admit of sailing, and when fully equipped carried three natives and one European; three rifles, two heavy muzzle-loaders, and a seventeen-shot Winchester for "breaching" otters, and four hundred rounds of ammunition, a pair of extra thole pins-more easily made and replaced than iron-a mast and sprit, spritsail and jib, oars, paddles, and a compass. The provisions consisted of rice and fish for the natives, salt junk, bread or biscuits, and cheese for the hunter. 


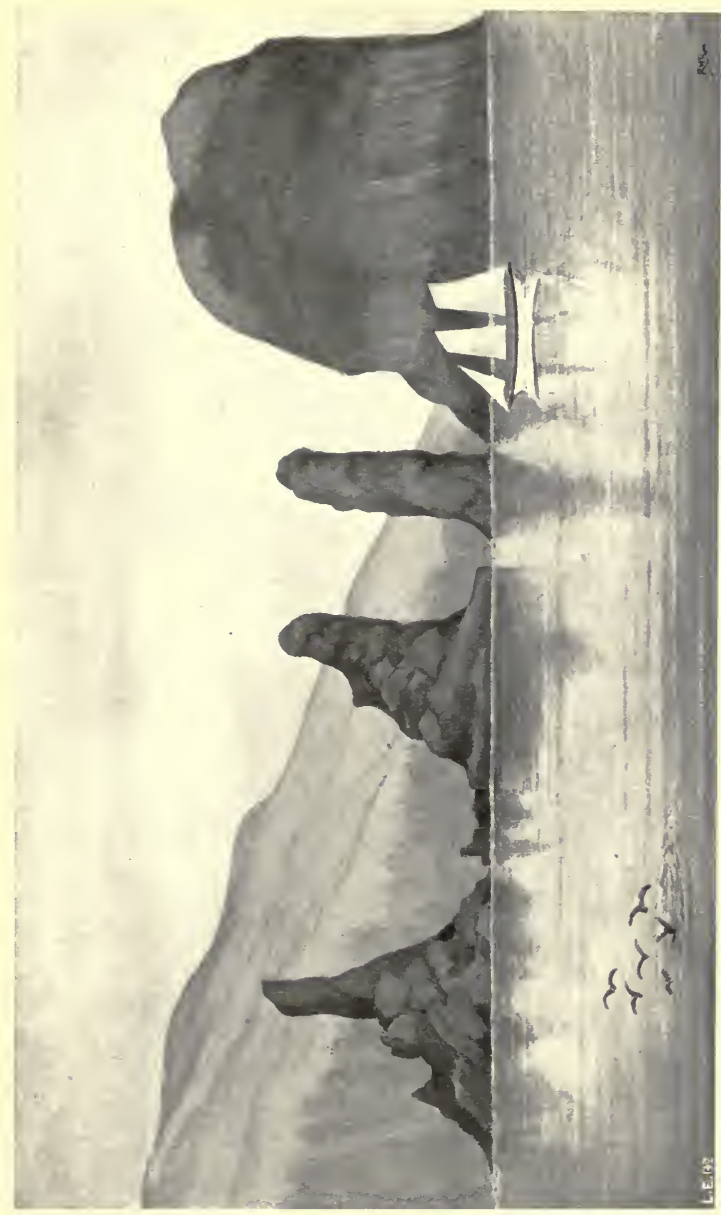

$\frac{y}{0}$
$\check{x}$
$\underline{x}$ 

The arms par excellence for this kind of work are: First, the old Kentucky muzzle-loading pea rifle with hair trigger, for single shots, or, at least, a modification of it, and the Winchester repeater for quick snap-shooting at "breaching" otters. This may seem to many a curious statement to make in these days of highly-finished breechloaders of a hundred types and fashions, and the old backwoods rifle of Fenimore Cooper's heroes is considered to have long been "relegated to the limbo of dead dogs." But the truth of my assertion is mainly proved by the adoption of this weapon for this particular sport among a class of men second to none as game shots, whose life and antecedents bring them in contact with most of the different rifles in use. They are natives of America, where the rifle is, or was then, used, and costs much less than it does in England. The reasons for its being a general favourite are not far to seek, for the accuracy of these long-barrelled, small-bore pieces, with their small charge of powder and spherical bullet, would surprise many who had not seen the shooting that can be made with them up to a hundred yards, and it is within that range that the otter hunter looks for a telling shot, though we repeatedly made and saw kills at double that distance. The sea otter, if struck in the head or neck is easily dispatched, the small bullet and corresponding charge of powder is amply sufficient for the purpose. When it is remembered that the marksman has to balance himself in a cockle shell of a boat in a sea rough or rippling, and to shoot at a moving object no bigger than a bulldog's head, it will be, perhaps, readily understood that the great weight and unequal balance of such an arm gives a steadiness of aim not to be obtained in one lighter and more easily directed.

These rifles could, of course, be easily converted into breechloaders, and certain reminiscences of chilled fingers that had to be carefully watched because they were too cold to feel the bullet, and teeth used to pull the greasy patches off the shoe lace on which they had been threaded, 
because the aching fingers refused to do their duty, are not easily forgotten; but as two are always carried in each boat, with the Winchester to fall back upon, no change is really required, except on the score of comfort, a consideration little studied by the otter hunter. Moreover, the time between the divings of the animal is generally sufficient for the purpose of loading. In a description of the fur-seal already given, there is an explanation of the term "breaching." It is on such occasions that rapid snapshooting is the order of the day and the Winchester is in request. Besides these two different kinds of rifles we had others by Rigby, Holland, Spencer, Ballard, and a Swiss match rifle, all of which, though good of their kind, were ill-adapted for our purpose.

The following will give an idea of the method of hunting : After a hasty breakfast, often by lamplight, the three boats were hoisted out and provisioned for the day, with sails, ammunition, rifles, and compass carefully seen to, we put off from the side as the first streaks of dawn began to light up the eastern sky: Proceeding in line with an interval of two or three hundred yards between each boat, according to the more or less foggy state of the atmosphere, each hunter standing upon the foremost thwart, a sharp look out was kept until an otter was seen, when the observer raising his paddle in the air to signify to the others that he had "found," rows straight for him as hard as his men can send the boat through the water. Should the otter be lying on its back, with eyes consequently but little raised above the surface of the water, the hunter may at times approach within a hundred yards, or even less, of his prey, and with a single, well-directed shot may, to use an Irishism, put an end to the chase before it had commenced. But so acute are the senses of these animals that as a rule, except when there is a heavy sea on, before the boat has arrived at twice that distance the otter is on the alert, and might be seen craning his head and neck above the water, observing with alarm and, unfortunately for him, considerable curiosity, 
the approach of so strange an object. But this does not last long, for he is naturally wary, and, turning his back upon the foe, swims rapidly away, until the ping or splash of a rifle bullet in more or less close proximity to his head, causes him to dive out of sight in a moment. As soon as the leading boat, which meanwhile has been pulling for all it is worth, reaches the spot where the otter dived, the men lay on their oars, the hunter and steersman keeping a lookout in all directions for his re-appearance. In the meantime, the other two boats have advanced, and taken up their positions in the rear, representing with the first as nearly as possible an equilateral triangle, and separated from each other by a distance of three or four hundred yards.

This pause in the pursuit is made in order to take advantage of the practice almost invariably followed by the sea otter of diving back behind the danger. This peculiarity is soon learned by the hunter, and ceases to baffle him. The very cunning of the move becomes the principal cause of its undoing, for should the otter, as was sometimes the case, elect to trust to his heels, or rather his flippers, the chances of escape, more especially in a seaway. were greatly in its favour, so small an object as its head being easily lost sight of in the tumult of the waters. Some of the American hunters, who had pursued them upon the Pacific Coast, declared that they had completely outgrown the habit of diving back, and, as soon as they caught sight of their pursuers, up tail and "breached" across the ocean as hard as they could go, so shy and wary do they become when much hunted.

Each hunter, rifle in hand, eagerly scans the space between the boats, ready to salute the reappearance of the otter with a bullet. This must be done as quickly as possible, so as to make him dive again before properly getting his breath, and so shorten the time of his stay under water. Should he make his appearance close to one of the boats, it is at once backed, the others closing in so as to 
keep him as much as possible within the area of the fatal triangle. Should the otter commence "breaching," or leaping like a porpoise every few yards, as they often did when hard pressed, the nearest boat takes up the chase, and, watching the line of bubbles pressed out of the pelt by the resistance of the water, holds his Winchester ready to take a snapshot each time of his re-appearance. Balanced upon a narrow thwart, with the boat propelled at its utmost speed, the steersman guided by the pointed rifle of the hunter, it becomes snap-shooting with a vengeance. The rapid shooting has, moreover, another object, that of so scaring him as to stop the "breaching" and cause him to dive back. When this is the case, the two boats, which in following have throughout maintained their proper position, cease rowing and prepare to pursue the same tactics as before. Frequently the otter breaks the water close to one after the other, and starts "breaching" at full speed from each in turn; and it is sometimes as much as four hours of such strenuous exertion on the part of both hunted and hunter before fatigue and shortness of breath give a favourable opportunity for a successful shot.

All too often for the hunter, good fortune favours the pursued, for he is either lost in a tide-rip or swallowed up in a fog. Not unseldom, some fierce volcanic blast will sweep down upon the frail boats without a moment's warning, and, catching up the crest of every little wavelet in its passage, churns the sea into foam and hides the boats in a cloud of spindrift, until, drenched and half blinded, the chase has to be abandoned for the sake of personal safety.

To proceed with our narrative. As we opened out the land more, the wind fell calm, leaving us tossing about in an ugly tide-rip, which, however, carried us rapidly along the the coast, so that by two o'clock in the day we were already abreast of Otter Island, a mass of igneous black rock situated about half a mile from the shore, marking the northern extremity of Roku Bay. The island got its name from the early hunters, who found great numbers of the 
animals frequenting the kelp bed which grows in the small bay on its inland side. Longing for the chase, from which we had been so long debarred by unlooked-for difficulties and adverse weather, we were all eagerly scanning the water when Snow sang out: "An otter, boys. There he is!" Another moment and we all saw a bullet-like head appear on the crest of a large wave. "Out boats" was now the cry, and in a very short space of time, considering the roughness of the sea and the unhandiness of the men, the boats were lowered and cast off; and, though the otter had by that time disappeared, we pulled gaily through the nasty cross sea for the island about four miles distant. As we approached the land we left the tide-rip behind, getting into smoother water. Snow, who was in advance, had no sooner turned the corner of the rock than we heard the report of his rifle, and were pressing on to join him when, without a moment's warning, one of those terrible gusts of wind which make this particular part of the coast so peculiarly dangerous tore with a scream of fury down the one solitary ravine that here breaks the continuity of the rugged coast, churning the sea into foam and drenching us in a few minutes with sheets of spray. Short as the distance was, it took us a hard pull, all hands rowing or paddling, to reach the friendly shelter of the island. Several otters passed close to us, but, unaccustomed as we were to keep our feet-much less shoot-in such weather, the few shots fired proved abortive. Nor was Snow more successful, though he had come quite suddenly upon no fewer than seventeen lying in the kelp, to the long fronds of which we soon made fast until the violence of the storm should subside, and when it did abate it was only to blow hard upon us from the opposite quarter, leaving the schooner too lightly manned on a lee shore. We saw at once that to save the vessel Baker would have to clear off as sharp as possible, but she had already as much sail on her as she could carry; while reefing with only the cook and boy to help, neither of whom could be trusted in such 
an emergency, was almost an impossibility, and, to make things worse, night was fast closing in. As to ourselves, the wind had grown bitterly cold, piercing our wet things like a knife; and, without provisions, a night in the boats was anything but pleasant to contemplate. So it was deemed advisable, though the sea looked very ugly, to attempt to reach the vessel, as the rough weather might not improve. This we accomplished in safety, after a long, hard pull, just as the daylight began to fail, and a glass of grog, dry clothes, and a little rifle cleaning soon made us comfortable. It was decided, however, both for the safety of the ship and comfort in the boats, to leave the steersmen aboard, the hunters taking their places and shooting from the stern. This was found to suit Baker very well, as there is always much to be done in a vessel, independent of the work of cleaning and scraping otter skins; moreover, while in the boats, the hunter always erect could readily fire over the rowers' heads, and, the boats being less down in the head, the men could pull better and were less exposed to getting wet.

Two hours after boarding, a dense fog settled down over us, and the wind died away almost as suddenly as it had arisen, leaving us at the mercy of the tide-rip, which literally roared round us. This state of things lasted until four o'clock in the following afternoon, and we groped about purposeless for want of a wind. Once we were nearly ashore, fortunately we had plenty of water under us close up to the cliffs, and we got about in time, but none too soon. When the fog lifted, a strong south-easterly breeze sprang up, enabling us to run into Hitokatpu or Jap Bay, opposite to which we had drifted, and the anchor was dropped for the night close to another vessel, which turned out to be the Flying Mist, of San Francisco. After making everything snug for the night, we were boarded by the skipper, Captain Beckwith, a very jolly old fellow, who told us that he had been on the hunting ground since May Ioth, and had secured 
thirty-five skins, mostly very large ones, some measuring as much as eighty-two inches in length. $\mathrm{He}$ had run across with two American hunters to Honolulu, where they completed their crew with Kanakas. These men make capital sailors and are in much request amongst whalers and sealers, being both active and obedient. The two hunters, brothers, we subsequently met on many occasions, and being accustomed to that terrible product of civilisation, the "whitewashed" Yankee, generally an Englishman or Irishman who has adopted all the vices and none of the virtues of the American character, we were agreeably surprised to find what good fellows they were. As they seldom "guessed" or "calculated," and rarely used bad language, we got to like them very much. They told us that their usual life was duckshooting and punting in the Chesapeake, while in summer they went otter hunting and sealing - a sufficiently hard and adventurous life to suit the greatest lovers of excitement.

The island of Yetorup lies nearly N.E. and S.W. It is about one hundred and ten miles in length, varying in width from about two and a half to twenty miles where the peninsulas on which the mountains of Atosa and Chirituba, respectively 4050 and 5040 feet in height, project almost at right angles to the general lie of the land. The total area of the island is about nine hundred and thirty square miles. Hitokatpu Bay, or Jap Bay, as we always called it, the largest indentation on the south-east coast, is situated about the centre of the island. It is about six miles deep and about the same in width, the two points of entrance lying almost east and west of each other. With the exception of Roku Bay, where we saw our first otter, and which is not marked on the chart, it is the only well-defined bay on the whole of the south-eastern seaboard. It affords but little protection from the Pacific, whose great rolling seas break almost continually upon its shores. A long, low reef of rocks runs straight out to sea from its southern 
extremity, and gives some protection in an east wind if it veer a point or so to the south, but the same amount of variation to the north made it an absolute necessity for us to up anchor and run to the other side for shelter. This, of course, added much to our feeling of insecurity, and the prospect of spending a long day in the boats and of making sail at all hours of the night was not encouraging.

The physical aspect of the whole island is remarkably bold, the dark plutonic rock of gorge and precipice betokening at once its volcanic origin. A range of lofty mountains broken up into eight great groups connected by low flat spaces or broken hills, generally covered with dense primeval growths of stunted timber, extends from north to south of the coast in steep and rugged precipices, against which the waves break with resistless fury in wreaths of foam. Remains of former eruptions are very numerous, easily traced in stupendous precipices and vast masses of rock piled upon each other in endless confusion, while conspicuous cone-shaped mountains, some solid, others mere shells, differ somewhat in external configuration, but all bear evidence of the primitive forces of Nature.

The scene from the deck was very beautiful, though the appearance presented by the country is bleak, sterile, and desolate beyond description. The rays of the rising sun were just beginning to tinge the summits of the mountains ; each peak and ridge grew rosy red, to pale slowly as the orb of day rose higher, leaving by degrees the virgin snow in unsullied whiteness; huge masses of rock hung poised along the steep declivities, which, here and there rent asunder, formed deep and rugged ravines, showing darkly against the lighter tint of the background. While numerous rivulets, now swollen and violent, leapt with impetuous freedom over dark precipices to fall hundreds of feet on to the boulders beneath.

From the skirts of the mountains to the sea, a distance 
of a mile more or less, the country was broken up into mounds and hillocks. The bight of the bay was entirely composed of sand backed with sand dunes, now white with snow, which shielded with protecting care the scanty growth around; the extremities were rocky and boulderstrewn, the east one terminating in a huge unwooded volcanic mountain, the west one stretching out into a spit of raised level ground, like an artificial embankment, terminating in a reef with several kelp beds around it. After breakfast, all hands went ashore to get wood and water, both of which were much needed on board. We hauled the boats up on a little peebly patch, between two small streams that came down murmuring and sparkling, and not far from two substantial wooden houses, the only habitations on the eastern side of the island, one evidently used as a store, the other occupied by a Japanese and two or three Einos; the former told us that they lived for the greater part of the year in the small fishing colony on the west coast, only coming across occasionally to fish during the summer. I had taken my gun, and shot a yellow shanks, but there was little life to be seen. Two large eagles hovering over the scene only added to the desolation, and a few crows, like black dots upon the snow, could be distinguished above watermark, feeding upon some garbage of the sea; a single red-breasted thrush, looking like an overgrown robin, sat sulky and disconsolate on an alder branch behind the houses, and two pretty white-breasted birds, harbingers of spring, sang sweetly, but plaintively, from the wood hard by.

On our return, we boarded the Flying Mist, whose crew, similarly employed, had been working all the morning alongside of ours. We found the ship to be a regular Newfoundland Banker of sixty tons, fore and aft rigged, with large mainsail, the boom running twenty-five feet over the counter, deep and sharp as a yacht, with beautiful lines; no better craft could be chosen for cruising in a deep and sudden-storm-swept sea, in which ability to 
work sharply off a lee shore might at any time make all the difference between safety and disaster.

Next day the wind still blew strong from the south-east, with fog and slight rain, so we employed the morning in filling up with wood and water; at noon the fog cleared away, and, getting the anchor up, we set sail, and were soon scudding across the bay. It was too rough to hunt, so, after anchoring, the skipper and I went to explore the coast, while Snow set off in another boat to try and intercept a couple of bears which we had observed from the deck to be making for the big bluff which terminates that side of the bay. We were all in hopes of a shot, for, if successfully headed, they would either have to come down the coast where the skipper and I were, or take to the mountain side, which is in that part precipitous. Snow, however, was too late, though by following them up he got a shot at the smaller one, evidently a half-grown cub; it fell into the breakers beneath, out of our reach.

The beach, which sloped gradually from a high bank, was entirely composed of hard, white-looking stones, few weighing less than a ton and many as high as a man, but all beautifully smooth and rounded. On reaching the top of the bank we found that a lake, about a couple of miles round, occupied part of the low ground at the base of the mountain, which here stood back at some distance from the strand. The country was densely covered with a species of reed, with laurel-shaped leaves of a green and white, interspersed with stunted pine and cypress. In hopes of getting a shot at some wild duck, we pressed on to the margin of the lake, but found them as scarce as the "black swan" of Latin grammar celebrity. Not a feather did we see, save a couple of white-throated songsters observed on the other side. It was late when we got on board, when we stood over for the other shore and anchored for the night. The fog cleared away early next morning, both wind and sea having abated. An otter was soon sighted, and we were congratulating ourselves on getting sport at last, when 
a heavy sea began to set into the bay, followed by a stiff south-easterly wind, which soon raised such a commotion in the water that we were compelled to return, the sea becoming dangerous. On our way back we boarded another schooner, the Lizzie, Captain Cole, which had anchored alongside during our absence in the boats. Eighteen skins had rewarded the efforts of her crew. In the afternoon we got under way, intending to run down the coast, an example soon followed by the Lizzie, but we found the wind had freshened so much that we were both glad to run back again. The sun shining brightly all day greatly tempered the cold, besides melting the snow, and the scene wore in consequence a less wintry aspect. The following day we started early in the boats, as the wind had died away during the night. Huge glassy rollers, mountains of water, were still coming into the bay, and breaking in a roar like thunder on the beach. We struck across to the big bluff on the other side, round whose boulder-strewn declivities four eagles were hovering, one of which, bolder than the rest, gave a long and unsuccessful shot. A number of fur seals were seen, and five great whales were swimming and diving about in all directions. We saw several otters, but, as usual, the wind sprang up again and, many of the rollers beginning to break far from the shore, made it very risky work, and we were glad to get back safe to the ship.

May 3 oth, the succeeding day, was destined, fortunately, to put an end to our bad luck; we left the schooner at five o'clock in the morning, after a hasty breakfast of porridge and molasses, coffee and biscuit; and, rounding the reef, pulled southwards down the coast. The air was clear and warm, and the sea much quieter.

We had not proceeded far when Snow, whose boat was in advance and who, it may be mentioned here, had, on account of his former experience, been unanimously elected leader in all the hunting arrangements, raised his paddle aloft as a sign that he had "viewed." Sitting down 
quickly and plying his paddle so as to urge the boat onward as near as possible before the otter should take the alarm, Snow presently rose, rifle in hand, and simultaneously with the report we saw the otter's head disappear beneath the wave about two hundred yards in advance. Quickly resuming his paddle, the boat shot forward until over the place where the otter had dived, while the skipper and I took our respective places in the rear. For a few minutes all was eager expectation, the boats, about three hundred yards apart, rose and fell regularly on the glassy sea, while each hunter, with rifle thrown well forward and a face rigid with suppressed excitement, stood erect and motionless as a statute, scanning with expectant glance the sunlit space; even the stolid rowers showed signs of animation and interest in the result. Presently the hissing sound of his escaping breath drew my attention to the otter, which had risen about fifty yards to the right. Quick as thought a bullet splashed up the water near him, as, alarmed by the close proximity of the boat and its occupants, it dived again. Pulling rapidly away, the other two boats advanced so as to bring the spot where the otter had disappeared in the middle of the triangle; another interval, and the otter rose close to Snow, but, instead of diving, it commenced "breaching," while Snow, in full pursuit, took snapshots with his Winchester every time it left the water. The animal tried every artifice to elude its pursuers, dodging now to the right, now to the left; but no breeze ruffled the oily smoothness of the water, and a long train of air bubbles that ascended from the pelt gave as sure an indication of its presence and direction as if it had been seen, enabling the hunter to guide the rowers accordingly. This continued for some time until the otter, finding such tactics useless, dived back, only to emerge near me and go through the same performance, then several more long dives gave opportunities for steadier shots. The chase lasted four hours, most of the 
time being occupied in breaching at a great pace, until eventually the dives became shorter, and longer time had to be taken for getting breath, until a well-directed shot in the head from Snow's rifle put an end to his life, as well as to one of the longest and most exciting chases during the whole of our cruise. The otter, an old, white-headed bull, proved one of the largest and gamest we were destined to meet with. The sun, which was high in the heavens, had become quite powerful, so we rested for ten minutes to give the men time for a smoke and to wipe off the perspiration that trickled down their swarthy faces. Another otter was soon sighted, which, being encumbered with a very young pup, soon succumbed; the maternal instincts aroused by its plaintive wailing prevented her from deserting or, by taking too long dives, from drowning it, until a well-aimed shot put an end to her life and anxiety. This hunt was in great contrast to the first, and was objectionable to all of us as savouring of cruelty. The feeling of a true sportsman is always strongly opposed to the destruction of any wild animal under such conditions, tigers, perhaps, excepted. But the costly preparations and heavy outlay demanded for such work as otter hunting, the continual danger of shipwreck, and the risks run in the boats must not be lost sight of ; while, further, the shortness of the hunting season, the prevalence of gales and fogs give to the sea otter an amount of protection and extent of " close" season which will, I trust, go far to extenuate, if not excuse, a practice universal among those who follow this dangerous occupation.

At mid-day we fastened the boats together, and made a frugal and hasty dinner of bread and cheese, moistened with a bottle each of excellent Bass, the natives stuffing themselves with rice and fish. Luncheon over, we succeeded, after an exciting hunt, in getting another large bull otter, quickly followed by another, about half grown, but with a beautiful skin, the latter just in time, as a stiff breeze sprang up, bringing in its train a thick fog; it was 
now about six o'clock, and, as we were fully twenty miles from the schooner, masts were shipped, and we were soon scudding back under a couple of reefs before the freshening breeze.

Shortly after getting under way Snow shot a small sea-lion about seven feet long which rose before him, the speed of the boat fortunately carrying him alongside before the animal sank. Old Junky, who was in the skipper's boat, licked his lips on seeing the capture, and explained that, next to cormorant, fried seal was the most dainty of dishes. It is certain that the two or three succeeding days gave us ample opportunity of judging the truth of old Junky's observation; and if the power and penetrative effects of the aroma when cooking was any criterion of its culinary excellence, fried seal must be a right royal dish-for those who like it. At all events, it had the good effect of protecting the whole seal tribe more effectually than the most rigidly observed close time could have done. The boats with their three inches or so of keel sailed splendidly; and, well-trimmed aft, did not take so much water aboard as when first tried at Otter Island. The navigation, however, was far from pleasant. In the dense fog we soon lost sight of each other, and, though the compass gave generally the direction, our dependence was principally on the ear to judge the distance from the shore. The constant roar of the giant rollers on our side, and the huge green billows, whose crests became gradually thinner and more over-arching in more shallow water, were our chief, but precarious guides. It was, in fact, ticklish work. The principal difficulty was in the dense fog and the rapidly falling night to round the reef or point of the bay without running so far as to miss the schooner. The turn was successfully accomplished by observing the diminished roar of the breakers. By edging in till the sail jibed we knew that at length we had fairly entered the bay. Right glad we were when the dark hull of the schooner loomed through the fog; and, within ten minutes of each other, the 
various crews of the boats were all on deck as the cabin clock pointed nine.

After dinner, rifles were cleaned and the otters skinned; the latter a disagreeable process on account of the somewhat fetid odour they exhaled. The old bull was found to have four bullets in the body besides the one that finished him. The skin laid out on deck measured from nose to tip of tail six feet five inches, the second bull's six feet two inches, and the cow's five feet nine and a half inches. 


\section{CHAPTER VII.}

A GOOD deal of sea was running on Sunday morning, making the occupations of that day rather unpleasant. Ordinarily, this was the day for writing up the log, mending clothes, casting bullets, etc., a series of light tasks which, we flattered ourselves, did not partake of such a wholesale desecration of the Sabbath as hunting would have been. More important work, however, claimed our attention this morning, for the skins of the five otters shot the day before had been already removed, and required curing, so as to be stowed away ready for the market. The first step was with a sharp knife to thoroughly clear the head, paws, tail, and flippers of all flesh and fatty matter. This being done, rough oblong frames, proportionate in size to the skin to be stretched, were knocked together out of battens about an inch thick and four broad, a supply of which we had handy. On these the skins were laid, and beginning from the head, and well nailed down, care being taken not to stretch them more than was absolutely necessary, so as to keep the fur as close and thick as possible; indeed, much caution was required, the skin being tender, and easily torn. The tail, carefully flattened out, was lastly nailed on to a piece of wood fastened on to the frame for the purpose, each skin, according to size, would require any number up to eighty nails. This part of the operation being completed, the next was to "lean" the flesh and muscle adhering to the under side.

To "lean" a skin properly, one end of the frame is placed on the rail, the other being supported on a cask or trestle. Two people working together from opposite sides 
generally undertake this delicate operation. They are provided with very sharp broad-bladed knives, rounded from the point to a third of their length, the rest of the blade being covered with a couple of folds of canvas, to protect the hand; an incision is made down the middle, without piercing the skin, and the underlying substance removed in opposite directions.

In the afternoon the wind tacked, so we weighed anchor; but as a calm came on we returned to our old position. Monday, June Ist, was as beautiful a day as mortal could desire. Otters were, however, scarce, and we moved farther up the coast at seven o'clock. Hoisting all sail, we were soon bruising through the little sparkling waves as they came curling across the bay under a breeze from the north-west. When abreast of the bluff which guards the northern extremity of the bay, the boats put off to row along the shore, while the schooner proceeded to an anchorage some distance out. This day we only succeeded in getting one otter, a full-grown bull. At noon, the wind went round to the old south-east quarter, but gradually fell away; and by six o'clock, when we returned, it was dead calm. The schooner we found anchored in fifteen fathoms in a small exposed bay, alongside of the Lizzie, whose crew, more fortunate than ourselves, had secured six otters. Our want of success was accounted for by the fact that we had been passing over the ground already hunted by them that morning. Another beautiful morning with a gentle breeze blowing, and a clear, bright sun overhead, enabled us to leave the ship early, with the result that we returned with two full-grown otters, but by eleven o'clock it had begun to blow fresh from the south-west, compelling us to return; and, as there was no shelter should it increase to a gale, we got under way and ran back to Jap Bay. When about half way, however, it fell calm and the boats were again got out, but without success; for not an otter was to be seen. Meanwhile, the sky began to look very threatening, and we returned to the vessel to find the glass rapidly falling, 
and every prospect of a dirty night. Very soon the wind shifted to the north-east, and when at seven o'clock we picked up our old moorings, it was blowing a stiff gale, woollying with a noise like thunder down the mountain gorges.

When we awoke next morning the wind had moderated considerably, but the short seas still showed their white teeth ominously. However, we made an attempt to hunt at ten o'clock, but only succeeded in getting drenched with spray; so we had to return, and sent the boats ashore to get wood and water instead. This was accomplished by the afternoon, when the anchor was hove up, and we were soon scudding down the coast for Sandy Bay. At six o'clock the wind died away, and, as we had been keeping well out to get the full benefit of it, it was with much vexation that we returned towards our anchorage, only to be tossed about all night at the mercy of a chopping tide-rip.

Morning brought forgetfulness of our discomforts and, before the cabin clock stood at six, the boats were lowered and manned, and we were speeding over a glassy sea, lightly fanned by a breeze too soft to ruffle its mirror-like surface. It was certainly a magnificent hunting day; and, before proceeding far, we fell in with a cow otter and pup which were soon deposited in one of the boats. As the day advanced, four more were secured, each one taking us farther and farther down the coast. In considering the matter a few hours afterwards, under somewhat unpleasant circumstances, we concluded that every otter encountered that day had exhibited a malignant desire to entice us as far from the ship as possible. That they had been hunted and disturbed lately was evident ; they took to breaching so much in preference to their diving-back tactics. The last otter, a large bull, was killed at six o'clock, after giving a great deal of trouble and narrowly escaping being lost in a dense fog. This settled down upon us, enveloping land and sea in a damp, dark pall which grew blacker as the night advanced, chilling us to the bone. We groped our way along the 
coast, keeping together and rowing steadily until ten o'clock, when we stopped for the last time to fire off our rifles in hopes of the schooner being within hearing distance. But as there was no response and the men were exhausted, we gave up all hopes of bed and board that night and made for the shore, keeping close in, a curious columnar rock which had been observed by us during the earlier part of the day giving us our position. By this time it was almost pitch dark, for the only light visible was the phosphorescent wave crests as they broke upon the sandy beach. Fortunately, the immense rollers which usually spend their strength upon the coast had melted away with the calm weather, or landing would have been impossible. As it was, already wet through with the fine "Scotch mist" that had been falling all night, there was little objection to jumping out and dragging the boats through the surf. A little groping along the beach, and we had soon collected drift wood enough to make a roaring fire, which added much, in appearance at least, to our comfort. After disembowelling the otters we were too tired to skin, I took a rifle in case we might fall in with a bear-a contingency not at all unlikely, considering the strong scent from the dead otters-and set off with several of the men, two of whom carried torches of dried grass, to obtain wood enough to keep up the fire for the remainder of the night. After topping the bank, the little party found themselves in a small sandy hollow overgrown with bunches of coarse grass. At the bottom the leader stumbled and fell over a log of wood, and this proved to be the topsail yard of a large ship. Tucked underneath, and covered on the outside with earth and moss, was the sail belonging to it, the whole forming part of the side of a hut. These remains supplied the materials for making up a tale of shipwreck and suffering; and judging by the size of the sail, still in good preservation, the vessel must have been a large one, for the canvas was big enough to supply the whole crew with pants. It was not difficult to divine by the dimensions of the refuge 
that the number of survivors must have been few, if more than one. The solemn silence which reigned supreme over the black darkness of the night, the flickering torches which threw their dim, uncertain light around and yet were bright enough to furnish us with these details, which, woven into the web of experience, told an all-too-easily-read tale of misfortune and disaster. Better, surely, to have perished with their shipmates during the few moments of struggle with seething foam and storm-tossed billows than to be cast bruised and helpless upon a shore as bleak and inhospitable as the sea that had rejected them. All inquiries, later on, failed to give us any information about the unfortunate castaways who had never been seen or heard of by the natives; so, probably, like many others who make their living on the great waters, they rest quietly and unknown where their only dirge would be the eagles' scream mingled with the roar of angry waters, which alone unite to break the silence of this gloomy solitude.

We gathered and cut as much firewood as we thought sufficient, and, dragging with us the yard and sail, returned without mishap to the cheery light of the fire. The sail was given to the men, who crawled beneath its ample folds, and doubtless slept; for cannot a Japanese sleep anywhere, and at all times? As to ourselves, we lay down or sat round the fire to pass the night as best we could. The skipper and I had to content ourselves with cutting out our pockets, in which tobacco had been kept, and smoking them, for neither of us could raise a pipeful of the precious weed between us. The fire was carefully tended, as certain unmistakable sounds during the night betokened the presence of bears, which are both numerous and fierce in these parts. After a miserable night of cold and hunger, the first streak of dawn was hailed with delight. A bubbling spring of clear, hot water, which issued from the rocks a short distance from our camp, afforded us the means of washing ourselves, and this added to our comfort. And, after skinning the otters, we made an inspection of the hut and 



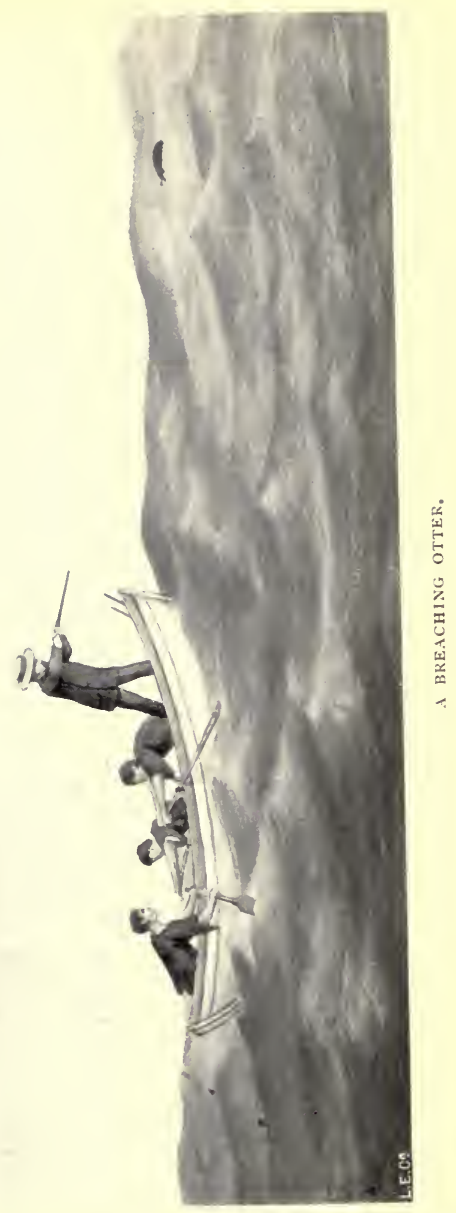


its surroundings, which it was evident now had never been finished. The immediate neighbourhood was carefully examined for anything likely to throw light upon the subject, without success. Subsequent inquiries of the few natives we met, as already mentioned, failed also to give us a clue to the mystery. Without regret, we launched the boats and left the little bay to its ordinary solitude. We found a number of otters swimming about among the rocks, stretching their heads above the water, with looks of astonishment, not yet mingled with alarm. They afforded many a tempting shot, but the rifles were foul and wet, and the caps only snapped; so we left them, for the present, in peace. At six o'clock, the cold rain ceased, the morning fog lifted, and we sighted the schooner; and were very glad of the comforts it supplied. Under the lightest of breezes, by ten o'clock we were anchored in fifteen fathoms of water off Sandy Bay, our destination of yesterday. A good feed partaken of, clothes changed, rifles cleaned, and we were off again in the boats. Proceeding a short distance up the coast without seeing anything, we turned our heads in the opposite direction, in hopes of meeting with some of those otters so numerous in the early morning, but they were gone. Whether it was the want of sleep or the want of better fortune that oppressed us, it would be impossible to say, but without doubt a presentiment of coming trouble brooded over us; and, though nothing was said about it at the time, a proposal made by the hitherto enthusiastic Snow to return to the schooner met with no objection from the rest. While still some distance off, we were surprised to see a steamer round the rocks and anchor a couple of hundred yards from our vessel. Presently three boats put off from her side, and, rowing up to us, took each of us in tow, at the same time putting on board of us an armed marine who, however graceful he might have been in his native dress, looked ludicrously uncomfortable in his tightfitting uniform, for the day had turned out hot and close. 
The last step called for a rather sharp remonstrance, but our protest was answered so politely, that they would tow us to their vessel, that it was useless to resist. Having lived some years amongst these people, and liking them, as we could not fail to do, their vagaries when assuming the manners and dress of Europeans still struck us as very ridiculous; and, aware that we had done nothing of which they could complain, we quietly submitted. It was plain now that this was either the forerunner of that expedition which we had been warned was to take more formal possession of the island and put a stop to otter hunting, or that we were at length to find a key to the obstructions offered to our leaving Hakodate and to the conduct of the Governor of Nemoro. On boarding the steamer, which we had already recognised as the Japanese gunboat Capron Maru, we were shown into a small deck-saloon aft. Seated at a table which almost equally divided it were a number of Yakonins in native costume, and when in one of them we identified the portly form and ill-favoured visage of the Governor of Nemoro, we began to foresee trouble; for, although within our rights in what we had done, it was hardly likely, now that he considered he had the whiphand of us, that he would forgive our high-handed but necessary proceedings at our last meeting, and the small deference paid to his authority.

We were, however, under the American flag, whose prestige is almost as great as that of the English. Its power was as well-known to our captain as to ourselves, and any insult to the one was as sure to be resented as any want of respect to the other. Our apprehensions, too, were allayed by the consciousness that both nations were represented at the time in these regions by two of the ablest ministers ever sent out by their respective governments, and in the course of our examination all our fear subsided. It would be impossible to give all the details of this examination, or rather conversation, for the interpreter's *knowledge of the English language was limited; and, though 
we spoke very slowly, it was easy to see by the puzzled expression of his countenance when he was at a loss. Naturally enough, he did not wish it to be seer, and answered glibly enough, "I understand." To avoid the necessity of drawing on his imagination, our replies to questions were repeated in different forms, and, when all seemed to comprehend, a consultation took place as to what the next question was to be. The following however, is the gist of what passed :

Interpreter: "What are you doing here?"

snow: "Hunting the sea otter."

Interpreter: "Who gave you permission?"

Snow: "Nobody. We Englishmen do not consider it necessary to ask anyone's permission when we sail on the seas."

Interpreter: "You do not seem to know that this is Japanese territory."

Snow: "What! The sea?"

Interpreter: "No; but the Island of Yetorup, where you have been hunting."

Snow: "We have not been hunting on the land, only on the sea."

Here the Governor, quite unaware of our knowledge of their language and who evidently disapproved of the length of the examination, briefly explained to his coadjutors the maritime habits of the sea otter, and further added that the charge upon which we ought to be arraigned should be that we had stolen the sea otters belonging to Japan, and were, therefore, robbers-robbers of the worst description, he added violently.

Poor man! No wonder he was angry, for the few otter skins procured by the natives during the winter with their matchlocks had been a nice perquisite, and to see his monopoly destroyed by these foreign devils was more than he could stand.

Interpreter: "Have you obtained any otter skins?"

Snow (airily): "Oh, yes, thanks, a few." 
Interpreter (delightedly): "Then you are robbers, and we will confiscate your vessel and everything belonging to it."

This made us laugh heartily.

$I$ (sarcastically): "You do not seem to be aware that, even if you own this island, according to international law, your jurisdiction cannot extend beyond three miles from the shore ; and the sea otter is found far beyond that limit."

This was evidently a poser, necessitating another long consultation, when Snow incautiously added, "Besides, you knew we were coming here, we made no secret of it, why did you not tell us at Hakodate? Moreover, I was here last year and met with no interruption; the Governor of Nemoro then," pointing to that exalted functionary, "why did he not warn us if our actions were illegal according to Japanese ideas?"

Interpreter: "When you were here last year did you hunt at all within three miles of the shore?"

Snow: "Very possibly. I certainly did not measure the distance."

Interpreter (joyfully): "Then we will take you toHakodate. The others may go, but having admitted that you may have hunted last year within three miles of our coast is sufficient to show that you have been defrauding the Japanese Government."

This was all amusing enough. But if they had not right they certainly had might on their side, and if they liked to carry out their design it would mean nothing less than the collapse of the expedition, just as the best hunting weather had arrived.

In the whispered council that was held amongst us Snow asked what was to be done, remarking that if they did take him it might, perhaps, be as well, for we should be able to claim heavy compensation for such an unwarrantable proceeding. In this view the skipper was inclined to acquiesce, but I would not. "No, no," I exclaimed, "If you go it will be impossible to hunt with only two boats; 
and you know Baker cannot leave the schooner, and then the cruise will end in disappointment and failure. While as to compensation, that is hard enough to obtain from an individual, but from a government the very essence of red tape, and an eastern one, too, the idea is preposterous. Of course it might be obtained, and very probably it would be, but only at the expense of an amount of patience I, for one, am not at all ambitious to practise. There is nothing like determination in a case like this, tell them you do not mean to be taken away, and trust the rest to fortune, and, if you have to go, we shall be conscious of having done our best."

Snow thereupon turned to the interpreter, telling him they had no right to take him prisoner, for it amounted to that, under any consideration; more especially for anything that he might or might not have done a year ago; and, in short, that he did not mean to go, and dared them to do their worst.

This bold speech, when interpreted, seemed to stagger all but the Governor, who made an insulting remark, the last straw that broke the camel's back; for Snow, whose wrath had been gathering for some time, and who, rightly or wrongly, attributed the annoyance to the Governor's greed, turned upon him and, bursting out into a torrent of reproaches, shook his fist in his face and gave him "such a talking to" as the poor man, unless married, had never received before. All his broken promises, written and verbal, were alluded to in no measured terms, while his motives were canvassed in decidedly uncomplimentary terms. There was no need of an interpreter here, as everything was uttered in Japanese, which we all spoke well. I had been watching my opportunity, took advantage of the consternation created, and whispering to the skipper to keep his eye on the swords piled in a corner behind him and to follow as soon as we gained the deck, took hold of Snow's arm, saying: "Now is the time to clear out," shoved him towards the door. Snow took the 
hint and when two of the Yakonins, who had been seated on our side of the table, rose and seized him, the former turned in a moment and threw one of them prone upon the form from which he had just risen, while I seized the other and sent him staggering into the corner. It is impossible to say what might have happened next, as our blood was up, and our hands almost unconsciously sought the hilts of the hunting knives in our belts, the only weapons we possessed. Everyone had risen to his feet, the cabin was blocked with men, the rifles of the soldiers outside rattled against the woodwork as they strove to look in through the barred windows of the cabin.

Seeing my opportunity in the indecision displayed in not proceeding to further extremities, I called out in Japanese: "You see, this will never do, you must let us all go." Almost simultaneously with these words the interpreter called out: "Stop, stop, we will consider again.". Now it is said that he who hesitates is lost, so we remained in a state of armed neutrality for a few minutes while the usual consultation took place. The interpreter then turned to us and said :

"We shall not take you to Hakodate, but you are now in Japanese waters; if at any time we find you here again, we shall confiscate your vessel and cargo and carry you all to Hakodate; in the meantime, we give you ten hours to clear away, and on no account are you to return."

So far we had triumphed; the interview had been a long one, for it had lasted four hours, it being past seven when we got back to the schooner, after a more than usually exciting two days. The preceding night, it will be remembered, we spent on the sand.

Baker, who had been anxiously awaiting us, had dinner ready, and received with mingled consternation and amazement the story of our bearding the lion in his den, "The Douglas in his lair." He had witnessed our capture, and feared our long detention boded no good. The verdict that we were never to touch the coast again was startling, to say 
the least, but we were thankful matters were no worse. The interpreter's funny mistakes were retailed with much laughter, and the dinner was a merry one. Not knowing whether the Governor might not be able to play us some new trick, it was deemed advisable to place some distance between us; so, taking advantage of a light air off the land which ushered in the night, we hove up the anchor and stood out to sea. 


\section{CHAPTER VIII.}

Soon after our departure we had the satisfaction of seeing the Capron Maru weigh her anchor also and steer towards the south, on her homeward journey. Part of the night was spent in discussing the events of the day and in considering what our future proceedings were to be. However doubtful the issue might be, there remained no middle course, either we could remain on the coast and, trusting to vigilance and good fortune, take our chance, or go farther north where there would be less to fear from molestation. The latter course was open to objections of a more serious character than we were willing to risk, for bad as was the reputation of Yetorup for storms and fogs that of Urup, the next island-to which we might have gone-was infinitely worse; for what with volcanic heat on land and the varying temperature of the waters that washed its shores, Urup seldom doffed its misty mantle; it could rarely be seen otherwise than as through a glass darkly, and it could only be approached at the peril of our safety. Otters abounded, but nature had supplied them with a protection more baffling to the hunter than deepest water or stormy sea. Local storms of terrific violence swept down the mountain gorges, churning the sea into foam, and were by no means uncommon; so that, however numerous the otters might be, the chances of hunting them would be few and far between. Our only course, then, was to remain where we were, and upon this we decided. We were pretty certain that to confiscate a vessel which was hunting or whaling out at sea, but might happen by calms, currents, or stress of weather to be found within a few miles of the shore, 
could only result in making the captors ridiculous, though it might be attended with inconvenience and loss to ourselves. Besides, we were not likely to be troubled for some little time to come, as the coal-carrying capacity of the Capron Maru we knew to be quite inadequate to admit of any long cruising at any great distance from her source of supply, which in this case could not be nearer than Hakodate. Accordingly we determined in future to keep a sharp look-out and trust to fortune; so we turned in for a long rest to make up for our watch of the night before, leaving Baker to work back to the coast and anchor there. But this was to be no easy task, for, long before daybreak, even the light breeze dropped completely, and was succeeded by a dense, wet fog, chilly and depressing; and for the next four days nothing was to be seen beyond a radius of twenty or thirty yards from the vessel. The profound stillness of the air was soon broken by the roar of a tiderip, into which we gradually drifted, to be tossed and tumbled during the period mentioned without intermission, for, having once secured a victim, it seemed loath to give him up. This tide-rip is evidently formed by the pent-up waters of the Sea of Okhotsk rushing through a narrow strait separating Kunashir from Yetorup, and, bending in a north-easterly direction, sweeps the eastern coast of the islands. Its greatest force, exerted a few miles from the shore, overcomes, and doubtless deflects, the course of the Arctic current flowing southwards from Behring's Straits, and it is the meeting of these two currents that causes such a commotion in the waters extending from the south of Roku Bay to the extreme north of the island. Of the former portion we had some experience on our first day's hunting, as has been already narrated, the latter we had yet to encounter. The frequency of fogs is easily accounted for when it is remembered that the difference of the temperature of the two currents is considerable; that of the Okhotsk being warmer, the superincumbent air is soon saturated with moisture, caused by the constant 
evaporation going on, and when brought in contact with the colder current naturally results in its deposition in the. form of mist and rain.

The sun pretended to shine at mid-day, but at best it was a mockery, both as regards light and heat, so raw and dense was the damp air; nor was there any abatement of the rolling and pitching to which we were subjected; not a breath stirred, the masts creaked and groaned, sails had to be stowed, and booms lashed; the cook was at his wits' end, and meagre fare was the order of the day. For three days this state of things continued, without a glimpse of land or sky, and to a position of extreme discomfort was to be added that of danger, for the sullen roar of surf breaking with tumultuous force against the coast, at first faint, grew nearer and more distinct, as we were evidently drifting slowly but surely towards it. Without a breath of air to steer a course, and in a sea too angry and broken to admit of taking to the boats with any chance of safety, our situation was sufficiently alarming. Gradually, however, the roar of the surf grew less audible, and it was evident that we had drifted past some outlying rocks or promontory; but the fog was as dense as ever, our whereabouts still unknown.

The only break in the monotony of the day was caused by me shooting with a short sporting Snyder one of those curious porpoises, called by hunters "puffing pigs" or "grindstones," which abound on this coast. They are generally seen in small parties of from two to six. On a calm day the "puff-puff" as they come up to breathe can be heard at a great distance; and when we were hunting their unlooked for appearance among the boats often brought the rifle to the shoulder, under the impression that it was the otter. We had often tried to shoot a specimen to examine, but they either sank when shot, or their rapid manner of turning over, unlike that of the common species, disturbed the aim, and we never got one. The term "grindstone" is evidently applied on account of this 
peculiarity of revolving on what might be termed a fixed axis. We were now, however, to be more successful, for, coming close under the counter, round which the porpoise had been playing for some time, he offered a good shot, giving me an opportunity of lodging a bullet in its head, killing it instantly. The impetus acquired as he sprang forward and left his life in mid-air carried him some little distance along the surface of the water before he turned his white belly to the sky. He slowly sank, giving us a chance for inspection of his form, and certainly a more ridiculous resemblance to a pig it would be impossible to imagine with his sharp snout and small eyes, while the long pectorial fins placed close to the head supplied a pair of ears to complete the likeness. The upper part of the body was of a shiny black.

A night of great anxiety was spent by all of us on deck, for the roar of the surf was sufficiently distinct to create much apprehension; at any moment outlying rocks might be struck; nor did daylight bring any improvement in our situation, but the reverse. The fog was as dense as ever, while the tide-rip grew worse; hitherto the waves had been broken and pointed, as in a ground-swell; now they became higher, and as we sank in the dark green hollows their attenuated crests raised above the inclined deck would break into a mass of seething foam, which rushed towards the low bulwark with an angry hiss, leaving in its track a snow-white sheet fringed with lace-like spray, beautiful enough to the sight in all truth, but under the circumstances demanding only a passing glance. The rolling of the vessel was so great and so rapid that every moment we. expected her to jerk the masts out of her; the roar of the: surf, deadening the noise of the waves breaking around us, grew louder and more terrible, and our drift towards the ominous sounds more rapid. The lead was kept continually going by the skipper, whose face was more and more eagerly scanned at each "heave," as the roar became more distinct. The boats would have been swamped in such 
a sea-a huge sea, yet no air in motion; all our dependence lay in our anchors, both of which had been long ready, but still no soundings. At length, when all hope seemed to have left us, the tension was removed by the cry, "Fifteen fathoms, let go." Cable was paid out, and as soon as she brought up the lead was lowered to see if she drifted. Fortunately for us the anchor held. The cable, a new one, was as strong as elastic; it gave and took under the severe strain like a spring of steel; held, as it were, on the brink of eternity by a slender thread of twisted coir, which stretched and relaxed with each alternate roll and pitch of the vessel, threatening each moment to snap. With every eye riveted upon it as if it had been the thread of Fate with remorseless Atropos holding the shears, while the stern rose and fell on the very verge of the breakers, whose white foam-covered waters waged ceaseless strife with the precipices of dark, volcanic rock which guard the shore and rise perpendicular from the sea, till, hundreds of feet above, they blend their cold hues with the warm greenery of the dwarf vegetation that clothes the steep mountain sides. Thus passed the greater part of that anxious day. Wet, tired, and sleepy from want of rest, and half indifferent to what might happen-for at the worst we should find the rest we so much needed; daylight would soon be over, and only the darkness of night, now fast approaching, was needed to complete our forlorn condition. But if every cloud may have a silver lining, some fogs at least may have a golden setting, for just as the day was sinking into night and the white mist was slowly changing to a more sombre leaden tint, suddenly and unexpectedly, as if touched by some magic wand, the fog rose in great, cloud-like masses from the water, revealing a wall of black frowning precipices against which the sea broke in continuous wreaths of foam and spray. Driven by the same invisible force, for there was still not a breath of wind, it mounted rapidly upwards, fold upon fold, higher and higher, until, parted by the shoulders of a huge mountain that 
seemed literally to overhang us, it folded its white wings on either side, showing a black breast of rock and precipice, leaving the upper part shrouded in wreaths of trailing mist. But quickly as it ascended, it settled down again as fast, giving us scarcely time to scan the grim and towering rock against which we might at any minute be dashed to pieces ; but that minute was sufficient, Baker recognised the mountain at once with that instinct, common, though in different degrees, both to the sailor and the savage, of remembering a place once seen. The skipper had the bearings taken in an instant, and we set ourselves as patiently as circumstances would permit to wait the advent of a favouring breeze.

As to our position, it was now clear that the current in which we had so long helplessly drifted, after skirting the eastern seaboard, doubled the north-eastern point of the island and swinging round to the left, ran a north-westerly course through the Yetorup Strait, and, still hugging the coast, was carrying us into the Sea of Okhotsk when we finally brought up. Not having time to visit the west coast, it is impossible to say whether this current completely encircles the island; but judging from our drift this theory was not improbable, as we should inevitably have been carried on to the north-west cape had we not been able by the shoaling of the water to anchor in time to save ourselves. The hypothesis that we were under the influence of a powerful eddy setting in shore was contradicted by the tumultous tide-race in which we found ourselves to the very last. It seems evident, therefore, that the current from the Sea of Okhotsk, which passes eastward through the Kunashir Channel, bends to the north, and after washing the seaboard re-enters its parent sea through the Yetorup Strait. Counting from the time when we entered it till we anchored on the edge of the surf, we were drifting for about eighty hours, and reckoning a mileand-a-half for each hour we had moved a hundred and twenty miles. We failed to catch a glimpse of Urup lying 
on the other side of the strait, for the distance from one island to the other, as marked on the chart, must be about twenty miles. Four times within an hour was the windlass manned, but each time the wind fell as suddenly as it rose, and twice more was the anchor off the ground, only to be dropped as quickly, the slight gusts carrying us but a few lengths from our dangerous position. At last the breeze came down stiff and steady from the north-west, and with everything set we ran before it, the schooner burying her nose in the seas and covering the deck with foam and spray. By ten o'clock it was blowing a gale, and at two a.m. when all but the watch turned in, having gained a good offing, we were jogging along under foresail, staysail, and jib on a south-westerly course, heading in the direction of Hitokatpu Bay.

Yetorup Strait, or as it was named in the old charts Vries Strait, is, as already stated, nineteen miles across from Cape Okabets to Cape Nobunots on Urup Island; it is sometimes blocked with ice during the spring.

Urup is sixty miles long with an average width of six miles and is the fourth largest of the Kuriles. It is quite uninhabited except during the summer, and then only by a few fishermen. About half way up the sonth-east or Pacific side is a tiny basin-like harbour where the Russian American Company established a factory in 1795 . It has a depth of eight or ten fathoms, but a heavy swell rolls in with an easterly wind.

There are four principal mountain groups separated from each other, as in Yetorup, by lower and narrower land, and varying in height from 2700 feet to $4{ }^{1} 50$ feet. The northwest coast is the more mountainous side, terminating mostly in perpendicular cliffs dropping sheer into the sea. The Pacific side is much less bold though rocky and precipitous, without any sufficient indentation to be called a harbour, although there are three bays on the Okhotsk side.

The north-east end of the island terminates in a long, flat narrow strip of land about one hundred feet in height, 
which extends from the mountain slope where it is about two miles broad for some five or six miles, gradually narrowing to a point. The last two miles have been breached by the sea, giving it the appearance of a row of steep and rugged islands.

The mountain peaks of black igneous rock are shrouded in snow and mist during the greater part of the year, and it is only on the lower ground that stunted pine, birch, and alder are met with. Great beds of kelp, the favourite haunt of the sea otter, extend along both sides of the island, but the almost perpetual fog makes hunting as precarious as the turbulence of sea and storm render it difficult. The river otter and fox are the only land animals found on Urup, for, unlike Yetorup, there are no bears. Leopard and other seals are numerous and there is a rookery of sea lions at the south-west end close to Cape Nobunots.

My old companion, Captain Snow, mentions in his "Notes on the Kurile Islands," published in 1897 , that the remains of several old wrecks are to be found on the southeast coast. Close to Cape Nobunots on a ledge of rock and boulders beneath the cliffs is a large ship's anchor and some chain-all that is left of a whaler which was lost there many years ago. Towards the north-east end is part of the hull of another, whilst further along the bleached timbers of another may be seen. In the summer of r 89 r a Japanese hunting schooner was lost with all hands on the north-east point.

Things below were in a deplorable state; the cabin table and one of the forms had broken loose and were lying legs up, rifles had been thrown from the racks, and the destruction of crockery considerable; but tired as we were, we were yet more hungry.

It was Saturday night since we had partaken of a regular meal, and this was Wednesday, so the table was refixed, the cook was roused to make hot coffee, and we dined after a fashion on sardines and mixed pickles. The skipper, who naively remarked that he always "went a pile". on hot things, 
"fixed off" a tin of the fish flavoured with a jar of piccalilli pickles and a bottle of Worcester sauce. How delightful to call to mind those grand, healthy, sea appetites, when we got up at all sorts of hours with ready appetites, and when the slightest rattle of a plate or a glass was answered by a voice of the watch on deck down the scuttle:

"Hillo, there, is that you?"

"Yes."

"What are you up to?"

"Grub."

"Hungry?"

"Rather."

"So am I. Hold hard a minute while I look round; get out two plates ; the grog is in the bottom locker."

Presently the skipper's head would emerge from his bunk. "Ha, ha, neatly caught. What have you got there, boys?" Knowing his little weakness, the invariable reply was: "Mixed pickles and Worcester sauce."

"All right, I guess I'll join you. I feel just like taking a square meal. Yank us over the bread."

But, alas! times have changed, and to look even at anything indigestible now is sufficient to draw forth a protest:

"If I were you, dear, I would not touch that."

"Why not?"

"Oh, nothing; but you know if you do you will be as cross as two sticks to-morrow."

Too true. Like Beppo's wife, she might have inquired afterwards, "How's your liver?"

The dirge of the night wind, as it moaned through the rigging, sounded less mournful, and the dismal roar of the waters, as they tumbled ceaselessly too and fro, were like a soothing lullaby when contrasted with our late surroundings. The wind, which had been going down for some time, settled into a light breeze as morning broke, but the fog still held its own; everything was wet and clammy, the cabin felt cold and damp, and, as there was no stove, our wet clothes added to the discomfort of ourselves and our 
surroundings. A glimpse of sunlight was ardently wished for. At noon the air cleared and the land was seen abeam, about twenty miles off, and when at four o'clock we anchored off Gull Island, the wind had died away to a calm, and the fog gathered, but not so thick as before. Gull. Island gets its name from the number of those birds that breed upon it; it is a mass of rock somewhat resembling. Otter Island, and lies a few hundred yards from the shore, a tiny shingly bay offers easy landing, and towards this we were soon pulling in a couple of boats, with the intention of procuring eggs, large numbers of which are generally to be found in the hollows of the low-lying rocks, or amongst the tufts of coarse grass growing in scattered clumps on the tops and ridges of detached boulders.

Our landing was the signal for a terrible uproar among the gulls, almost deafening us with their angry screams, as they darted downwards, or wheeled and circled above us till they darkened the air. Thousands of puffins (Arctica fatercula and Arctica borealis), guillemots (Uria grylle and Uria troila), razorbills (Alca torda), and little auks (Alca alle) flew round the rock in continuous streams from the sea to their nests. Terns (Steroia hirundo) shrieked in sympathy, as with elegant, wavy flight they dipped and rose like gigantic swallows among the angry multitude, and the continued whistling of a thousand wings found a deep bass in the hoarse croak of the puffins. Every ledge and ridge of rocks was crowded with regular lines of snow-white breasts, while from each cave and crevice issued swarms of guillemots and shags. The cormorant alone was absent. A solitary raven soared uneasily above the highest pinnacle of the main rock, at whose base a couple of water-wagtails ran unconcernedly to and fro amongst the seaweed.

There were many nests, but only fourteen eggs rewarded our search, though it was June roth. The main rock being inaccessible, we were unable to overhaul the resorts of the more cunning puffins and guillemots, who, high up in crevices, were beyond our reach, so, after shooting a few 
birds for the men, not forgetting some shags for old Junky, we returned through the fog to the schooner.

It may be mentioned here that very few sea-birds were shot during our cruise. Their extreme tameness was a great protection to them, for it gave every facility for inspection, as there were none but well-known species, and we had no means of preserving their skins, there was no object in wantonly slaughtering them. I always had my gun ready, and made several attempts at forming a collection, but the skins were invariably blown or swept overboard during gales or heavy seas, and I gave up the design in disgust.

The next few days were calm, with dense fog and fine rain, similar in all respects to the weather we had lately experienced. Time hung heavily on our hands, for no hunting was possible; the only distraction from the monotony of life was furnished by the taking of a few codan agreeable change to our diet, cod chowder being a thing of joy. Our principal amusement consisted of visits to Gull Island for the purpose of getting eggs, omelettes being no despicable addition to our bill of fare.

The habits of the numerous sea-birds, too, was a never ending source of pleasure and instruction; I succeeded in shooting a variety of puffin quite new to me. It was black all over with the exception of the cheeks, which were white, legs and feet bright scarlet, the latter each armed with three sharp claws. Being only winged, it bit viciously ; drawing blood several times before it was safely in the boat. The skin, after being carefully removed, was hung on the forestay, but met the usual fate of my ornithological rareties during the next gale. Two small rocky, but flat, islands stretch out to sea in a line, separated from Gull Island and each other by deep channels about two hundred yards wide. The inner and larger one would not exceed a couple of acres in extent; both are continually swept by the sea and are bare of everything but weed, though they afforded a resting place for a large colony of sea lions, who made 
night hideous with their unceasing bellowing. The skipper, whose presence with us was a literal exemplification of the satirical adage so often heard among sailors, "Who would not sell a farm and go to sea," declared that when he closed his eyes at night it was hard to believe he was not at home again among his beloved milk-giving beasts. We found the sea lions when on the rock very shy of allowing our approach within range; but their confidence returned in a great measure when once in the water; they would rise within twenty yards of the boats and suddenly disappear again, giving few opportunities for a successful shot. We were anxious to secure one, and made many attempts at stalking, but they always seemed to sleep with one eye open. I had a narrow escape one day. Rowing in and out among the huge columnar rocks, which fence part of the coast, we came suddenly upon a huge bull resting upon a rock. As, noiselessly, we steered round a bend of the channel, there was only just sufficient time to back the boat from beneath him and no more, before he dived with a great splash from the rock, just clear of the bow. Another few feet and he must have carried us with him to the bottom, as he looked about twelve feet long and of corresponding girth. The whiskers, which are very stiff and long, are much prized by the Chinese, fetching about three shillings each, the small end inserted into a tiny ivory hand is used for the purpose of counteracting any irritation of the skin; a Chinaman would say they are useful for " all the same scratchee."

The sea lion, Eumetopias Stelleri or Otaria Stelleri, after Steller, who in $174 \mathrm{I}$ accompanied Behring in his first expedition as naturalist, is well-named from its leonine dignity and appearance as well as its colour.

It is an immense creature, measuring as much as $12 \mathrm{ft}$. or I $3 \mathrm{ft}$. long, with a girth varying from $8 \mathrm{ft}$. to roft., and weighing I $200 \mathrm{lb}$. to r $400 \mathrm{lb}$. The female or cow sea lion is only about $8 \mathrm{ft}$. or $9 \mathrm{ft}$. in length, but much finer built, weighing only about 4 oolb. to 5 oolb. 
The old bulls fight viciously amongst themselves, being often covered with scars, but are very timid otherwise; the only danger is in getting between them and the water, when nothing will stop them.

Their habitat extends from California to Behring Straits ; but the sea lion observed on the rocks outside San Francisco. Harbour is much smaller, differing in many respects from the more northern species.

The great rookeries are found on the two main islands of the Pribylov group, St. Paul and St. George, where some twenty thousand breed annually. About eighty years ago their numbers were very great-as many as two or three hundred thousand; but, as such great numbers interfered with the breeding of the more valuable fur seals, at the instigation of the Russians the natives hunted and worried them off the land, with the result that the sea lions gave place to the fur seals.

The sea lion is invaluable to the Aleuts, and great store is set by it. The skins, unhaired by sweating, sewn together and stretched over a light framework form their bidarkas and bidarrahs, hunting kayaks and travelling boats; whilst almost every part is made use of for food, oil, or raiment. Several hundred are captured every year by "driving" in a similar manner to that employed with the fur seal, only the operation is a much slower one on account of their size and more cumbrous movements. North-East Point on the island of St. Paul is a favourite place for these drives, the lay of the land being exceptionally advantageous. After September, when the seal rookeries have broken up for the year, fifteen or twenty hunters take up their residence adjacent to the Point. When a favourable night occurs, with a moon partially obscured by drifting clouds and a wind off the land, the hunters proceed to creep along the shore and amongst the boulders until they have gained a position between the sea and the sleeping herd. At a given signal the men leap to their feet, yelling, shouting, and firing off pistols, while the terrified sea lions flounder 


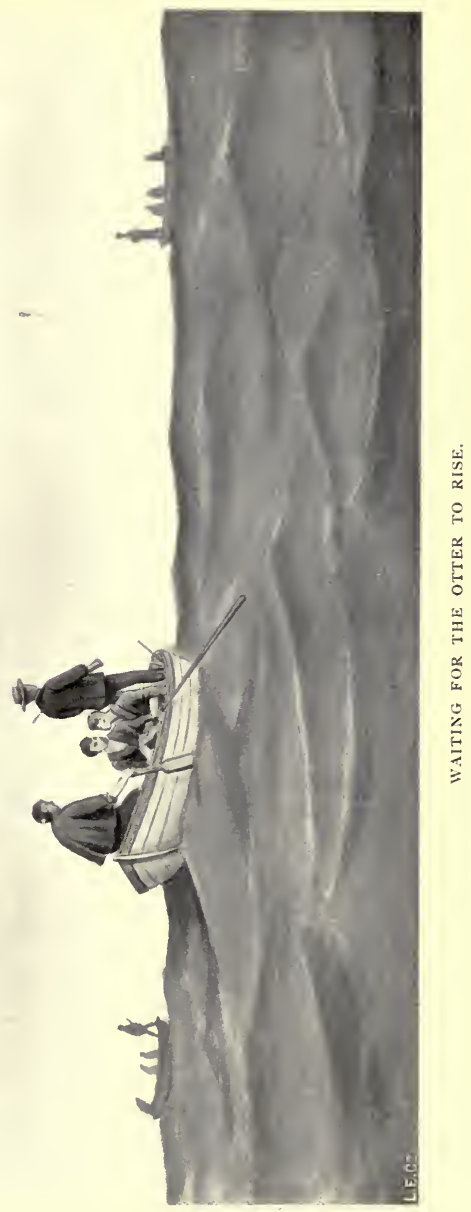



about in all directions. Those which were sleeping with their heads pointed in the direction of the water are inevitably lost, as nothing will stay their stampede seaward, but those looking landwards follow that course just as desperately. These the natives follow up promptly until the terrified creatures fall panting and gasping prone to the earth.

With all sorts of horrible noises and gesticulations they are again and again roused and forced onwards, until they are finally corralled near the hunters' abode. From twenty to forty is the general result of one of their surprises; the corralling consists in surrounding them with a few stakes thrust into the ground some twenty feet apart with a line or two of sinew-rope between them, from which flutter a few rags of cloth. And although they are continually alert, roaring, twisting and twining about, they never make the slightest effort to escape from their flimsy bonds.

When a sufficient number have been corralled by these night surprises-generally from two to three hundred-the great drive commences. With only such pauses as are sufficient to inflate the exhausted lungs of their helpless prey, the natives urge them on with relentless persistence by night and day until they reach their journey's end in the precincts of the village. As this is fully eleven miles from their point of departure, and the rate of progression is only about two miles in the twenty-four hours, whereas the fur seal can be driven at three times that speed, some idea may be formed of the time and trouble employed in these drives. Should the weather be wet and cold, as is generally the case, five or six days is sufficient; but should it be dry and warm three weeks or even longer will often elapse before their destination is reached.

Curiously enough, between North-East Point and the native village are a number of small fresh water lakes, the largest of which is nearly two miles in length, through all of which successively the long drawn-out line of sea lions is driven, without any attempt at escape. 
The track is covered with the bones of the sea lions which have perished during the many drives; for even when very carefully driven, many, exhausted by their unaccustomed exertions, fall out and die ; while with careless and hurried driving the mortality is very great. We were also lucky when the fog was at its thickest in getting a fine bull otter; it was heard mewing, like a huge cat, from the deck, Snow and I with our men quickly dropped into two boats, and, directed by the cries, which continued at intervals, managed to get sight of him, when the former put a bullet through his head, killing him instantaneously. A fortunate haul, for had he once caught sight of us, we should never have seen him again in such weather. Leaving the schooner early next morning, we found the fog, though seemingly as dense as ever, curiously patchy and cloudlike, besides being much thinner on the immediate surface of the water; the range of vision being more extensive from the boats than from the deck of the vessel. Several otters were seen, but only one secured; the others escaping in the gloom, which grew deeper as the day advanced.

We had not gone far on our way back, keeping touch of the shore, when we came across a small schooner at anchor. It proved to be the Buffandeau, of San Francisco; all the boats were out hunting, leaving Captain Sherry alone on board. We went below to have a chat, and the captain produced a jar of liquid, in colour and consistency exactly resembling sulphuric acid, remarking hospitably, as he tossed off his own solution, "Drink hearty, boys, drink hearty," by way of a toast.

Now, the imperative calls of liquid hospitality, so general in the East, which sees in a refusal to poison oneself a studied insult, had at different times brought us face to face, or rather face to glass, with many mysterious productions of the still and the laboratory, such as petroleum champagne, potato brandy, and kerosene gin; but, having experimented with sulphuric acid in our youth, had hitherto drawn the line at vitriolic compounds. Indeed, 
remembrance was so vivid with regard to early experiments that, when the old fellow struck a match upon his pants and proceeded to light a short pipe, we should have felt little surprise had he flamed up suddenly. Even the skipper, versed as he was in the mysteries of chainlightning and forty-rod whisky, looked perplexed. However, there was no escape, and, seeing no signs of volcanic action proceeding from the good man's throat, we took courage and "drank hearty." It was a Mexican drinkI forget the name-prepared from the juice of the cactus, not at all unpleasant, and, considering the rawness of the weather, "very comforting."

Our host proved to be a genial old fellow, and informed us that the schooner was the Buffandeau, thirty-seven tons, and that they had been a month on the coast, and had taken thirty skins. We spent a couple of hours in the cabin, and left at five o'clock, when the fog began to clear again, and after a couple of hours' row reached our own vessel. 


\section{CHAPTER IX.}

AT last, after eight days of white fog, the morning sun rose clear and warm over sea and land, revealing for the first time the beauty of our surroundings. About twenty miles to the north-east towered a huge volcano, round whose shoulders and base dense masses of trailing mist, wreathed in fantastic forms, clung white and cloud-like, slowly to dissipate under the melting rays of the rising sun. The eastern sky, tinged with greenish hue, cast a softened light and colouring upon its solid outlines, and, as cloud after cloud ascended slowly, a mountain mass of dusky heights, with Titanic features and rugged beauty, disclosed itself to our admiring gaze. But high above all rose the cone of the volcano, from which volumes of smoke and steam issued continually, the vapour rivalling in whiteness the irregular streaks of snow which marked its sides like veins of marble. Castellated peaks and tumbled masses of rock in every form lay sharply outlined before us. The coast-line was composed of bold and jagged cliffs, at whose base were huge masses of detached rock standing on end, like giants on guard, while others lay recumbent, forming natural monoliths of form grotesque and gigantic size.

A better day for hunting could not be desired, and, after so long a period of inactivity, our spirits and anticipations were equally high; the latter, however, were not to be realised, three otters only being seen all day, every one of which, in some incomprehensible way, managed to escape. The mid-day sun was very powerful, producing a curious mirage, making both sight and aim very deceptive. The horizon looked like land in the sky, and clouds might easily 
be mistaken for mountains. Curious as this appeared, the coast-line, as we advanced, was equally noteworthy; one cliff would be of bright red sandstone, the next a dark plutonic rock, a third of basaltic columns; some of these last, scooped out by the action of weather above and wave below, resembled enormous shells, and yet, in spite of the accessories of light and warmth, all looked cold and desolate as the dead embers of a fire; it is doubtful if even the vegetation which they lacked would have hidden the many evidences of their volcanic origin.

After lunch, while we were having a smoke before turning back to the ship, the boats about two yards apart, Snow proposed a swim. Sharks of a very large size being fairly numerous, the rest preferred to smoke, but Snow stripped, and was swimming lazily about, when I called out that I saw an otter; but before the former could regain his boat it had disappeared. As the otter was quite close, the boats separated somewhat, and we were all (Snow in puris naturalibus) waiting, rifle in hand, for its reappearance, when to our horror the back fin of a huge shark appeared above the water where our friend a minute before had been swimming. True the shark might not have touched him, but then it might. That the monster could pouch an otter with greatest ease goes without saying. The shark fin most probably had been mistaken for an otter, the dorsal fin bearing a strong resemblance to an otter floating on its back with only part of its head above water. When we left the ship early in the day an otter had been seen and chased till its dives became shorter and shorter, and the boats, not a hundred yards apart, were closing in to dminister the coup de grace when it completely disppeared, and although the boats widened out again and he sea was calm and bright as a mirror, our eager scanning in all directions failed to see another trace of it ; but instead there rose from the spot where it disappeared the back fin of a shark. It may be a libel, but that shark was always credited with having taken a meal at our cost. As the 
refraction, which would fully account for the loss of the other otters sighted later on, had not yet set in, and considering the state of both sea and air, there seems no other explanation for a disagreeable incident; fortunately for our equanimity, nothing of the kind happened again.

On our return we found the little bay full of life and movement. The water was literally coloured with shoals of small sand eels, from three to four inches in length, swimming about in it; more than a dozen large whales were blowing and diving all round us, while albatrosses, gulls, puffins, guillemots, auks, shars, tern, and dusky petrels in their thousands found a rich banquet close to their homes.

After a hearty dinner of cod chowder, prepared by Baker (who had caught the fish) against our return, we lighted our pipes and went on deck to clean rifles and watch the glorious sunset flooding the waters with its golden light. No one could accuse us of being "sick with hating the sun" or insensible to its cheering influence, so little did we generally see of it. But before the purple darkness fell upon the scene an ominous flush of green and orange rose slowly upwards from the horizon and cast a lurid light around, while through the gloomy silence of the night a distant moaning sound floated over the waters till, as it came nearer, it fairly broke into a mournful wail. A glance at the barometer hanging in the cabin skylight showed us, by the rapid falling of the mercury, what we were to expect. The boats were turned over and securely lashed in their places, the storm jib sent forward, the halliards manned, the jib, a medium-sized one and new, unstopped, and everything made ready for putting to sea at a moment's notice should the wind come from any quarter but the north or east; if it came from the north we should be under shelter of the land, if from the east we were protected by Gull Island and it sislets. Fortunately it chose the latter quarter, or o. experitences would in all/probability have been sirnlar to those or itu proceuring week. Comparatively 
sheltered as we were, the wind yet seized the crests of the waves and scattered them in fine spindrift upon the deck. To go below was impossible, as the least shift of wind to the southward would have left no option but to put to sea; so, resigning ourselves to oilskins and our fate, we prepared to pass an uncomfortable night.

The table subjoined gives the meteorological readings during that night and part of the next day :-

\begin{tabular}{|c|c|c|c|c|c|c|c|}
\hline \multirow{2}{*}{\multicolumn{2}{|c|}{$\begin{array}{l}\text { Hours. } \\
\text { IO P.M. }\end{array}$}} & & Barometer. & & \multicolumn{2}{|c|}{ Thermometer. } & Wind. \\
\hline & & $\begin{array}{l}\cdots \\
\cdots\end{array}$ & $\begin{array}{l}29^{\circ} 86 \\
29^{\circ} 83\end{array}$ & $\begin{array}{l}\ldots \\
\ldots\end{array}$ & $\begin{array}{l}50^{\circ} \\
50^{\circ}\end{array}$ & $\begin{array}{l}\cdots \\
\ldots\end{array}$ & $\begin{array}{l}\text { E. by N. } \\
\text { E. }\end{array}$ \\
\hline I & A.M. & $\ldots$ & $29 \% 8$ & ... & $50^{\circ}$ & $\ldots$ & E. \\
\hline 2 & ", & $\ldots$ & $29^{\circ} 77$ & ... & $50^{\circ}$ & & E. \\
\hline 3 & " & $\cdots$ & $29^{*} 76$ & $\cdots$ & $49^{\circ}$ & & E. \\
\hline 4 & ," & $\cdots$ & $29^{\circ} 74$ & $\cdots$ & $4^{\circ}$ & $\cdots$ & E. \\
\hline & ", & & $29^{\circ} 69$ & $\cdots$ & $47^{\circ}$ & $\cdots$ & E. \\
\hline 10 & ", & $\cdots$ & $29 \cdot 66$ & $\ldots$ & $46^{\circ}$ & $\ldots$ & E. \\
\hline & ", & $\cdots$ & $29^{\circ} 62$ & $\ldots$ & $46^{\circ}$ & $\ldots$ & E. \\
\hline & ", & .. & $29^{\circ} 62$ & $\ldots$ & $47^{\circ}$ & $\ldots$ & E. \\
\hline
\end{tabular}

At seven o'clock next morning, while still blowing as hard as ever, and accompanied now with heavy rain, the Flying Mist, less fortunate than ourselves in having been compelled to put to sea on the commencement of the gale, ran in and anchored abreast of us. As evening drew near, the wind moderated somewhat, but still steadily from the east, continued blowing all night. Towards morning it shifted suddenly to the north, rapidly rising to a gale, followed by a heavy fall of temperature; the rain changed to a dense mist, and so cold did it become that our hands were soon half numbed.

In the afternoon a little sloop called the Dolphin ran in and anchored alongside of us. This little craft, only thirty feet in length and nine feet beam, had made an adventurous voyage across the Pacific from San Francisco to Honolulu, and thence up the Japanese coast to her present anchorage. Three rough, grizzled old backwoodsmen comprised her crew, and so small was the accommodation on board, that, 
while two slept, the third steered with one half his body out of the scuttle which answered also for cockpit.

Although splendid shots, their measure of success could not but be of the smallest, being only supplied with one small dinghy. Poor fellows, they were very sanguine, for they fully expected to be able to shoot otters from the rocks, either by waiting for or stalking them; a very delusive hope, as such opportunities, apart from pelagic habits of the sea otter, were rendered almost impossible on account of the bold and unindented nature of the coast. Their fate was a sad one, though scarcely to be wondered at, for only a short time afterwards the Dolphin was found bottom upmost, capsized in some sudden squall. With their bodies immured in the little cabin, the nether limbs of two of the hardy old backwoodsmen could be seen beneath swaying to and fro in the clear water.

In the evening both wind and sea went down, so the skipper and I put off to pay a visit to the Flying Mist, making a detour on our way on the chance of getting some eggs on Gull Island, in which we were fairly successful.

The wind, which for the last two days had swung us clear of the reef frequented by the cod and made all our fishing abortive, had, as we found, quite a contrary effect upon our neighbours, although anchored so near, for they had been having grand sport all day.

We spent an agreeable couple of hours aboard, as the captain and hunters were fine, manly fellows, and gave us much interesting information concerning the sealing on the Island of St. Paul, an occupation in which all at different times had taken part.

The gist of the information received from them has already been given in the more condensed form copied from the U.S. Government Report on the Fur Seal.

With a blue sky overhead and a bright sun shining, the mist still hung tenaciously to the surface of the water, making the air cold and raw as we hove up the anchor, and, under the influence of a gentle breeze, we turned 
southwards and bid good-bye to the scene for a time. On our course we met the schooner, Lizzie, coming in with sixty-six skins.

Owing to the strength of the current and the lightness of the wind we made little progress, and that night we anchored in a tiny bay off some very curious rocks of basaltic character. As the water was shallow, only seven fathoms, with a sandy bottom, we baited for fish; but, in spite of the allurements of fat pork, no fish were caught, though the lines were out almost before the anchor was down. In response to a fine six-knot breeze, next morning saw us early under way, but the wind only lasted an hourand-a-half when the constantly recurring calm, fog, and rain came on till sunset; and when it cleared up we found ourselves, thanks to the current, only a couple of miles south of our previous night's anchorage. Night came on resplendent, with a feeling of frost in the air; the stars glittered with "wintry sharpness." What little moon there was sufficed to set off the stupendous cliffs that heaved their crests high above us in all their rugged wildness; their serrated ridges seemed fashioned into the likeness of a mighty fortress, beneath whose frowning walls and pointed turrets piles of massive boulders, cleft into grotesque shapes, lay prone and shattered, and from the water in front of them rose, unvanquished still, gigantic towers of solid rock, worn smooth by the wild fury of the ever restless ocean. Like giant sentinels they stood, but that night at least their watch seemed over, for nothing broke the sad silence of the gloomy solitude.

Next morning, invigorated by a comfortable sleep, we breakfasted at dawn; and by four o'clock the boats had been lowered and we had left the vessel which was to precede us to Jap Bay. The day proved warm and pleasant, there was no wind to ruffle the mirror-like surface of the water, though farther out we could see the schooner slipping along; but both sea and sky presented that mirage-like appearance which renders shooting so difficult. 
Before long it became evident that however calm it might be inshore, a good stiff gale was blowing outside, for a heavy sea of huge rollers began to heave the waters into great oily swells, putting an end to the surrounding silence as they dashed with sullen fury on the rocks. Otters were more plentiful than usual, though their chance of escape was much favoured by the heavy sea. Lying in a patch of kelp off the great green bluff that forms the eastern boundary of Jap Bay, and just beyond the foam of the breakers, we came upon a large school of about a hundred. The scattering of such a number produced a great deal of desultory firing; the bullet-like heads popping up on all sides presented marks difficult to resist, though, as usual under such circumstances, without result. So we soon settled down to the chase of a single animal; and when, tired and hungry, we boarded the schooner at ten that night, we had five otters in the boat. Eighteen hours in the boats was a good spell, and by the time the skinning, rifle-cleaning, and dining were over it was with a feeling of no small thankfulness that we turned in for the night.

Next morning at six we were in the boats again, beating the same ground. When we started, the day was everything to be desired, but we had not been out a couple of hours when the wind began to blow strong from the southeast, raising a nasty sea upon the tops and sides of the immense rollers - a sea within a sea-a complication which rendered hunting almost impossible. We stood it as long as possible, until, becoming dangerous for our small boats, we were forced to return early in the afternoon with only one otter, which we had fortunately secured before the gale came on. That same afternoon we had a narrow escape of losing another man by drowning. He was stepping in to hook the tackles into the last boat to be hoisted on deck, when he slipped overboard, owing to a sudden sheer. Fortunately, he was a good swimmer, for by the time he was picked up he had been carried both by wind and tide a good three hundred yards astern of the vessel. 
It blew hard from the S.E. all night and next day, when it shifted to the south, bringing up with it a wet mist that increased to a dense fog in the afternoon. All the morning we had been busy repairing the jaws of the main gaff, which had sprung, but in the afternoon we got out the boats and went ashore to get water and wash clothes. As I thought it probable that there might be some trout in the stream we were making for, I took a small fly rod in the boat with me, and was so far successful that in an hour's time I had landed thirty small trout or parr; the greater number were undoubtedly the latter, the produce of large shoals of salmon, known among the otter hunters as "bull trout," which during September frequent the coast for the purpose of spawning in the small streams which flow from the mountains.

The wind went down towards evening, but next day the sea was still too rough for hunting, so we all went ashore again. I took my rod, by special request, the fried fish at breakfast having been pronounced excellent, and was rewarded with forty-two fish in a very short time.

While thus busy, we were interrupted by the presence of two Yakonins, officials from the settlement on the other side of the island. They examined the men, putting many questions, but were very friendly. They were both young men, and at our invitation accompanied us on board the schooner, where they partook largely of port wine, a beverage evidently much to their taste, judging by the manner in which they smacked their lips. The wine, brought for such occasions as the present, had naturally been subjected to an amount of shaking up which imparted a good body to it, but this seemed to detract nothing from its virtues in the eyes of our guests. The great object of wonder, however, was a large mirror, placed at one end of the cabin: they were never tired of admiring themselves in it. I remember being much amused in a similar way when aboard a large vessel off the coast of Borneo. While we were at breakfast one morning a European 
superintendent of police, accompanied by one of his men, a peon belonging to the Ceylon Rifles, entered the cabin for the purpose of identifying some of the officers of the ship, who were supposed to have taken part in a disturbance on the preceding night on shore; after picking out the delinquents, the peon, pointing to a large mirror, proceeded gravely to identify two others, sitting in what he thought was an adjoining cabin.

The Yakonins informed us that they had no objertion to our taking at any time what wood and water we required, at the same time requesting that this should not be mentioned at Hakodate. We promised so much, and as they were getting a little mixed-for, like Cassio, they have poor, unhappy brains for drinking-we put them ashore much pleased with their visit. There are two things, and only two so far as I could discover, that will make a Japanese blush: one is an extra allowance of alcohol in the shape of saki, a rather pleasant, sherry-like drink, prepared from rice and drunk hot; the other is a shell-fish, a kind of clam, and a favourite food amongst the natives.

Having been warned, I never tasted the latter myself, but was with a man once who did, to his cost; for he speedily broke out into an irritating eruption, with feverish symptoms. A Japanese has, consequently, a very admirable excuse to offer for the apparent results of a too-convivial evening- "It was the shell-fish that did it."

In the afternoon, though the fog was still as thick as ever, both wind and sea had abated considerably; so, despairing of better weather, we put off in the boats, and while groping our way about fell in with an otter, which was, fortunately, shot before it had time to disappear in the fog. Though next morning found us stirring as early as usual, it was past eight before the clammy, vaporous wreaths that clung so broodingly over the dark surface of the water began to dissipate. Scarcely had we left the vessel's side, with all the pleasant anticipations of sport, 
which waiting only served to enhance, than a strong breeze set in from the south-east, making hunting as difficult as it was disagreeable. Fortunately the wind did not increase, and at six o'clock, when we returned, we had three otters in the boats. As dinner would not be ready for a couple of hours, I went ashore to fish, taking some of the men with me to get more wood, and succeeded in getting a score of trout, a very pleasant addition to the salt horse that usually graced our table. 


\section{CHAPTER X.}

LEAVING the schooner at five o'clock in the morning, an otter was at once sighted and gave us an exciting chase for over an hour, when, as usual, a dense fog rolled up and under cover of this he made his escape. Our want of luck was very discouraging, nor was it compensated by any success during the day. Several otters were seen, but none secured, for the lumpy sea and saturated atmosphere made good shooting very difficult. The risk of shooting each other also was very great; so, after several rather narrow "shaves" from bullets uncomfortably close, we gave it up and returned to the schooner. That evening we completed our cargo of wood and water-a great advantage, as we were now independent of an anchorage. At eight it was blowing a gale, but under lee of the low-lying point we lay in comparative quiet, and slept soundly after our exertions, unmindful of the wind that alternately howled and shrieked through the rigging. Next day no change in the weather, or prospect of it, so the men were sent on shore to wash clothes, while I fished. At three the fog cleared off, and having caught fifty-seven small trout out of one pool we returned to the schooner and got under way. With all sail set and a steady breeze, we soon tacked out of the bay. But no further progress was to be made that day, for the wind dropped, to give place to fog again, this time accompanied with a fine wetting rain; and we were once more reduced to helplessness. We anchored at midnight, after as nearly as possible going ashore while making short tacks uncler the influence of fitful breezes. Whether we were out of the bay or inside it, we knew not; in fact, the 
fog was so thick that, until we caught a glimpse of the land into which we had been so gaily running, it was an open question whether we had not drifted out to sea.

The greater part of the next two days found us still uncertain as to our whereabouts. The wind had shifted to the opposite quarter, and now blew strong from the northwest, and nothing could be seen beyond a few yards from the side of the vessel. The feeling of ennui created by this enforced idleness was relieved by the fact of our having hit upon a fisherman's paradise; the lines generally relegated to the watch were in constant request, bringing up fine specimens of kelp fish, so called from always being found in the neighbourhood of that long-stemmed, streamer-like weed. The colours of these fish are very beautiful, blue, red, and yellow predominating; weighing generally from three to four pounds, they would doubtless have proved an agreeable variety on table, but cod being equally plentiful, their uncanny appearance caused them to be consigned to the fo'castle. They were probably a species of wrasse. The greatest sport we had was with halibut of huge size, some weighing not less than three hundredweight, and this was not an extraordinary size in these waters. Special tackle had to be improvised for these monsters, as we soon found to our cost. Spare log and lead lines were, therefore, rigged, and the fun began. The bait used, in all cases, was a piece of fat pork. Even with the largest of these fish, a considerable time would elapse from the first seizure to the actual swallowing of the bait; so it was allowed to remain on the ground till we felt certain of our prize. The continual vibration of the line made it an easy matter to tell when one was biting, though he might seem undecided for some time, and, through impatience, many were lost at first by striking too soon. The boldness of the play, however, made up for the timidity of the bite. As long as the head was kept up, it was an easy matter to pull them to the surface; otherwise, nothing would hold them, and it became a question of either letting go or being 
dragged overboard. Our gaff consisted of a three-quarter inch iron hook, securely lashed to one of the boat's masts; a stout rope, reeved through the eye of hook, gave an additional purchase for all hands. The body, being considered too rank, was cut up and salted for the crew; another barrel being filled with the heads, tails, and side fins for our own use; and very good we found them, though decidedly oily.

Towards the afternoon of the second day the fog cleared sufficiently to show us our position, in the centre of Hitokatpu Bay, and so close to the shore as to be very dangerous in the event of a heavy sea setting in. Sail was accordingly made, and we were soon tearing out of the bay before half a gale of wind from the north-west. The strictly local character of the winds on this coast was curiously exemplified as we got outside, for a small sloop, which we sighted about a couple of miles off, was running for the bay with a southerly breeze behind her. Presently there was a dead calm, so we at once put off in the boats, and succeeded in securing two full-grown otters and a pup. We made the schooner at eight o'clock, as she was dropping anchor in a small sandy bay to the north of Green Bluff.

A pause in the narrative must be made here to place on record the extraordinary affection of the sea otter for her young. It is very seldom that she will desert it, as she almost invariably clings to it with the truest maternal devotion to the last. Impeded with the object of her ceaseless care, the long, bold dives for freedom are no longer possible. Hampered with a charge whose plaintive cries strike deeper, deadlier than the hunter's bullet, her sole, unselfish anxiety is centred in her offspring. Sometimes, during the extreme crisis of the chase, the little fluffy ball would be left to its own resources, but none who saw could doubt that this was but the choice of a lesser evil. Warned by the hushed plaint and catching breath, she knows that but a few more dives beneath the protecting 
element and the life of what she loved so well would be taken. And now she is free, at liberty to test her speed against the hunter's skill: but one short mile, only three powerful dives, between her and security. The breeze that brings yon fog-bank down, moving over the waters like a wall of snow, bears to her ear the tide-rip's roar, within the range of whose tumultuous waves experience tells her there is refuge sure. Such might be a temptation of selfish humanity, but her instincts are of nobler order. Hanging on the outskirts of the boats, she seeks, with a boldness foreign to her nature, to lure the hunters from her young; and when at length she deems her ruse successful, back she dives with caution to her nursling's side. The exigencies of our situation and the excitement of the chase might check for a time those feelings of pity which would otherwise have been uppermost, but such unselfish devotion could not but raise within us the strongest admiration.

The night closed in with a clear, bright air and red sunset, the almost certain harbinger of coming fine weather; and the prognostications were not belied when morning broke. As we left the vessel's side a little before four, air and sky were cheering ; indeed, we had never been so favoured since our cruise began.

The outlines of the coast were bold but less regular than usual, being broken with deep ravines and rugged gorges; but very different from the aspect of a month ago, when, unrelieved by any trace of vegetation, save the gnarled and twisted branches of dwarf oak, birch, and alder, the mountain slopes, furrowed by dark fissures and gloomy chasms, looked cold and lifeless : now from a carpet of greenery sprang bush and tree, one mass of leaf, forming a charming setting to the dark mountain background.

About midday we witnessed an exciting spectacle-the attack of several "killers" (Orca Gladiator) upon a whale. The sea being perfectly still and the air clear, we had a capital view of the unequal combat. Some of the "killers," 
of which there might be four, were evidently attacking their victim from beneath, for the whale, a small one, seemed quite unable to dive far, being continually driven to the surface of the water. But no sooner did this happen than sometimes one, sometimes two, of the assailants would spring high into the air, descending upon the whale with the object of striking it with their powerful tails, with a loud thud that might be heard afar; while the sea around the active group was churned into foam. This encounter we now looked upon for the first time, though the unmistakable sounds of such strife were not unfrequently heard. When we arrived upon the scene, we found the whale to be a white one (Balzena albicans), the only one we met with during our stay on the coast. A large white albatross, which was already perched upon its back in anticipation of a feed, flew off lazily as we approached. The whale (whether dead or only stunned we were unable to tell) appeared to be about twenty feet long, without a dorsal fin, skin a pure, shining white. There were no wounds to be seen, nor any sign of blood, although the "killers" are credited with rending their prey in pieces with their powerful teeth; so we drew back a little, and Snow sent a bullet into it, when it sank gradually out of sight without showing the least sign of life.

The beluga, as it is called in Russian, is circumpolar, and it is common in the Arctic Ocean, frequenting the bays on the west coast of Spitzbergen during the summer months in great numbers. It is also found on the north coasts of North America, and on the north and north-east coasts of Siberia in plenty. Many are taken by the natives in the estuaries of the large rivers by placing large, strong nets across the tideways, and then spearing or harpooning them.

The "killer" (Delphinus orca) stands isolated in the order of cetaceans, forming a peculiar group or family among the toothed whales, and, though doubts were expressed by both Scoresby and Bennett as to their 
attacking marine mammalia, later observation has established their carnivorous habits. In a paper read before the Royal Danish Society in 1864 , Professor Escricht gave an account of his own examination of one of these animals; which had been found floating off the coast of Jutland, in the stomach of which, in a more or less digested state, were found no fewer than thirteen common porpoises and fourteen seals; all of the latter were flayed, nor was there any sign of the skins in the stomach, but hanging from the teeth was one completely turned inside out.

It is, therefore, evident that the prey, after being swallowed, is stripped of its skin by the powerful action of the walls of the stomach during the process of digestion, through the rent produced at their capture, and thus the skin is disgorged, like that of the mouse by the owl. This rejection of the skin by the "killers" was observed by Pliny, though his interpretation of the fact was incorrect. For he tells us (Lib. V., caps. 5, 6) that the "orca" which was shut up in the harbour of Istia, where it was attacked and killed by the Emperor Claudius, had been tempted into that part of the sea by the wreck of a vessel laden with hides, on which it had been feeding for several days. What Pliny saw during the incarceration of the animal in the clear water was nothing more than the result of the "killer's" usual habit, and the great naturalist had invented a cause to account for the phenomenon, after the ancient method of deduction.

It is probable that the mistake so frequently met with of confounding the swordfish with the orca in such attacks upon the whale originated with Martens, who was surgeon aboard a whaler in 1671 ; for he mentions having witnessed, during a storm near the Shetlands, a violent struggle between a whale and some "killers" (Schwertfische). The same writer also states that he was informed by the whalers that they sometimes fell in with many swordfish engaged with a whale; that they waited until it had succumbed to its enemies, when they took possession of 
its dead body, of which the swordfish only devoured the tongue.

Now, by the name "schwertfische," the Germans express both the swordfish (Xiphias gladius) and the killer (Delphinus orca), while the corresponding Dutch word, "swaardfisch," as well as the Danish and Swedish "svardfisk," have these two misleading significations. Hence Martens' mistake. The swordfish is neither gregarious nor carnivorous, nor could it devour a whale's tongue. However the mistake arose, it has been perpetuated to the present day, even by Yarrell (Vol. I., p. I44). The antagonism of the "killer" to the whale was well known in early times. Pliny tells us (Lib. X., cap. I5) that when the whales (Balæna) seek shelter in the bays to bring forth their young, the orcas, a species of animal inimical to the whale, chase them on to the shores or kill them in the narrow seas. In the celebrated Icelandic Königspiegel (the mirror of royalty), written in the twelfth century, the only writings of the Middle Ages in which the cetaceans are alluded to, they are thus described:- "In their cruelty against other cetaceans they are like dogs against other animals, herding together and attacking great whales; and where there is only one great whale they bite and weary it out until it gets its death thereof."

The difficulties attending the identification of ocean life, other than that in the capture of which we were engaged, were very great; the strong currents, the generallyinapproachable nature of the shores on which anything might be cast, the frequent fogs and storms, and the continual state of watchfulness necessary for self-preservation gave little scope for such observations. The shore, shrouded in misty vapour, gave no indication of its proximity, a sudden change of the wind would sometimes deceive the ear by deadening in some degree the loud thunder of the surf, and it was only when heaved high upon the crest of some giant roller, whose arching crest and thin green sides told of its approaching dissolution, 


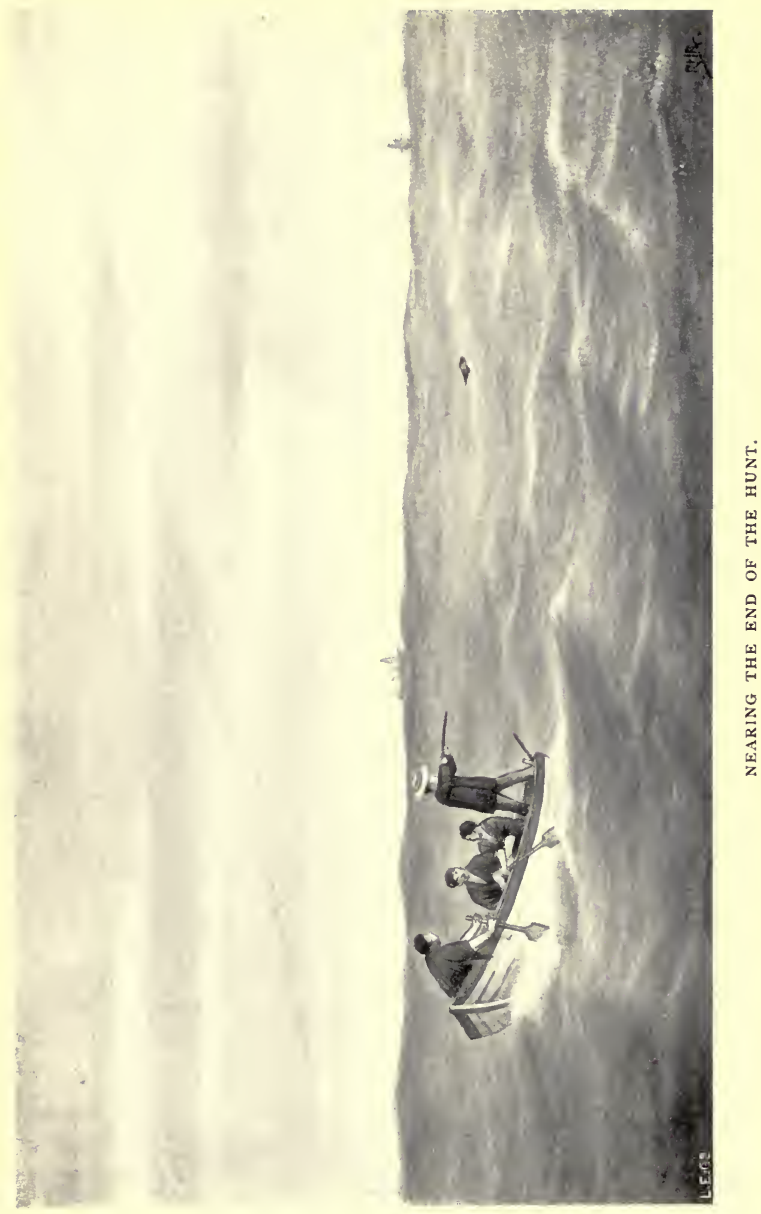



that the peril of our situation would be realised. Sometimes a wave more mountainous than the rest broke seaward of us in a mass of foam, barely giving time to seek the friendly shelter of a kelp bed, or avoid inevitable destruction by a rapid move. At other times there was no kelp, nor could the swallows' rapid flight have cleared in time the extremity of the foamy wall which stretched its snow-white line across the horizon. At such a time there was a period of uncertainty, when the keenest observation was necessary. Balanced upon one of the thwarts, the hunter, with set lips and eager eye, would scan the approaching line, to mark the dark breaks where safety lies, and where the proud wave, exhausted in its strength, fell with its tall crest into the more level expanse to rise no more.

Under such circumstances, it will be readily understood that, presuming the ability, which I am far from claiming, to describe with any pretence to scientific accuracy the different species of cetacea encountered in our cruise would be impossible. I give, therefore, only for what they are worth, such extracts from notes taken on the spot and having reference to such characteristics of these animals as may tend to identification, and which at the time impressed themselves on the mind with sufficient clearness as to be distinctive without my being able to give such detail as would lead to classification. Moreover, the difficulty is enhanced by the difference in nomenclature adopted by naturalists, no two seeming to agree. Unfortunately, this love of change is not confined to naturalists. Poor old Cicero has become Kikero; and even that holiest of holies, the Latin grammar, has been invaded; while even the pronunciation of technical terms finds different exponents in the same classroom.

I shall, therefore, spare the reader as many technical terms as possible, considering that no two treatises as a rule are in agreement upon this point.

The principal whales seen around the coast were the 
humpback, sulphur-bottom, fin-back, and grey whales. They were mostly distinguishable to us, apart from the difference in size, by the height and position of the dorsal fin. But it was the "killers" or orca that interested us most. The length of the smaller species would be from twelve to fifteen feet. From four to eight of them in a gang would sometimes dash in among the half-submerged rocks, evidently on the look out for seals or otters; they would at times surround the boats without showing the least symptom of fear, and almost graze against them. Wonderfully quick and active in their movements, they disappear as suddenly as they present themselves to view, leaving the observer with a sense of relief that he is not the object of their pursuit. We never molested them, though frequently tempted to do so; and, from what I have since heard of their pugnacity, perhaps, as a canny Scot, with true northern politeness, remarked to a friend of mine who apologised for having pushed against him, "It was just as weel."

The second species would be about sixteen to twenty feet in length, with a dorsal fin of from eighteen inches to two feet in height. These animals sometimes overhauled the schooner, ranging themselves on either side, after passing round and underneath it, watching our appearance and movements so carefully as to leave a strong impression that their intentions were by no means peaceable, and that they quite meditated an attack upon what they had, in all probability, taken for a whale. They were symmetrically built with a great deal of white on the belly and sides, and were generally in twos or fours. We were always glad when they left us without giving us much anxiety, for their examination was soon over and they quickly came to the conclusion that our vessel was not the game they sought.

The third species were about thirty feet long and had a dorsal fin of about three feet in height. They were generally met with in pairs; their slower and steadier movements, as they regularly hunted the bays, seemed to 
favour the opinion that they essentially differed from the two species already described. They were perfectly indifferent to the boats, under which they sometimes dived so close as to cause considerable apprehension, for the stake-like fin threatened to shiver our timbers. Whether these whales have a patch of white behind the head, or whether they swim sometimes belly uppermost, it was impossible to say, but a large patch of white could be distinctly seen as they passed underneath the boats. Four of these animals, with twice that number of "humpbacks," were swimming backwards and forwards in the little bay at

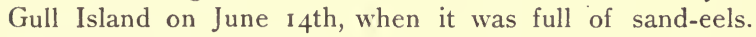
There was then no sign of fear on the part of the "humpbacks," and no sign of aggression on that of the others. As these "humpbacks" have not been mentioned before, it may be stated that they are of great size, from forty-five to fifty feet in length, and that their name, Longimana (long-handed), has been given to them from the unusual size of the pectoral fin, which, in a full-grown specimen, measures fourteen feet.

The fourth species is a much larger animal than any other of the orcas, how much larger it would be difficult to say, but, taking as a criterion of length the extent of body uncovered as it rolled over the surface and comparing it with other whales whose length we know under similar conditions, it could not have been less than forty feet long; its dorsal fin is quite eight or even ten feet high. On a clear, calm day, to see the huge, spiky fin of one of these creatures describe a complete semicircle against the horizon was a curious sight, and one not easily to be forgotten.

With wind and weather, sea and sky all favourable, and last, but by no means least, otters fairly plentiful, it is not to be wondered at that we secured six full-grown otters and a pup; the last was skinned without delay when we got on board, and made into a very appetising curry. Tender as a spring chicken, the only drawback to a delicate stomach being the remembrance of a strong and rather 
fetid odour exhaled by its larger relations, with the hot sun shining upon them in the boats.

Pup skins, after the long dirty-white hairs have been pulled out, make very good caps, the pelt beneath being very thick and soft. I have heard this long hair described as coarse, but this is not the case, examination proving it to be both fine and soft, with a very slight tendency to curl.

Two fine days in succession would have been too much to expect on such a coast, where fog reigns almost supreme; and, even when clear, wind and sea are often adverse to the hunter, so that we were not surprised to hear the wind whistling shrilly through the rigging long before daylight, while the cold, damp air that shot down the companion told the usual tale of mist and rain. But yesterday, what the Portuguese would call a "furious calm," to-day a cold, wet drizzle, accompanied by a fog as thick as a feather-bed. So we spent the morning in dressing skins, and in the afternoon amused ourselves catching albatrosses (Diomedea fuliginosa). We began by throwing overboard pieces of bread and biscuit until we had several of them congregated right astern; the hook, baited with a piece of fat pork, was laid on a small piece of board and floated down among them. A long fishing-line attached gave the sportsman above command of this novel floating fly. There was a rush at this delicious morsel as soon as it was seen, when the sharp point of the hook, catching in one or the other of their strong mandibles, enabled us to drag them on board without injury to anything but their dignity. So tame were these birds, that, by hauling the first few captured quietly along, the rest followed without suspicion until they were right under the counter, so that at last the bait would be seized before it had time to reach the water, and the floating board was no longer needed. When once on deck, like the rest of their kind, they were quite unable to fly, or, indeed, to stand upright for any length of time; and they seemed to be thoroughly aware of their inability 
to do so, but went stumbling and waddling about the deck in a ludicrous manner, snapping their great bills with a loud clack at Rover, who danced around them barking furiously. After watching for some time their ungainly movements, we launched them carefully overboard, where they appeared to much more advantage. Some sailed off in evident indignation and disgust, showing that it was only ignorance that made them so bold, and that it needed only a slightly-extended acquaintance with man to make them as shy as the rest of their tribe; others took their places, grabbing at anything that was thrown to them. Several beautiful boatswain birds, both with and without the handsome swallow-like tail feathers, were flying about, but, as usual, very shy; in fact, so invariably was this the case, that, although anxious to obtain a specimen, they never gave us the chance of coming within gunshot. At six in the evening we shoved off in the boats, and hunted till ten, when we returned with one fine yellow-headed old bull otter. By the time dinner was over and rifles cleaned, boats on deck and everything snug, the cold north-east wind had sighed away its last breath, and the hush of an unbroken calm spread around us. A curious sort of blue film covered the sea, deadening the bright reflected rays of a gorgeous full moon, and raising the horizon till it melted in the sky. Dense banks of cloudy fog flecked the mountain sides and crept across their jagged shoulders in wreaths, jostling against each other as they spread upwards and downwards, till in a woolly white compact body of vapour they capped the outline of the summits in a canopy of snow, and melted the black shadows of rock and ravine, gorge and precipice, into an unbroken scene of wintry white. Below, in strong relief, stood out the jagged coast, with its abrupt cliffs thrown up in rifted pinnacles, or lofty embattled walls and bastions, like some giant fortalice of feudal times, and, still more to heighten the effect, a lunar rainbow stretched its huge arc of coloured light.

Thus ended the month of June, with its twenty days of 
mist and fog, and ten of clear weather; and, of the latter, two were so stormy that hunting was impossible. During the eight remaining we had shot thirty-seven otters, our best day's sport yielding eight. From the foregoing it will be seen how much the elements were against us.

July began with no change in the weather-cold, wet, and fog still prevailing. In the afternoon of the first we put off in the boats, and succeeded in getting an otter with her pup. We returned before dark, and, while skinning our victim, were boarded by one of the crew of a small sloop anchored at a short distance, but which, on account of the fog, we had not observed. He was anxious to obtain a spare anchor and chain to replace one which had been lost a few days previously. After a short time, our visitor left, under promise that his request should receive consideration, and, if possible, we would oblige them. We made up our minds to do so, as, altogether, we had three, when it was discovered that a new knife, which had officiously been taken out of the boatswain's hand to assist in skinning the large otter, had disappeared. The skipper, consequently, went on board the sloop; but, to his inquiries about the knife, all declared that it had not been brought away; he then stated that we could not supply them with chain or anchor. So much for dishonesty. It need scarcely be said that the crew were not Americans; they were composed of the flotsam and jetsam of Yokohama.

Next day the boats put off at dawn, the weather having slightly improved; that is to say, the fog had thinned from the consistency of a feather-bed to the density of buttermilk. But, as will be seen from the brief summary of last month, to go out only on clear days would have reduced our hunting to a minimum. Moreover, the sea otters seemed inclined to keep close inshore during thick weather, so that there was an increased probability of coming across them, without going out to sea, where our own position would be more precarious. So the oars were discarded for the more noiseless paddle; and, moving 
stealthily, we managed to capture three otters as we groped our silent way along the coast. But, all too soon, the atmosphere thickened again, making even this kind of work impossible, and no other course was left but to return. On our way we fell in with and boarded a small schooner, the Flying Eagle, which had run over from the coast of Alaska, and in fifteen months had only taken fourteen otters. The ship's company were certainly labouring under great disadvantages, numbering, all told, only five hands, barely sufficient to work a couple of boats, and quite inadequate to give any chance of success. Some little time afterwards, when speaking of these adventurers to other otter hunters, we learned that one of them was a celebrated shot, it being a common thing for him to be rowed about San Francisco Bay to shoot divers with his rifle, a feat he accomplished with wonderful success. As these birds swim with only the head and part of the neck exposed, some idea may be formed by the reader as to the justice of his claim to be considered one of the best shots on the Pacific coast.

About noon the fog showed signs of clearing, so we put off again. Every minute the air grew lighter, but the reason was soon explained by a series of heavy gusts "woollying" down the mountain sides, and great masses of leaden-coloured clouds rose behind them, with a lookout so threatening that prudence counselled return without further delay. From our constant record of the changes in these latitudes it may be inferred what a variable climate we had to encounter. By tea-time the wind had gone down, the clouds had retreated, and a beautiful calm evening again tempted us into the boats to visit a small bed of kelp that lay off the rocks, but nothing living was to be seen. We landed at the mouth of a little stream born of fog and snow, that tinkled like a silver bell through the thick growth, to discharge its icy water into the sea. We divided and walked a!ong the shore in either direction in the hope of seeing a bear, tracks being numerous, but never a bruin did we meet An undergrowth of rhubarb-leaved plants, 
seven feet high, covered the ground of the forest and extended outside it; to penetrate this was impossible. A few pigeons only were to be seen.

An examination of the pigeons shot proved them to be the variety so common throughout Japan. These birds roost at night in the bamboo groves that usually surround the temple shrines, and very good sport may be obtained during autumn and winter by taking up a position near them, about three or four in the afternoon, and shooting the birds as they return to their quarters. If the priest raises an objection, one has, in common courtesy, to leave; but, as a rule, he is most kind and polite. We used to declare that the pigeons and prawns were the greatest dainties in Japan, the latter grow to a very large size, a length of eight inches not being uncommon (Palæmon). I once watched an old woman catching these crustaceans in one of the creeks in Yokohama by a method quite new to me and worthy of description. There had been a very low tide, leaving the creek a mass of mud, interspersed here and there with small pools of water. After scraping away the soft mud about a couple of inches with a shell, so as to make a circle round her to keep out the water, and exposing the harder sand beneath, she drew my attention (for I had taken off my shoes and stockings to join her) to several small spouts of water issuing from holes in the sand. These she widened with her fingers; and, plunging her hands into a bag suspended from her waist, drew them out with a prawn in each, firmly held by the tail between finger and thumb. These she put over two of the holes, where they immediately sank out of sight. Her object was now evident. The prawn, whose doimcile was thus unceremoniously invaded, at once advanced to the attack, and in a moment was locked in the deadly embrace of the intruder. The old lady, knowing from experience that the moment had come, withdrew her decoys together with their victims, which were quickly shaken into the bag, and the same 
performance was gone through with the next two holescertainly a unique method of prawn fishing.

That morning I had an extraordinarily narrow escape from shooting myself with a muzzle-loading Swiss matchrifle that formed a portion of our miscellaneous armament.

I had been busy in several odd moments fitting a new silver foresight to it, as the elaborate affair with which it was supplied made it quite useless, requiring as it did an amount of manipulation and adjustment only suitable for match-shooting. I had finished my labours and was proceeding to try its shooting from the deck when, for the second time that day, the boats were manned only to return, on account of the weather, and the rifle was hastily put aside loaded.

When the third call came to man the boats, quite forgetting it was loaded, I seized it in my left hand by the barrel, and, grasping the two other rifles the same way with the right, the strap of the ammunition bag being slung over one shoulder, proceeded to gain the deck. With both hands full and the schooner rolling heavily, the only way was to press the rifles close to the body and jam oneself in the narrow companion, and wriggle upwards.

When about half way up, the thought suddenly struck me that the heavy Swiss rifle was loaded, that the muzzle was just under my chin, and if the hammer-head caught in the steps something disagreeable might happen.

The boy was just scrambling over the top of the hatch with the skipper's rifles; so, waiting a moment until he was clear, I threw back my head and eased the rifle back with my wrist. Sure enough the premonition was correct; for the moment the rifle moved the bullet whizzed past my head and scorched my cheek.

Next morning we were early afloat; a gentle breeze was blowing very languidly, as if loth to ruffle the still waters that shone like quicksilver beneath the rising sun. Everything gave promise of a good day's hunting. Still, many a day had dawned as fair, only to change with startling 
abruptness; dense, cold fogs seeming to rise from the surface of the water, as if touched by the wand of some malignant spirit, wrapping everything in their cloud-like folds. Before we had been out an hour, what looked suspiciously like the smoke of a steamer made it advisable to return to our vessel and get under way as quickly as possible. This we accordingly did, having no wish to be caught at anchor within the three-mile limit, after the bother we had had during the preceding month. We stood out to sea for awhile; and, seeing no signs of a vessel, we put off in the boats again at eight o'clock, and pulled down the coast. We found otters fairly plentiful, and had shot four, when it suddenly came on to blow, compelling us to take shelter in a tiny basin, hollowed out of a large rock, that stood some hundreds of yards from the shore. The view from the top was very beautiful, the air being clear and bright. In the distance the lofty blue mountains, scarred and seamed with ridge and ravine, towered here and there in volcanic cones, whose lofty shafts were embroidered with a lacework of snow; while over some a cap of steaming vapour, sign of activity, hung cloud-like and motionless in the still air. The wind, though strong, was unmistakably local. At our feet the sea was studded with half-submerged rocks and boulders of every shape and colour; and these stretched in unbroken confusion till lost in the dark background of gorge and precipice. Over all a death-like silence reigned supreme, scarcely broken by the moaning of the wind as it swept past the storm-riven faces of the scorched and blackened rocks.

Amidst such a scene of desolation, the summit of the rock where we were standing was carpeted with the cranberry, above which rose clusters of large red flowers, poppy-like, but with smooth-edged, elliptical leaves; other plants, too, with long, spear-shaped leaves-both were new to us. But stranger than these seemed the two lovely swallow-tailed butterflies ( $P$. machaon) that flitted more languidly than is their wont from flower to flower. 
Although the sun had by this time attained his zenith, there was a crispness in the air suggestive of fog, accompanied by an increase of cold; and the wind gathered force with a steadiness which promised greater weight presently. Even the butterflies, whose graceful flutterings were watched with childish delight, though sheltered from the wind by a natural parapet, seemed to feel the influence of the damper air. It was time to leave the friendly shelter of the rock, its flowers and butterflies; so, turning our boats homeward, we found the schooner anchored at her old moorings. In a couple of hours after our return, the hazy vapour had cleared off, the wind dropped, the barometer stood as steady as a church, and we were out in the boats once more.

It was ten before we reached the ship, all very tired, but with four more otters-our best day as yet. It was after midnight before dinner was over, as we performed the necessary work of skinning before sitting down to it. The night was warm; almost like a summer's night in more favoured latitudes. A splendid comet, bearing north by west, was sleepily admired; but all hands, except the anchor watch, were soon in their hammocks.

Invigorated by repose, we breakfasted early off porridge and molasses, satisfying if not appetising, followed by some good coffee and a drop of grog. Without delay, the boats put off again at five; sea calm and weather fine. Ere eleven a.m. we had shot four more otters, and were already congratulating ourselves on the prospect of equalling, if not surpassing, the sport of the preceding day when a heavy sea set in suadenly from the south-east, quickly followed by a stiff southerly breeze, which effectually put a stop to all further hunting. We could see Baker lost no time in getting sail on the schooner, her unsheltered position being no longer tenable, for in it she would have to encounter the whole fury of the broad ocean. We ourselves were far out at sea and only caught an occasional glimpse of the white sails standing out in relief against the black cliffs 
as we were borne aloft on the crest of an immense roller. Every minute the wind grew more violent; with sail close reefed we scudded before it for a time, but were soon compelled to keep head to the heavy sea. Presently the wind increased to half a gale, swept off the foaming ridges of a multitude of waves that crested the giant surges, and whelmed us in flying spume. Deep down in the watery valleys, it was a wonderful sight to look upwards from the frail boat that rode so merrily between the dark blue masses that shut us in on either side. There all was calm, but in a moment we rose again aloft upon a sea of troubled waters, to face the gale amidst clouds of spindrift-like life itself from cradle to grave; a rapid alternation of calm and storm, peace and trouble. It was a couple of hours before the schooner beat up to us; and glad enough we were to get on board, change our clothes, hoist and lash the boats, and make everything snug for whatever might come. In the meantime the schooner continued to beat down coast. Towards evening the weather moderated, and we anchored for the night in twelve fathoms off Snowdrop Bay, some distance to the south of Hitokatpu Bay.

It blew hard all next day, so we up anchor at eight o'clock and continued in the same direction for two days, temperature and wind varying, till we felt in our bunks that it was blowing from the north, by a sudden fall of the thermometer from summer warmth to wintry crispness, sharp and invigorating. From this quarter it blew great guns for a whole day, and lightly as the little vessel rose and fell amidst the great seas, the deck was fogged with froth and spray, caught up in blinding clouds by the furious blast. Seaward, as seen between the angry gusts, an ocean lashed into foam, whilst under our lee huge surges dashed in sheets of spray over the black rocks, or rolling into snow, broke in sullen thunder on the strand. When the moon rose the wind began to moderate, and the sea fell as rapidly; so that, by the time we turned in for the night, the wild shriek of the tempest had dwindled to a lullaby as 
it moaned through the rigging, and the splash of the waves a pleasing murmur as they swept gurgling past the sides; bright promise of undisturbed sleep in the present and sport on the morrow.

Early in the morning the Buffandeau ran in and dropped anchor astern of us,

It must have breezed up somewhat during the early morning, for the sea was sufficiently lumpy to make it advisable to have breakfast comfortably before putting off with the boats. By the time we had finished the wind had languished to a breeze, the air was clear though cold, and the sea considerably quieter. Passing Otter Island with its screaming seabirds, without seeing the objects of our quest; we rowed silently down the coast of Roku Bay, the home, par excellence, for chronic fog and tempest. The heavy tide-rip roared a couple of miles outside of us. In any other place a feeling of security would have been present, for the day as it advanced grew more and more enjoyable; the sun shone brightly from an almost cloudless sky, warming the air and flashing on the expanse of mirror-like water, left scarcely ruffled by the capricious breeze, while the scenery, if bleak and desolate, was magnificent. The whole of the south-eastern part of the island is composed of an immense mountain mass, unbroken and unapproachable, terminating in a long line of abrupt, black cliffs of great height. Here and there a margin of sand covers their feet with a patch of colour, but more frequently the quietest sea ripples and splashes against the solid rock, with no line of contrast between the dark water and its frowning barrier. Exposed to the full fury of the broad ocean, the columnar rocks so common on these coasts were here wanting, as if they, even, had yielded to the furious beating of the surge. In such a scene it required the stimulus of excitement in the howling tempest, the rushing, seething sound of foam, the sullen thunder of giant surfs, hurling themselves against the solid wall, and embroidering the black rock with a tracery of froth, to 
banish from the mind that feeling of depression brought on by the contemplation of elements at once so grand in their conflict, so stern in their resistance, so implacable in their persistent onslaught. Long ere their chief descent had been accomplished, such little streams as leapt from the cliffs were dissolved into thin, misty vapours that hung about the bare surface, swaying to and fro under the changing influence of air-currents, and throwing out soft rainbow colours, as though intent on toning down the grim blackness of the fireborn rock.

Fortunately there was no scarcity of otters; indeed, they generally herded here, probably because the atrocious weather secures them from the hunters' attacks. They were well acquainted with their human foes, as they invariably made for the tide-rip as soon as they became aware of our presence. The first one sighted fairly beat us; and although a number of bullets fired at long range splashed around him whenever he rose to take breath, we never once succeeded in turning him or arresting his headlong flight. We lost him in the tide-rip, from which we were only too glad to emerge wet and disappointed. The other otters we chased were either not so strong or so knowing, though most of them adopted the same tactics; but by keeping a couple of the boats well outside, and all far apart, and by being careful not to close in too soon, before their diving powers became somewhat exhausted, we had six full-grown otters in the boats by three in the afternoon. There was every prospect of getting another half-dozen, for the sky was still cloudless, and the sun, which had long ago dried our wet clothes and restored us to comparative comfort, was still shining as bright and as cheerful as ever.

Such signs as in other parts would have lulled to rest the apprehensions of the most weather-beaten mariner were no trustworthy prognostic in Roku Bay. This inhospitable roadstead had little ways of its own, and a reputation-a very bad one-to keep up. 
We were about a mile from the land; the last otter had just been taken on board, and a hurried mouthful of food was being taken-for, up to this time, we had been too busy to lunch-when a low, moaning sound swept over the waters.

Prepared as we were for anything on such a treacherous coast, the boats were quickly cast adrift, and in another minute we were pulling for dear life, with the double object of seeking shelter under the cliffs and of giving as wide a berth as possible to the ever-present dangers of the tide-rip. Already the moan of the wind had swelled into a roar, as it swept down the mountain side, churning the sea into foam and veiling the dark coastline in a cloud of spray. Already we had entered into the vaporous mist raised by the excessive violence of the wind, and encountered the full fury of the blast. The air at once became icy cold, and our faces, burnt up by the powerful sun but just now, were smarting and tingling under a hail of spindrift. Progress was almost out of the question. All our energies were directed to keeping the boat's head on to the wind; but the roar of the tide-rip, rising at intervals between the howling gusts, was a keen stimulus to exertion, and, after a terrible and exhausting pull, the shore loomed up a short distance before us. Then, for the first time, we became acquainted with a peculiarity of these storms, which, though frequently the subject of conversation among otter hunters, we had not yet experienced.

A few more strokes, and we should be under the lee of the high land; but great was our dismay to find that, when but a few yards from the huge wall of rock that towered hundreds of feet above us, the violence of the gusts was as great as when half a mile off. In fact, the wind must have come perpendicularly down the face of the rock. It was particularly noticeable on the little sandy stretches, where the waves broke not a couple of yards out, that the water was caught up and thrown over us in showers. And when at length we turned homewards, still keeping close to the 
shore, the boats were frequently in danger of being overturned by the mad fury of the intermittent blast.

Urup has a pre-eminent and unenviable reputation for this sort of thing, but Roku Bay cannot be far behind it.

It was seven o'clock when we reached Otter Island, where we anchored in the kelp, with every prospect of a night to be spent in the boats. But towards midnight the wind went down; and, after an hour's rowing, we reached the schooner, wet, tired, and half-famished. 


\section{CHAPTER XI.}

$\mathrm{BY}$ the time we had dined, cleaned our rifles, and skinned the otters, but a short time remained for sleep. That which we had was of the soundest; nevertheless, five o'clock saw us again in the boats, pulling up the coast, though the breeze was a trifle strong and the sea consequently nasty. It was not long before an otter was sighted and, after a short, sharp chase, hauled on board, a bullet from Snow's long Kentucky catching him at long range as he topped a wave. Unfortunately, wind and sea began to get worse instead of better, and we were soon forced to take shelter under the lee of a mass of rocks, from the centre of which rose a lofty pinnacle partially covered with bent grass and other coarse vegetation. The base, in extent about a couple of acres, was quite bare even of seaweed, being completely swept by violent seas. A narrow, shallow passage, that afforded a landing, separated the rock from the mainland, which as usual consisted of water-beaten cliffs, shutting off all communication with what lay beyond. To the north several columnar rocks rose tall and grim, and gave a suitable name to the locality-The Pinnacle Rocks.

On this barren spot we passed that and the following night. The boats, carried to the lee side of the big rock and covered with their sails, afforded some shelter from the cold and fog. The days were spent in trying our rifles, climbing, and running to keep ourselves warm. There was no wood to make a fire, or we might have cooked some portion of the old bull otter, however nauseous it might be. Such few gulls as had nests were unapproachable, and our only food consistẹ of wild onions, a fair supply of which we discovered. 
On the morning of the second day the sea had moderated sufficiently to enable us to launch the boats, and, once afloat, we shaped our course to the schooner. As we passed a small wooded gully that descended to the shore we came abreast of a couple of bears-an old one and a half-grown cub. The latter was the first to notice us, and set off with that ridiculous shambling gallop, peculiar to his species, as hard as he could go. After several unsuccessful shots, a bullet from my short Snider caught him through the loins, brought him up with a turn round, and a bullet through the head finished him. In the meantime the old one had succumbed to a combined fusillade of Snow and the skipper, the jerking of the boats making it very difficult to shoot with accurate aim. The old bear had a good deal of white on the breast and shoulders, but the cub was as much white-dirty white-as brown. We wasted more than an hour trying to land, but the sea was too rough. As it was, one of the boats was almost stove in, so we were forced to leave the carcases, hoping to return next day and remove the skins. This, as the sequel proved, we were unable to do; for so favoured were we by circumstances that the bears were quite forgotten until too late to save the skins.

Considering that we had left the schooner in the early morning of the eighth, and it was now afternoon on the tenth, and that we had been living all that time on onions and tobacco, with scarcely a cupful of water apiece, that we were wet through and had had little sleep, it may be easily imagined how eagerly we clambered on board, put on dry clothes, and attacked a substantial meal. Baker had begun to feel anxious about us, and had naturally many questions. to put, but had to defer the gratification of his curiosity till we had stowed away large quantities of food, to which mixed pickles and Worcester sauce added a zest hardly required by "the hungry edge of appetite." Then at length the skipper heaved a deep sigh and "reckoned he felt kinder stiffened up." 
Between this heavy repast and turning in for the night there was no long interval. Wind and sea were both dropping fast; but it is doubtful whether all the accumulated noises of a labouring vessel, with its creaking bulkheads and straining timbers, would have prevented us enjoying that dreamless, health-giving sleep of the weary.

Morning dawned on a magnificent hunting day, with blue sky and warm, clear air. The whole prospect looked more hopeful and settled than we had been hitherto accustomed to expect, and it seemed at last possible to anticipate that summer, real summer, was upon us, to vary with its warmth the never-ending fog and storm that had been our invariable lot-that is, if ever there was summer on this inhospitable coast-a matter on which we had become rather sceptical.

A gentle rolling swell moved over the oily-looking sea which already flashed and sparkled under a glowing sun.

We left the Snowdrop very early, and, keeping pretty well inshore, pulled steadily up the coast. A hoisted paddle in one of the boats soon gladdened our eyes. With everything in our favour the otter had but a poor chance, and was soon lying at the bottom of the boat. Off the mouth of a small shallow bay, dotted with rocky islets, we observed on one of them the remains of a hut, evidently used by the natives of Hitokatpu Bay during the salmon-fishing. Here we came across several otters together. This was rather an unusual occurrence, for, except when a "school," consisting of fifty or more, is met with, they are generally found singly. Our own experience led to the conclusion that the sea otter is strictly solitary in its habits. Even the "schools" are always found in the beds of kelp, immediately following or during the prevalence of very thick or stormy weather. The long, ribbon-like fronds of this species of the algæ act like oil on the troubled waters, and afford the only shelter on this rugged and tempestuous coast. To infer gregarious habits from the fact of finding several together, even during fine weather, would be as unfair as to assign a like habit to the woodcock because a 
number may be flushed from the same cover. Moreover, when disturbed, though they invariably made for the sea, their movements were always disconnected and independent.

Blest with the finest of weather, well-trained crews, and good shooting, the sport was as successful as exciting; and by one o'clock nine splendid full-grown otters lay stretched across the bottom boards of the boats. The chase had led us many miles to sea, and we were apprehensive of the effects of the hot sun upon our cargo, which, strong smelling with a low temperature, was now becoming offensive. So, after a brief lunch, we made for the shore in the direction of the schooner, and boarded at five o'clock without seeing on our way anything worthy of notice, if we except a couple of huge sea lions progressing, with slow, porpoise-like movements, steadily to the southwards.

After filling our water-bottles and tobacco-pouches, we put off again, and killed our tenth otter, the only one viewed, at a short distance from the vessel. Eventually we had to grope our way back through a dense fog, and climbed up the side as the clock struck nine.

This was the best day's hunting we ever had, and will give some idea how remunerative a sport it might be, if the weather were only more frequently favourable; but over their habitat the storm-king reigns supreme, and guards the "Kahlan," in no half-hearted way, from a too ruthless pursuit. Nor is a more extended open time to be desired, for, under circumstances more in favour of man, the result would be the extinction of an animal as interesting as it is valuable. There are already too many instances on record where the lust of slaughter, as indiscriminate as wasteful, has robbed the prairie and the forest of their most useful and harmless denizens.

It was a cheering day for us, though a fatiguing one, and we had worked hard to secure our prizes. We had been sixteen hours in the boats, with a pause barely sufficient for a scanty lunch. For most of the time we had 
been under the strong excitement of the chase; then, again, we had scarcely recovered from the hunger and exposure of the few preceding days. But the satisfaction of success atoned for all, and, with anticipations of a good time of it, we turned into our bunks, not in vain, to seek "Nature's sweet restorer," a dreamless sleep.

With such a record day the week ended brightly, in more senses than one, for not only had we done well, but at last the promise of summer was with us-and surely this was a foretaste of the sport we might confidently expect. Such were our thoughts, that seemed to find their echo in the soothing lap and gurgling ripple of water which, raised by the night breeze, warbled against the outside timbers of our bunks, ere the drowsy god translated us to the land of rest, where neither sun could scorch nor cold winds chill. Such anticipations, alas, how often are they cheated of fruition! Solomon was not the first who had experienced the uncertainty of to-morrow. The promise of the eve was belied by the dirty weather that hung around us as we performed the by-no-means pleasant but necessary duty of preparing skins. And, when this was over, the skipper and I set off in one of the boats to Otter Island, in the hope of getting gulls' eggs ; leaving Snow hard at work in the cabin fitting a new sight to one of his rifles. By keeping touch of the shore, with the peculiarities of which we were by this time well acquainted, we groped our way through the fog to our destination, which lay about a couple of miles due south of our anchorage.

Otter Island, standing about half a mile from the shore, is composed of a mass of Plutonic rocks, rising to a height of nearly one hundred feet sheer out of the sea. Judging by the lines of fracture (originally one), the action of water, or more probably, considering the abundant evidence of volcanic agency in these parts and the burnt appearance presented, some seismic disturbance had first rent and then removed two large masses from the parent rock on the south and east sides, leaving narrow channels strewn here 
and there with half-submerged rocks, amongst which the never-quiet sea rushed with sullen roar and relentless force. The two smaller rocks were quite inaccessible, but the larger or parent mass, about seventy yards long by fifty wide, seemed equally so, with the exception of one place, which we eventually chose for the attempt after rowing round the rock unsuccessfully. The heavy surges, dangerous alike to ourselves and our craft, rendered our efforts abortive, till backing carefully on the top of a wave we sprang out and clambered on to the rock before the boat receded from under us. But our work had only just begun, for the prospect of getting higher was not encouraging. Scrambling along the black ledge for some distance, we discovered a tiny gully sufficient to wedge the body into; and, by taking advantage of this, and hanging on to the strong bent grass which grew in greater profusion the higher we ascended, we managed to reach a less precarious position; our movement upwards was easier, and it became possible to look around us. The ground under us was of a soft, loamy character, covered with long coarse grass, interspersed with a herbaceous plant with leaves like a peony. We found ourselves surrounded with puffins; indeed, the soil was literally honeycombed with their holes, out of which they either suddenly flew, or sat sullenly and defiantly eyeing us as our faces reached the level of their nests. We sank ankle-deep in the undermined soil at every step. At some places, where the ascent was steep, we received knocks on the head from the wings of the startled birds; our hats had long before been swept off and picked up by the boat's crew beneath. We could feel them struggling under our feet as we would be poking away at some obstinate old sitter, in the attempt to get from under her the one dirty-white egg she was carefully guarding. To thrust in the hand and pull out both together might be the simplest way, but he who has once been made acquainted with the strength of a puffin's bill and the sharpness of her claws 
will be remarkably chary of repeating the experiment. One I had winged only a short time before drew blood from the whole boat's crew before we got him aboard the schooner, and then managed not only to beat off Rover, nay, actually assumed the offensive, and hung on beak and claws to anyone who came within reach. After all, the few eggs we did get were hard-set. While searching the lower rocks and ledges we came upon a solitary puffin sitting on her equally solitary egg, in a crevice. After about half an hour's hard work, during which she defied all our stratagems to dislodge her, we succeeded, by dint of sticks, ramrods, string, and handkerchiefs, in securing both her and the object of her solicitude. Amongst the numerous things we raked out of her nest, if such it might be called, was an empty copper cartridge shell of a Henry rifle, and marked "T. and K." I gave it some time afterwards to the chief hunter of the Buffandeau, as belonging to his rifle, and as a curiosity on account of the place where it was found. This man had never landed on this islet, but had repeatedly shot all round it. The puffin must therefore have dived in two fathoms of water to obtain it. Whether carried to her nest as a drinking-cup or a curiosity, "deponent sayeth not." Possibly she wished to test the truth of the adage-"Keep a thing for seven years and you will find a use for it." The skipper inclined to the latter view, having heard of an American who, by wearing the same hat for twenty-one years, had been seven times in the fashion.

This visit to Otter Island was made on July I 2 th, when the greater part of the eggs were hard-set, but we saw no young ones. On the 2 oth of the same month I found a young one in its hole, beneath a boulder, on one of the Pinnacle Rocks, off the south end of Sandy Bay. It was covered with black hair, with a beak more like that of a duck than a puffin, only higher at the culmen. We had on the former occasion brought away four specimens, the examination of which was to enable us to write a 
description. Our observations over and notes being taken, three of them were released, the one detained being destined for the scalpel. The length of wing in this case was fourteen inches, expanse of wing twenty-four, length of beak one and seven-eighths; colour, jet black, with the exception of cheeks, face, and chin, these of pure white. From the top of the head, which was black and velvety, sprang two plumes of golden-hued feathers, from two to two and a half inches in length. They were on either side, immediately over the eyes; the delicate, hair-like feathers, being of varying lengths, gave a gradual taper to these plumes, which drooped gracefully downwards, and were capable of partial erection when the bird was irritated. These plumes seem to be common both to male and female, as, amongst the hundreds seen almost daily, we never noticed any without them. The legs and feet-the latter armed with three sharp claws-were of a bright scarlet colour, rivalling in richness of hue those of the Greenland dove (Cephus grylla) shot at Nemoro. Their usual cry was a hoarse croak, seldom repeated, and their speed when on the wing was almost the same as that of the guillemot (Uria troila).

During the next few days time hung somewhat heavily on our hands, fog without rain and fog with rain alternating persistently. One good day we certainly had, in spite of the fog, which was not so thick as usual. Close to one of the boats rose the first otter, a large bull. His skin, when pegged out, measured sixty-three inches from nose to root of tail. It took us three hours before it was hauled into the boat, the fog baffling us considerably. The air did not clear till seven o'clock, when we got an hour-and-a-half of successful hunting before returning to the vessel, and, as we had bagged in all six otters and a dog seal, we were well content.

One day we went on board the Buffandeau for a chat and a drink of the mysterious Mexican firewater. A hunter belonging to this vessel, who had spent two years 
and a half on one of the Aleutian Islands, informed us that the natives declared the otter to breed at twelve months old. This certainly did not agree with our own observation, for in no case did we see an otter with a pup which was not full grown, though we killed several half-grown ones, about the size of the river otter.

Moreover, we sometimes came across a half-grown pup in company with a cow otter that had a new-born pup between her paws. It is, therefore, probable that the pup remains under its mother's care until it is about halfgrown.

The frequent mention in these pages of bull and cow otters and pups must seem to the general reader, as well as the naturalist, an incongruous nomenclature. But as these are the terms universal among hunters engaged in this wild and strange pursuit, it is as well, perhaps, to ignore the inconsistency, remembering only that those who have bestowed them are, as a rule, as rugged and untamed as the coasts they frequent.

We worked our way gradually up the coast, anchoring here and there, as weather and surroundings permitted, fog and light winds continuing most of the time. Sometimes we left the schooner under fairly promising conditions, but were glad to be picked up half an hour later, to avoid being sunk by one of those local storms which, as fierce as they are sudden, came woollying with terrific roar down the mountain gullies. Independent of the almost everlasting fogs, these sudden storms were, considering the peculiarly shelterless nature of the coast, a constant source of anxiety, coming, as they did, without a moment's warning.

On one side the ocean, with its intervening tide-rips, risky enough to our small boats in a calm; on the other, sandy stretches, cliffs, or boulders, all equally inaccessible. For rare, indeed, was the day when the mountainous rollers, raised by some distant storm, the veriest fringe of whose disturbance scarcely sufficed to fan our drooping sails to 
life, would fail to end their turbulence with thunderous roar upon the coast.

To be blown off the coast in our small hunting boats was a constant danger, although impossible to avoid. But our merry little Japs were as sensible of the peril as ourselves, and encouraged each other with weird cries as they bent their backs and put their staunch little hearts into the oars. 


\section{CHAPTER XII.}

THE third day after leaving Otter Island we reached Jap Bay, about noon. As soon as the anchor was down we started in the boats, the fog appearing less dense than it was outside. We sighted several otters, of which we shot a couple, both full grown, with fine pelts.

Crossing the bay, we skirted the base of Green Bluff; and in a small patch of kelp came upon a school of about fifty. But they sighted us at once, and, startled at our proximity, dived and disappeared in a moment. The few shots fired were without effect, and hunting had to be abandoned, for the fog was getting thicker every minute. So keeping close together, we groped our way back, and were glad when an answering shout told us the whereabouts of the schooner. The following day was devoted to getting wood and water, the chase being impossible on account of our usual obstacle. All hands had a busy morning, but after tiffin the skipper and I went off to try and get a shot at a bear, the tracks of which were plentiful at the watering place.

It was quite a treat to get on shore again; July was drawing to a close, and such flowers and plants as wasted their sweetness on this foggy land should now be at their brightest and best.

The air was warm and genial, and as we left the sea it became clearer and less charged with moisture. We soon emerged from the scanty grass which bordered the stream, and entered a thicket of stunted birch and alder which extended almost to the water's edge. Tall grass, hemlock, and wild rhubarb, with leaves like umbrellas, spreading 
higher than our heads, rendered our progress difficult and disagreeable, and soon drove us back to the stream, a veritable mountain brook, up whose bed we slowly climbed or waded. Here and there were treacherous pools covering quicksands in spits and banks, deposited by the water running in narrow courses, and, but for mutual assistance, we might have come to grief several times.

The bears also seem to have chosen the stream for their highway, judging by the numerous tracks we came across, for at least two she-bears and their cubs had preceded us only a short time before. One must have been a large specimen, for the narrowest part of her fore print was nine inches wide. We kept a sharp look out; for a she-bear with cubs is an awkward customer at any time, but especially in a high-banked stream among quicksands and boulders. As we got higher up the mountain side, we left the fog behind us, and an occasional break in the leafy arcade gave us a glimpse of the sun shining brightly overhead. The trees, mostly silver birch and alder, were festooned with long beards of delicate moss of a yellowish white, looking prematurely old, though scarcely past their youth. There was a monotonous sameness in the size of the trees, nor was the reason far to seek. Prostrate trunks that bridged the stream at intervals, and cast a darkening shade upon the waters, were always those with greater girth, whose very vitality had proved their ruin. Existence in a leaden, socialistic equality was just possible where the rudest wind could only sway the topmost branches; but the vigour which sought a higher level served but to court the full fury of the storm. Unfitted to their environment, those trees which were ambitious to domineer over the humbler sort paid the penalty by a heavier crash. The mountain ash, or witch tree, wiser perhaps in its occult knowledge, bent its gorgeous clusters of white flowers more humbly over the stream. The wild vine and honeysuckle grew profusely, twining themselves round the trunks, or drooping gracefully from the branches; while the homely polypodium 
nestled, half moss-hidden, among the roots. Quantities of salmon parr inhabited each pool; and on our return we shot sufficient for a fry by bringing then to the surface with a bit of biscuit. The natives during September catch large quantities of salmon in the bay, where they evidently come in search of the mountain streams for the purpose of breeding. Though we saw little water running then, large bunches of dry grasses and sticks far above our heads showed how great must be the rush of the torrent at certain seasons. Few birds were either seen or heard after we left the shore, where the uproar kept up by the gulls was continuous. We noticed, however, a redbreasted thrush, looking like an enlarged edition of the robin, which eyed us askance before flitting away to pour out his sweet song from the recesses of the thicket. A bird, probably of the cuckoo species, amused us with its incessant tu-tu, possibly as near an imitation of the correct note as the damp coldness of the climate would allow. A tiny wren, like our golden-crested variety, was busily at work among the topmost branches of a birch tree. Two ravens, perched upon the highest sprays of a dead cedar, eyed us suspiciously; and if we mention a small bird like the white-throat, our list is complete. On our return to the boats, large numbers of pigeons, almost exactly resembling our stock dove and similar to those common throughout Japan, were busily feeding upon the larvæ of the sand hopper, amidst the sand and seaweed of the high-water line.

The following day being too foggy for hunting, we went ashore in the morning to shoot pigeons, which we found an agreeable change from salt-horse and tinned provisions. In the afternoon, Baker and I landed with our rifles to look for bears; but only saw one half-grown, and this took to flight from some cause we were unable to discover, for we approached very cautiously. We came upon the eyrie of a pair of white-tailed eagles ( $H$. Albicillus), but the nest was as usual inaccessible. The old birds circled round and 
round us, screaming loudly, but generally keeping at a respectful distance.

By hiding under the overhanging ledge of a detached rock, while Baker withdrew for a short distance, I got a steady shot at the male bird as he sailed overhead on outstretched wings, and sent a bullet through its breast. We had some difficulty in finding the body in the long grass, which grew in rank luxuriousness as high as our shoulders, until Rover came to our assistance and soon showed us where he was. I could see little, if any, difference between it and our Scottish white-tailed eagle.

Returning we made up a large bunch of flowers, which brightened up the cabin for some days. Sweet peas, sweetly-scented wild roses, yellow lilies, and iris composed our bouquet. There were also some tall flowering plants, six feet high, in full blossom, resembling the balsams so common in every little English greenhouse.

In passing Onabetzu, as the fisherman's house at Jap Bay is called, we found several Japanese fishermen drinking saki, and decidedly hilarious. Some were dancing, a bad sign, if Cicero is correct that "no sane man dances unless he is drunk." They were very hospitable, and insisted upon us joining them until our boat arrived from the schooner. But drunkenness, even when hilarious, is repulsive, especially in such a wild and desolate scene, so we were glad to divert their attention by putting up a mark and firing at it with their primitive matchlocks.

We made fairly good shooting at close range; but their powder was execrably bad, and the bullets none too spherical. Baker literally brought down the house when, with a bullet from his own rifle, he doubled up a seagull sitting about a hundred and fifty yards off upon the shore. We embarked amidst a chorus of admiration and applause.

For five long days we were compelled to stick to our anchorage, without the slightest chance of hunting; for there was not a breath of wind, land and sea being literally blanketed in fog. And right glad we were when a good 


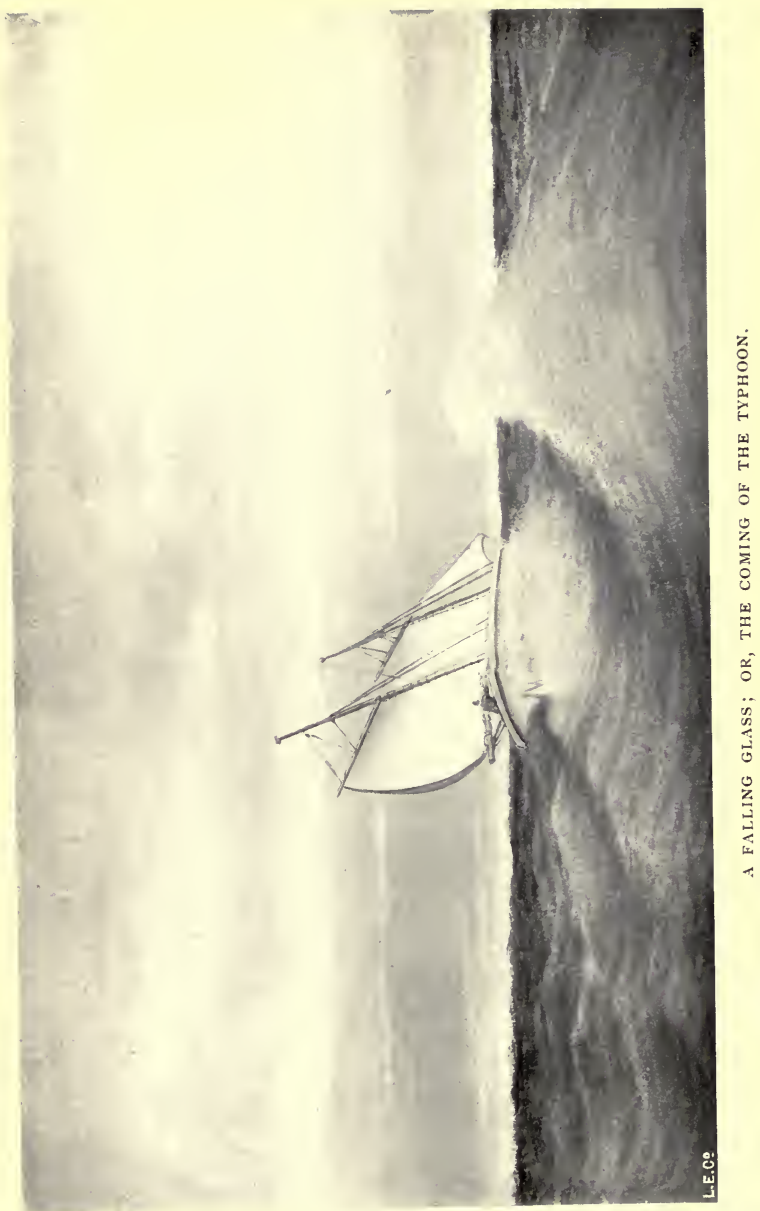



southerly breeze sprung up, which changed into a strong north-easterly wind before we could get the anchor up. So strongly did it blow at times that it took the greater part of the day beating out of the bay, and it was only late in the evening when we ran down the coast, anchoring in eighteen fathoms in Sandy Bay.

The following day, although still foggy, we got five fullgrown otters, and during the next two days six more. Most of our successes were owing to Snow's good shooting, as, using our paddles, we noiselessly stole upon the otters in the fog, and shot them before they could take alarm and dive out of sight, chasing with such an atmosphere being an impossibility.

But at last there dawned one of those rare and muchlonged-for days when the fog was only intermittent, and the sun blazed down upon us with almost tropical violence. The sea was like glass, and a more beautiful hunting morning could not have been desired.

We left the schooner at six o'clock and did not get back until after nine that night. Otters were plentiful, especially in the kelp bed off the westerly point of Hitokatpu Bay. The boats of the Myrtle were hunting there also, but we were all too busy to speak to each other. Many of the chases were long and fatiguing; and when we returned it was with seven otters and a pup, not to mention sunscorched faces and arms, and good appetites. How gladly would we have turned in to our bunks; but rifles had to be cleaned and otters skinned, so that we did not get a chance of dinner until midnight.

A few more days like this, sunny and fogless, with a calm sea, and what sport might have been ours! But in that case the otters would either have deserted the coast or been almost exterminated.

Many seals were seen, both "hair" and "spotted" ; one of the latter, a leopard seal, spotted like a Dalmatian dog, was shot, but unfortunately sank before we could get up to it. Many were the lamentations amongst our men, 
especially old Junkey, who had been licking his lips in anticipation of a square meal; but it was a great relief to ourselves, for the smell of roasting seal throughout the vessel was a thing to be felt. Of course, after such a day, the two following ones were densely foggy; and, though we groped about aimlessly in the boats, only one otter was seen, though not bagged.

Thus ended July, with its twenty-five days of storm or fog, the boats being only able to hunt at all during twenty of those days, often only for a few hours, on account of stress of weather; while the sole three clear days, when almost continuous hunting was possible, produced respectively eight, ten, and eight otters.

The coming of August had been eagerly looked forward to as the best month for hunting; for surely in the height of summer-if, indeed, there were such a season on this desolate coast-some slight cessation of dense fog and cold rain might be expected. But we soon found that such few flowers and fruits as were able to exist amidst such a bleak and humid atmosphere seemed only to bloom and ripen as Nature's protest against the surrounding gloom, instead of being, as we thought, the signs of summer.

The continuous struggle between the Arctic waters that swept the coast with endless force and the warmer currents from the Okhotsk, or further south, which were hurrying with equal persistence and energy to the north, flowing at times past each other in deceptive silence, at others seeking conflict with angry crests upheaved in the roar and struggle of the tide-rip, could scarcely be conducive to anything like stability in the atmospheric conditions. Add to these the colder and warmer strata of air they carried with them on their surfaces, and supplement all by the hot fumes of boiling springs and volcanic blasts that used to sweep over the boats at certain parts of the coast like breaths from a furnace, and it can easily be understood how small was the chance of even the most elementary 
of summers asserting itself. Such conditions of continual conflict could only be productive of fog, rain, and sudden storm.

On August ist we left the schooner very early in the morning, having deserted our last anchorage a couple of days before, beating slowly up the coast amidst fog and light airs from the north and anchoring beyond Hitokatpu Bay, in what we called Hot Spring Bay, on account of a number of hot springs that bubbled up out of the sea some distance from the shore, which they enveloped in steam. A lucky shot bagged an otter not a couple of hundred yards from the vessel; but we failed to see another, and, as the fog grew denser, we landed at noon for a couple of hours beneath the great bluff that guards the eastern extremity of Hitokatpu Bay.

So steep was the mountain side as it rose from the sea that it was only by using our sheath knives that we were able to climb for a short distance to pick some of the cranberries and flowers that grew in profusion on its side: pinks-not sea pinks-yellow lilies of two kinds, bluebells, and yellow iris.

As the fog cleared a little we started again on our return, and were successful in shooting three more otters before we reached the schooner at seven o'clock.

Weighing anchor next morning, we sailed and drifted up the coast under slight and intermittent breezes, and brought up for the night not far from Gull Island, but did not leave the schooner, as the fog was very dense and we were anxious to get further north if possible.

After a quiet night we got off early next morning, but did not leave the vessel until later, when we were opposite the curious basaltic rocks which had excited our curiosity so much when we had first seen them nearly two months before. We rowed a long distance down the coast, but only saw two otters, one of which we shot. The day turned out better than we expected, as the fog grew thinner towards midday, and there was scarcely a breath of wind. 
As no otters were to be seen near the shore we sought the rougher water a few miles out, but the tide-rip was very dangerous, besides making accurate shooting very difficult. Standing up on the thwart of a little cockle-shell of a boat which was pitching and tossing in all directions is not exactly conducive to good shooting, especially as the otter when hard pressed or much hunted invariably made for the most turbulent water he could find.

We got back at five o'clock to find the schooner, although unanchored, in almost exactly the place where we had left her.

This was fortunate, as the fog had by this time settled like a pall upon us. In thirty fathoms of water, with the roar of the tide-rip on one quarter and the thunder of the great Pacific rollers on the other, our position was not a pleasant one. While the senst: of helplessness so characteristic of these dense, opaque fogs accentuated the feeling of insecurity. Fortunately, before it got dark a slight breeze sprang up, sufficient to enable us to run in close to the big hollow rock and anchor in seventeen fathoms.

It was nine o'clock next day before the boats got away, and, taking an easterly course, we rowed about half-way up to Gull Island. We saw eleven otters altogether; but, on account of the thick atmosphere, were never able to see more than fifty yards ahead. Nor, of course, could we see each other, but being a dead calm could occasionally hear the sound of the oars. We managed to get two otters and a pup.

We spent the next two days under a pall of dense fog, cleaning and airing the skins already stretched, "leaning" others, and overhauling ropes and rigging, it being quite impossible to leave the schooner. 


\section{CHAPTER XIII.}

BuT August 6th was to be a red-letter day, being bright and clear from almost dawn to dark-one of those days we were always hoping and praying for, but which came so seldom.

We left the ship at six, after a hurried breakfast. The dense mist that had enveloped us for the past two days was disappearing fast, and the sun, clear and bright, shone through the cloud-like vapour with ever-increasing force. The depressing effects of living for days and weeks enshrouded in gloom, sometimes without a sound except the weird cry of a sea bird, often ignorant of our position or proximity to the scarred and rugged rocks that sentinelled a coast as storm-beaten as themselves, was dissipated in a moment, as soon as Sol turned his warm and almost forgotten old face upon land and water.

When at mid-day we drew the boats together to have our lunch of biscuit and good old salt-horse, we had got six full-grown otters, most of which had led us a merry dance over the glittering water. Our arms and faces, which had begun to lose their tan, were smarting with the reflection from the glassy water.

Before we were finished we were joined by the six boats of the Flying Mist and Otsego. Both were manned by nice-looking Kanaka boys, which they had picked up at Honolulu on their way from California. Our own little Japs looked small beside them, except old Junkey, with his hard-weather face, who towered above them. But their little bodies had strong arms and legs, while their neverfailing good humour, tireless energy, and amenableness to 
control had long ago endeared them to us all. Behind the merry faces lay a fund of dogged determination and absence of fear or panic; no wonder they make the best and pluckiest pearl-divers in the world. What men for a navy! And what a supply, when half the population on the great coast line spend their lives as fishermen upon the great waters. Kind and gentle to women and children, rarely quarrelling amongst themselves-we ourselves never had a sign of a row during our cruise-where every coolie is a gentleman in his manners, and yet a sturdy, warlike race-surely they will go far in this Britain of the East.

Both the Flying Mist and Otsego had been hunting off the Island of Urup for a short time, but without much success, having only got twenty-six pelts between them. Dense fog and fierce wind storms, worse even than we had experienced, were of almost daily occurrence. They had also noticed, like ourselves, in the difficulty in attempting to land for shelter during those fierce and sudden blasts, that woolly down gorge and mountain sides, the curiously unsheltering nature of the coast.

The storm-tossed coaster, with every stitch he can carry, does his best to work up under the shelter of some embattled cliff, knowing well that under its protecting lee lies quiet water and a tempered gale. But in these seas his efforts would have been valueless, for he might as easily have had his sails split within biscuit-throw of the land as if he had encountered the full fury of the storm in more open water.

When the crew of the little Geordie brig, consisting of skipper, mate, and boy, were drinking the usual Saturday night's toast of "Wives and sweethearts," in much perturbation of mind (for they had temporarily lost sight of land), the mate remarked, sadly,-

"I wonder if they know where we are to-night?"

The skipper replied, tersely,-

"I wish to God we knew ourselves, Bill."

It is probable that the north-country skipper, in our 
position and with our experience, would not look as longingly landwards as he is said to do.

It seemed as if the screaming blasts tearing down the hillsides met some denser and almost rigid stratum of air which deflected its fury and hurled it downwards along the face of the cliff, until it struck the waves beating against the shore and whirled their broken crests into a cloud of foam and spindrift.

Up to this time the Flying Mist had obtained eightyseven skins, and the Otsego forty, against our one hundred and thirty-three.

The day was too good to be lost, so after a hasty lunch we parted from our companions and recommenced our hunt.

We got back to the schooner at about nine that night with ten full-grown otters in the boats-with smarting, sunburnt faces and arms, but in good spirits.

A tired crew-ten otters to skin, three rifles each to clean, as well as ourselves, and dinner to take, kept us busy until past midnight. Thus ended one of our three red-letter days upon this coast, which had been really clear and bright from sunrise to sunset. Such a day is instructive as showing what sport might have been obtained had the weather only been favourable more frequently. On the other hand, what is good for the hunter is seldom so to the hunted. Man is a strenuous creature, meeting dangers and difficulties only to overcome them, while they add to the joy and fascination of the sport. But on those occasions when, unable to reach the vessel, we had to spend cold and uncomfortable nights coiled up on the bottom boards of the boats, wet and hungry, sometimes even without the solace of tobacco-for it is just at such times that the supply gives out-one could not help thinking that a few such nights went a long way, and the more seldom they came the better. "Rocked in the cradle of the Deep," especially if heard from the recesses of a comfortable armchair, is a soothing melody, implying virtually a good 
deal of the feather-bed business; but sheltering in a bed of kelp, and fastened to the long frond-like leaves, which floated for a hundred feet over the surface, where they acted like oil upon the waters, breaking up the waves and preventing our being swamped, was a different sort of rocking altogether. Crouching behind the low gunwales of the boats, to seek what shelter we could from the driving mist and icy rain, we sought to learn during the long watches of the night the great virtue of patience. Beetle-browed cliffs might rear their black crests inviting us to shelter and security, but their allurements had too often been tried and found wanting, even if we could have effected a landing.

Sometimes, when the weather was fine and only fog or distance prevented our finding the schooner, we sampled beds scooped out of the sand for a change. Dry sand feels soft and yielding to the foot, but as a mattress it will be found to differ very little from cast-iron.

Two consecutive days of warmth and brightness was too much to expect in this place of fog and storm, so that little surprise was felt when we turned up next morning to find ourselves blanketed in the usual fashion. Before we had finished our early breakfast, however, the fog began to lift in places, as a gentle air, stealing up from the southward, wove it into strange and fantastic shapes, only to be swallowed up and obliterated by cloudlike masses of descending vapour.

We got off in the boats by five o'clock, finding it clearer near the water than it appeared from the deck. As the day advanced, the fog lifted more frequently, disclosing lanes and patches of light, which looked like widening and extending into larger areas. About nine o'clock we were cheered by seeing an elevated paddle in the leading boat, showing that an otter had been sighted. Then began a long and exciting chase, rendered more so by the attenuated banks of fog which still clung to the water in smoke-like wreaths; and these the otter seemed to seek, as if knowing 
that they would baffle pursuit, and afford a shelter which his native element denied him; sometimes with long, exhausting dives, generally seawards, then breaching like a porpoise two seconds under water and one out, the leading boat watching his course by the string of air bubbles and pulling for all it was worth, the other two boats on either quarter ready to spread out to circumvent any sudden deviation from his course, and greet his appearance with a bullet. With undiminished strength, doubling under water, with long dives and short ones, now in one direction, now in another, and still unwounded, the chase had already lasted without intermission for two hours. But at length the dives became shorter, the boats could draw nearer, and it was only a question of a few more minutes before a well-placed bullet would end the contest, when, without a moment's warning, probably on account of our absorption in the hunt, down dropped the thin mist from above, while the surrounding wreaths and clouds that lay brooding over the still water swept over us like some gigantic bird, and, folding its great white wings, shut out sight and sound in its cold silence. The wind rose quickly, bringing with it more fog, and drove in our faces with wet and chilling breath that told of icefloes in the frozen north.

Twenty miles from land, whose direction we only knew from the compass, our otter lost in the mist, the little frail boats already dancing on the quick-rising sea, and the increasing roar of a tide-rip, in what direction we could not tell, there was nothing for it but to turn the boats landward, trusting to luck and the chapter of accidents. So, hoisting our sails, with frequent bailings, we skimmed over and through the disordered waves of the tide-rip. The wind died away as suddenly as it came, and, taking to the oars, we sought in silence the protection of the land.

It was well on in the afternoon before we struck it. Fortunately, the sea was quite calm, and we were thus able to coast along within fifty yards until there, should loom 
out of the fog some familiar rock or landmark which gave us our course so as to reach the schooner. Fortune, however, had not quite deserted us; for, before we sighted the land, we bagged a couple of otters which had been sleeping on the water, and, raising their heads in alarm at the sound of our oars, received their quietus ere they could overcome their curiosity and escape. Nor was our luck quite finished, for we were to have that evening the unique experience of seeing and shooting one of these purely pelagic creatures for the first and only time upon land.

With the boats hugging the shore here, fortunately free of outstanding rock, the coast line dimly visible through the fog, we rounded a tall, bluff, and rocky point; we turned inwards and came upon a stretch of sandy beach backed by a small plain or meadow of grass and stunted timber. Perched upon the white limb of a withered tree, with drooping wings and hunched up body, a very picture of sulky depression, sat a large sea eagle. I, who was in the leading boat, stole quietly upon it, hoping to get a shot; but, dejected as it might appear, the great, restless, searching eyes had already detected us, and, before the rifle could be raised, with a flap of its broad wings it disappeared into the mist.

Just as the rifle had been laid down, one of the men, pointing eagerly to the port quarter, whispered: "Racco, donnah, racco"-_ "Sea otter, master, sea otter." And there, sure enough, about a couple of yards from the water's edge, lay a dark, fur-clad creature with a yellowish head, which showed almost white against the dark background of rock, watching us intently. Seen for the first time on land, stretched at full length upon a little patch of sand amongst the rocks, it had little appearance of an otter, but some strange creation of this weird and uncanny coast. I snatched up my rifle and fired quickly, just as an intervening boulder hid it from sight and prevented me from seeing the result of the shot. Motioning the men to pull a stroke, the next moment they caught sight of it crawling slowly to 
the water, and, holding up my hand to stop the rowing and steady the boat, I took a steady aim and put a bullet through its head.

The boat was sharply backed to the edge of the beach, where a small stream emptied itself into the sea, and, jumping into the surf, I made my way as quickly as possible back over the rocks, just in time to lay hold of a large sea otter, for such it was that the waves were rapidly bearing off. This was doubly fortunate, for once it had reached the water alive it would inevitably have been lost in the dense fog, while if the sea had once got possession, it is doubtful, considering the great depth of water within a few yards of the shore, whether we should ever have seen it again. For although, unlike the seal, the sea otter rarely sinks when shot, we had already experienced one or two occasions in which they did so. When shot dead, the head drops at once, retaining what air there was in the lungs and body, while those we lost was after a long chase, the head being last to disappear.

Though differing somewhat in detail, we found all of the hunters practically unanimous in their opinion as to the strictly pelagic character and habits of the sea otter; some declaring that they never, under any circumstances, were found out of the water; others that they sometimes were, but very rarely; and others, again, that it was only when dying or very seriously injured that they sought the land.

The correctness of this is borne out to some extent by the structure of the animal, neither the hind, seal-like flippers nor the small, short fore-feet being adapted for the land. Upon examination of the body that night, when skinning it, we were inclined to the last belief, for we found the body, which was that of a full-grown female, or cow as they called it, dreadfully emaciated, having literally no flesh at all, while one shoulder and one hind flipper were broken. How the poor creature had got into such a state it was impossible to conjecture. But she had evidently swum to the shore and been left by the receding tide, and 
that but a very short time before our arrival upon the scene, for the sand around her was marked with fox or bear tracks. One of the latter was so fresh that, after getting the otter into one of the boats, we all then started off after it, late as it was. The footprints were enormous, and evidently belonged to a bear of great size; but, after following for some distance, the tracks crossed the stream where it was too deep to ford, and, as the night was drawing on, we were compelled to return.

The bed of this stream, the water of which was as clear as crystal, and in whose depths hundreds of small trout or parr were disporting, looked like white sand, but which we found to be pumice-stone, several lumps of which we picked up on the margin and took aboard with us.

When we regained the shore, and before re-embarking, we found several deposits of black metallic sand, which looked exactly like Curtis \& Harvey's glazed gunpowder. A sound chocolate tin, which we found opportunely jammed amongst the rocks, was filled with it and taken with us. It was found to be magnetic iron ore. After rowing some little distance, we fired a shot, and were answered from the schooner, which we soon found anchored not far from where we were. We were all tired and hungry after our long day, but well pleased, as we had managed to get three otters, in spite of the fog and our early ill-luck.

The little bay off which we were lying was made out by the skipper to be about $1 \frac{1}{4}$ miles long, lat. $45^{\circ} 8^{\prime}$, long. about $14^{\circ}$, and the third bay east of the large rock (Arch Rock) shown in sketch of anchorage of June i 7 th. A hole or cave extends right through Arch Rock, but it is only visible when approached from the south, and in the illustration lies behind the schooner's mainsail. 


\section{CHAPTER XIV.}

THE vivid contrast between the weather of the two preceding days might well have exhausted the meteorological vagaries of even this inhospitable coast, but when we turned out next morning we found another phase of its eccentricities in store for us.

All signs of fog had vanished and the sun shone out brightly from a clear blue sky; but it was blowing half a gale from the north-west, which gradually increased as the day advanced. Hunting was, of course, an impossibility. We saw the Flying Mist and Otsego, anchored in deeper water than ourselves, clear out of what we called Cygnet Harbourdoubtless on the lucus a non lucendo principle, as there was not the sign of a harbour or anything like it-and run down the coast. At about four in the afternoon we followed their example, but could make nothing of the weather, and at half-past nine we had to bring up in such anchorage as we could obtain a few miles south of our last position.

A heavy swell set in during the night, during which we spent an anxious time, for the short season was already far advanced, and to be blown out to sea and lose touch of the coast might mean days before we regained it. But our anchor held. The wind woollied down the mountain sides with terrific violence, lulling somewhat at times, but only to gain additional strength with each blast, as if intent to hurl us seaward.

One might have thought that the spirit legions of departed Samurai, far from their sunny southern shores, had found at once a fitting purgatory for their lives in this inhospitable land of mist and tempest, and their expiation in its defence. 
As the wind alternately whistled or screeched through the rigging one could almost hear the swish of the great two-handed swords, as with many a long forgotten war-cry they hurled their shadowy hosts upon the invaders who dared to violate the forbidden land with their presence. The roaring of the wind as it rose and fell between the blasts was the sounding of a thousand war gongs; while, above all, the deep rolling thunder of the great Pacific surges, as, curling their mountainous crests, they dashed themselves to pieces on rock and sand, was a fitting music for their onslaught.

The shelterless, harbourless nature of the coast, with its sudden and frequent storms, warring currents, and almost continual fog, together with the great depth of water and rocky bottom, was enough to banish all feeling of security during our anchorage; while the giant rollers-sometimes the precursors of a storm, or more often the effects of some disturbance far beyond our ken-would frequently set in without a moment's warning, during even the calmest weather.

In the early morning the wind dropped as quickly as it had come, leaving a big rolling sea, with a dense fog which lasted all day. The boats left at five in the morning and did not get back until after six that night. We only succeeded in getting one otter, and that one rather curiously. It was about three parts grown and one of the most active we had yet come across. It tried every device to throw us off, turning and doubling under water, always rising in some unexpected direction, giving little time for a shot, howevel hasty. Fortunately for us the dives were always short, for it was very foggy, and a fairly long dive would inevitably have shaken us off. As it was he kept us continually on the quivive for an hour. At length, he came up near one of the boats, which he did not at once perceive, and, receiving a shot, dived quickly, and came up the next moment quite dead.

I, who claimed the shot, was much disgusted, when, on skinning it that night, we failed to discover any sign of a 
bullet; in fact, it was quite untouched. Rupture of some of the principal blood vessels was evidently the cause of death, for the whole of the inside of the skin was a mass of extravasated blood, which considerably added to the disagreeableness of skinning and "leaning" - at no time a pleasant occupation. The rough opinion of the other hunters to whom we afterwards mentioned the circumstance was that, in its strenuous efforts to escape, it had broken or ruptured its heart-a similar instance being cited by one of the crew of the Caroline as having happened to him the preceding year.

It blew hard during the night, the heavy swell rolling us about uneasily, the dawn bringing with it a cold, heavy rain which continued without intermission all day, with a good deal of fog, but not quite so dense as it usually was. Towards mid-day the wind shifted to the east and blew more heavily than ever, so that we had to get underweigh and run for shelter to Jap Bay. We passed the Flying Mist, brought up off Sandy Bay, and at eight o'clock that night dropped anchor under shelter of the big bluff which bounds the north-east extremity of the bay.

August IIth.-The knowledge that this was to be our last day's hunting, and almost the last of our stay upon the coast, was still on the knees of the gods as we left the schooner that morning. Both wind and sea had dropped sufficiently by ten o'clock to admit of our hunting, but before we had been out half an hour the wind, which had fallen almost to a calm, commenced to blow great guns from the north-west. As the schooner was in no danger we rowed round the base of the bluff and found shelter from the wind. It was easy to see now how it was that all the great granite rocks that covered the shore were so beautifully rounded, for the great Pacific combers, travelling with racehorse speed, were sweeping over them tons of green water with a swiftness and violence that would have ground anything of less solid nature to powder.

In the small bed of kelp which lay off the point we 
came upon a school of about fifty otters. Now was our chance, had the weather only been more propitious; but, with the very few exceptions already mentioned, this was never the case. It only required one short dive seawards, and in a moment they were lost to sight amidst the stormy waters, already lashed into foam by the violence of the gale; and even the ardour of pursuit was damped by the certainty of being blown out to sea to perish miserably. With one eye upon the stormy water outside and the other upon the mountainous billows that broke like thunder upon the shore, rifle shooting was certainly at a disadvantage. But, in spite of everything, we managed to get a fine, fullgrown couple, whose curiosity, being greater than their timidity, proved their undoing.

In reading the early accounts of the discovery of the sea otter and its haunts by Europeans, and in view of the large numbers of them found together in immense schools, the natural inference is that they are gregarious in their habits. But our own experience, and that of other hunters with whom we came in contact, many of whom had followed this occupation for years upon the American coast, was quite opposed to this. The presence of any number of them in such quantity as to constitute a small or large school, as it is called, of from twenty to one hundred and upwards, was our experience only during or immediately after the prevalence of bad weather, and at such times they were resting or sheltering in the beds of kelp which, though but sparsely scattered along the coast and of comparatively small extent, were larger and more frequent along the American coast line.

Although large quantities of those molluscs and crustacea which form the principal food of the sea otter would naturally find harbourage around the roots and stems of these submarine forests, such pasturage would soon become exhausted; while their active habits and great natatory powers show conclusively how great are their wanderings in search of food. 
In such tempestuous waters, subject to almost continuous storms, as sudden as they are violent, with even the calmest sea quickly lashed to fury by the strife of conflicting tides and currents, not even the sea otter, in his native home and element, could struggle for any length of time without exhaustion against the flying foam and buffeting waves incidental to such surroundings.

With a fathomless sea behind, a surf-beaten coast in front, where was shelter or rest to be obtained?

Even if the structure of this curious animal had assimilated more to that of the land or river otter, from which it is as structurally different as it is from the seal, the protection of the land was impossible, if only on account of its inaccessibility. A fathom of green water fretted itself into foam against the base of grey-black cliffs that towered sullen and majestic above its petty strife, or broke in derisive showers of spray over such outlying boulders as were yet unconquered. Here and there some stretch of sandy beach broke the stern grandeur of the coast, appealing with strange wistful restfulness to the tired eye. But over this the great Pacific rollers, after a hundred miles of placid travel, were concentrating all reserve of weight and fury to dash themselves, reckless and impotent, upon the yielding sand.

But here, amidst the ocean forest of kelp that threw up its long elastic stems through thirty fathoms of blue water and floated its long narrow leaves hundreds of feet in length upon the surface, the sea that raged around was subdued and restful-the foaming crests subdued into an oily roll. Every now and again some keener gust lifted the edges of the great brown fronds, showing dark and solid like some submerged rock against the white background. It was to such oases as these, the only refuge from storm-swept sea or wave-girt coast that Nature could provide in such a tempestuous region for the hunted or the hunter. Here, singly, or in twos and threes, came the sea otter when driven from his feeding grounds by the inclemency of the weather. 
We were glad to row round the bluff and obtain such shelter as was possible from the violence of the wind.

With the boats lashed together and anchored to some kelp leaves, we had our lunch and waited, with such patience as we could command, the abatement of the gale. But the afternoon was well advanced ere we could venture to return. To keep a grip of the shore, our only guide, yet avoid being swamped by the great rollers that we could hear breaking unexpectedly into masses of seething foam and water long before they reached us, and through which no ship-much less our frail boats-could live, kept eyes and nerves upon the stretch. And rowing and paddling with all our strength in the face of the wind, with the everpresent pall of fog-now grown less dense, fortunatelyhanging over us, it took us four hours of incessant labour and battling before the schooner loomed out of the mist, much to our satisfaction.

Just as we had hauled the boats on deck and made everything snug for the night-a necessary precaution which we always observed, however late we might return-we noticed a large three-masted steamer bring up at our usual anchorage on the other side of the bay. This had for us rather an ominous appearance, suggesting further developments between Russia and Japan-probably an answer to some aggressive movement on the part of the former, whom we already knew had made something in the shape of a claim to the Kuriles. And although our sympathies were altogether with the Japanese, considering as we did that these islands were indubitably part of the Japanese chain, as far at least as Saghalien, the fact remained that, in any diplomatic affair, small people like ourselves were apt to find themselves between the proverbial millstones, with a good prospect of pulverisation. Moreover, we had already been warned that if we were again discovered within the three-mile limit, except through stress of weather or for the purpose of obtaining water, we should be taken prisoners, and our vessel confiscated. 
As soon, therefore, as it was dark, which was about an hour after we reached the schooner, we weighed anchor; and under foresail, jib, and staysail ran out to sea, intending to lay-to outside-certainly beyond the three miles. But hardly had we started when a gun was fired, and the steamer stood out after us. As the breeze freshened we hoisted the mainsail, and soon had the satisfaction of seeing her port light, showing that she had either not seen us or had abandoned the pursuit, and had turned her bows for Hakodate. Believing everything clear with the departure of the steamer, we put about and beat back to our former anchorage, which we were glad to fetch in the early morning, our last experience of losing touch with the coast having been quite sufficient to last us for some time.

We were congratulating ourselves next morning upon our good fortune in being left in peace, and so avoiding further complications, when, at about nine o'clock, the fog suddenly cleared off, disclosing to our astonishment and disgust the steamer, which we were under the impression that we had so cleverly avoided, lying placidly at anchor in her old position.

It was evident, therefore, that there had been two steamers; the one which we thought had come out after us had in reality been anchored there, though hidden by fog, and had left on the arrival of her consort, having in all probability never seen us.

The presence of two steamers, probably gunboats, boded us no good. So, full of conjecture, we waited impatiently for developments which were sure to come. It was impossible to put to sea, as it had fallen a dead calm, with bright sun and glassy sea; just one of those beautiful hunting days so rarely met with and so ardently prayed for, yet impossible under the circumstances to take advantage of. In fact, we felt very much like rats in a trap, waiting for the dogs to take a hand in the game.

After tiffin it was decided to put a bold face on the matter and send the skipper over to reconnoitre. So we lowered 
a boat and he set off, intending to board the steamer, whose nationality we were by no means certain of, as their flag at that distance was indistinguishable. Before he was halfway across, however, he was met by a boat from the steamer, which, after a brief parley, continued her course towards us; the skipper turning and following them. There was no doubt now that they were a naval crew, for the boat pulled twelve oars double banked, and we could see the glitter of uniforms.

All the otter skins which had been brought on deck to. dry were hastily put away, leaving a few which were still stretched on their frames as evidence of our occupation, and at which the crew were busily at work cleaning and scraping.

We exhibited neither surprise nor perturbation as a smart little naval officer, a captain of marines, and an interpreter stepped on board, and were shown into the cabin. They asked the usual questions-name of vessel, where from, etc.-also the somewhat momentous one, why were we here? To this we answered that we were in search of wood and water, of which we had run short. Where did we get water? Out of a stream close to where their vessel was lying, and to which we purposed coming as soon as a breeze sprang up. After this they left us, the naval officer having first written his name upon a piece of paper which he gave us, to show that we had been overhauled. They were very nice and polite, and, as a good breeze had just sprung up, we offered to take them in tow across. But this offer was declined.

We learned from the interpreter that the steamer was called the Osaka, and was the Admiral's yacht; also that her tender, a gunboat, was expected to join them that day.

As soon as they had gone we got underweigh, and followed them to the other side; but before we had proceeded far and had opened out the bay, we saw the tender steam round the bluff we had just left. The breeze had by this time lost its strength, and she rapidly overhauled us, 
lowering a boat as she came up, we going about on the other tack to meet it.

All the time the two steamers had been signalling with almost painful rapidity. An almost continuous string of flags might be seen ascending and descending the respective masts in gala-like profusion. As the skipper remarked, it was difficult to know whether they were signalling each other or signalling themselves. The conclusion we came to was that such a chance for practice was too good to be neglected, apart from the impression which such a display of maritime erudition would be likely to produce upon ourselves. Our conjecture upon this point seemed to be correct, the results being evidently less instructive to them than amusing to ourselves; for, when the officer boarded us, he expressed the greatest surprise on being informed that we had already been "spoken" by the Admiral's pinnace, and only the production of his predecessor's "chit" could convince him of the fact. He then left us, the signalling still proceeding furiously. Altogether we could not help being amused, though it is difficult to laugh at a people with so many elements of greatness in their character. A navy must have a beginning, like everything else; and, although our own was so familiar a part of our history as to seem lost in the mists of time, we might here see the inception of what might become as integral a portion of Japan's future greatness as ours was, and had been in the past. However amusing some of the things they did might appear to us, it was impossible to shut our eyes to the keen determination to master and assimilate all that was best in Western progress and civilisation that lay at the back of all their endeavours.

Not fourteen years had yet elapsed since the great European Powers had wrested from their unwilling hands the concession of Yokohama as a treaty port, and already this hitherto most isolated and conservative of nations had thrown out tentacles in the form of bands of students into all parts of the world. 
Animated with the highest patriotic fervour, and eager for knowledge, with the very language of their homes of exile still unlearned or understood, Argonaut-like they set sail on unknown seas for alien lands with eastern patience and northern determination, calmly satisfied in their own hearts that the end to be obtained was to be more for the good of their country than for themselves, and thus fully compensate for all the difficulties and drawbacks they must encounter. Years must elapse before they could hope to see again their sunny land; but when they should return, these little bands of ardent spirits, they would bring with them all that the distant west could give that was suitable to the genius of their people.

England would yield the secrets of her maritime supremacy and naval construction, France and Germany their great military organisations, and, from all, their legal codes, laws, and sciences.

And already their influences could be seen. War colleges had been erected, staffed with picked European teachers, and filled with eager learners; a nucleus for the navy of the future formed, and a mercantile marine created. Art they already possessed in no mean form. Literature, with its slow growth, might well be given time. The simple music of the shamisen and the kota was drowned in the martial strains of brass bands by performers whom but a year before had never even conceived the possible existence and fearsome appearance of these instruments which the world's highest civilisation had ordained and blessed as the most appropriate adjuncts to bloodshed and slaughter.

Nor had railways been forgotten or neglected, for already a couple of useful lines had been opened, with all their necessary paraphernalia, and crowded with business people and holiday makers, who had taken to the wonderful innovation as to the manner born.

Who can afford to laugh at a people like these, or who can say how far they shall not go? 
After the gunboat left us we continued our course across the bay and finally anchored close beside them about sundown.

On our way we were accompanied by three of the larger killers, or grampuses (Orca gladiator), who evidently mistook us for some unknown species of whale, and looked as if they meditated an attack, for they swam round about us in a very menacing and aggressive manner. Every now and then they would turn on their backs, showing their white bellies in vivid contrast to the polished glossy black of their backs.

This is the only species of whale which is habitually carnivorous, feeding only occasionally upon fish, but generally upon such warm-blooded animals as seals and whales, and no doubt also upon the sea otter. In fact, it is difficult to imagine how the latter could exist where the killer was found in any numbers.

We had several times come across them in small packs hunting amongst the half-submerged rocks after seals. They were extraordinarily bold, taking no notice whatever of the boats as they twisted and turned, regardless of our presence, like a pack of hounds puzzling out a scent. With its long, beautifully moulded form and broad, oval shaped flippers, the dorsal fin high and falcate, it gives the idea of great strength and swiftness. But, in spite of its symmetry and beauty, it has the distinctly menacing look and predatory appearance of the born pirate, and as such does not belie its reputation. Standing upon the deck and looking down upon the clear water, we had an excellent opportunity of observing their swift and graceful movements as they almost rubbed against the sides of the schooner while inspecting her.

The seal, white whale, and porpoise live in terror of this cetacean, running ashore or springing out of the water to avoid a pursuit as ruthless as it is implacable. The whaler hates it, as its appearance is a signal for the departure of every whale from the neighbourhood. For, combined in 
packs, they do not hesitate to attack a full-grown whale and destroy it.

Here we have another reason for the supposed gregariousness of the sea otter. Being no match for the grampus in the water and the shore inaccessible, a retreat to the beds of kelp weed would afford the only means of obtaining security from the attacks of the killers. 


\section{CHAPTER XV.}

WHEN we turned out rather later than usual next morning, the bay presented quite a festive appearance-a striking contrast to its usual desolation, for it was decorated with large flags of the rising sun, the Japanese national flag-a red sun on a white ground. These had been distributed along the shore every few hundred yards, and denoted something, very much more than a mere official visit of inspection. Three large tents had already been pitched and some forty men landed.

As possession is supposed to be nine points of the law, this was evidently the Japanese answer to Russia's claim to sovereignty over the Kuriles, and an earnest of their determination to uphold their rights by force of arms if necessary. We were all delighted at their pluck, however awkward it might prove for ourselves. As far as we knew, war might have been already declared, for before we left we knew that feeling already ran high at the suggested encroachments of Russia upon the southern half of Saghalien. Indeed, had a couple of Russian men-of-war steamed round the bluff at any moment, we should not have been at all surprised. This, at least, we understood, that it was the precursor of events in the more or less immediate future, for it stamped unmistakably the fact of rivalry in the Far East between the ambitions of the great northern colossus and the ardent patriotism, pluck, and determination of an essentially warlike race.* Was this to be the meaning of the railways, war colleges, and naval aspirations, the inner 
reason that lay deeper than commerce and peaceftil enterprise? One could only guess. But it looked as if this great awakening from the long sleep of isolation to the comprehension of its dangers had arisen from causes that had touched their feelings at its core. A nation whose gentry carry a special dagger consecrated to self-immolation sooner than they should face dishonour and disgrace, is apt to be as sensitive as they are patriotic. Results it is not good to prophesy. But history has an awkward way of repeating itself; and to primitive people belong those primitive virtues which have always made for success, while civilisation and patriotism are by no means controvertible terms. A single faith, a God, an idea seems to belong more essentially to primitive races than to those possessing what is called higher civilisation, but with whom are many gods and clashing interests.

Not in the men, but in the arms lay the great inequality of north and east. But the most modern weapons might be carefully selected from the world's great arsenals, purchased, and understood with as little difficulty as their bandsmen had mastered the technicalities of modern music. Time only was required, and this, most elusive of all, had already been taken by the forelock.

Was this to be the opening scene in a great drama? It did not seem likely; most probably the farce-the drama could wait for another twenty years.

As soon as we had finished breakfast and the boats sent ashore for wood and water, we were visited by the naval officer who had first boarded us on the preceding day. From what he said, they were very anxious for us toleave as soon as possible, and wished to know whether we could not sail by mid-day. On our reply that it would be necessary to overhaul sails and chafing gear, he offered to send us their sail-maker, and, indeed, give us any assistance, required, also send us water. He also examined and cross-examined our crew, who told us after he left that they were desirous of impressing some of our men 
to assist them in otter hunting; but the crew would not agree to serve willingly, being anxious to return home. So the matter was dropped; more especially, no doubt, as our departure was more eagerly desired than anything else.

We also learned from our men that one of the gunboat's men, named Yuski, had been killed by a bear, which he had wounded and followed up alone. Baker knew the man, who had served under him in another gunboat, and described him as having always been a very venturesome fellow, and rather foolhardy.

Declining their offers of assistance, we finally promised to leave as soon as our complement of wood and water had been received. With this our naval friend left us, after enjoining us on no account to return to Onabetzu, as it would only result in the confiscation of our vessel and cargo.

We had to be content with this, as there was no appeal; and, as far as we cou!d tell, they were strictly within their rights.

We were also informed that still another gunboat was expected; and, as it was now the middle of August, with a season of still worse weather and heavier storms with, perhaps, the tail end of a typhoon thrown in approaching, besides the prospect of being harried by gunboats, the game would scarcely be worth the candle, and we came to the conclusion that we must consider our cruise at an end.

So at two o'clock we weighed anchor, saluted the yacht, and turned our backs sorrowfully upon the familiar bay, which had grown almost home-like to us, and behind whose arms we had so often sheltered. And yet, before little more than a year should pass, our gallant little vessel, that had carried us through so much, was to return, only to have her timbers piled up on the sandy shore for ever.

The story of her loss may be briefly stated here. Snow, with another crew and companions, came up to hunt in 
the year following, and had anchored for the night in seven fathoms of water about the middle of the bay, when a tremendous sea set in suddenly, followed by a gale of wind, and, before the frozen sails could be unloosened, the great Pacific rollers had got her in their grip and had pitched her like a cork upon the shore. No lives were lost, fortunately, but they spent a miserable six months in the little fishing settlement on the other side of the island until rescued by a cruiser and taken to Hakodate.

We carried a good breeze with us for a short time only before it fell a dead calm, which continued with the usual dense fog until the following afternoon, when it cleared up a bit, when we found ourselves beyond Otter Island and close to the southern extremity of Yetorup. We drifted about in a cold, wet fog and rain all that night, with occasional light breezes springing up and dying away as suddenly as they came. A school of enormous fin-back whales or rorquals passed slowly close alongside of us, dwarfing our seventy odd feet of length with their grand proportions. The night was lighted up with a grand display of sheet lightning; but we got little rest as we were tossed and tumbled about, until we thought we should roll our masts out, in the grip of a tide-rip which seems always to be running off either end of the island. Morning found us abreast of the island of Shikotan, a gentle two-knot breeze fanning us along all day on our southerly course.

The fog got lighter as we left our inhospitable hunting ground farther astern, enabling us to see the varied bird life that peopled the waters. Flocks of dusky petrels, boatswain birds-with and without their long tail feathers -and Mother Carey's chickens, besides gonies, while albatrosses and many others surrounded us on all sides.

A large sword fish jumped high out of the water five or six times close beside us, no doubt in the endeavour to escape those cruel hooked teeth of a grampus which was hunting it with all the persistency and relentless ferocity of its kind. During the night our starboard quarter was struck 
a severe blow, evidently by one of these small whales, which made the vessel quiver; nor were we sorry that the experience was not repeated.

With light airs and variable for the next two days, we sighted Cape Yerimo in the evening and were abreast of it next morning, air still very light. There is an ancient marine story that tells how Polly of Portsmouth, cursing her defaulting lover, and praying that his approaching voyage should be one of continuous storm and tempest, was corrected by the old and more experienced bumboat woman. "Nay, nay, my lass, wish him light winds and variable." And she was right, for when the ship is "laid to" in a storm Jack may go below and sleep; but with light and variable winds his work, pulling and hauling on braces and sheets, is as exhausting as it is unending.

Cape Yerimo ends in a reef of giant boulders and pinnacled rocks, on some of which houses are built, stretching about a couple of miles from the shore. For about eight or ten miles inland the land is comparatively low, backed by mountains-according to the chart some 3500 feet in height-while these, again, were in turn overshadowed by a range considerably higher.

We sailed slowly past two large junks laden with passengers, amongst whom we saw many gaily dressed women and children, and across the quiet water floated the well-remembered strains of a shamisen or kota.

Alas! gentlest and merriest of all womenkind, with their beautiful manners, exquisite politeness, and kindly little hearts, who would rather step aside than tread upon a worm, how little did they know that life's last sunset had been passed!

The setting sun was gilding the quiet waters with crimson and gold, the sky a deep blue and cloudless, and the gentle air, freshening somewhat, scarce ruffled the surface of the sea.

But, unknown to us all, the great storm fiend, the dreaded typhoon, already brooding over us, was gathering together 
with fell purpose all its forces of destruction, and was only holding its hand until darkness should add to its terrors; and we, speeding homewards under the ever freshening breeze, should have entered the narrow straits where sharp pointed rock and hidden reef would complete the work of ruin that wind or sea should fail to accomplish.

Like the passengers in the junks, we too, were merry, for was not our cruise as good as completed. Ever since leaving Jap Bay, our progress had been exceedingly slow, the winds being very light and baffling. Taking a straight course from Hitokatpu Bay (Jap Bay) to Cape Yerimo, which would be about S.W. half W., would just pass inside the island of Shikotan and cut Nemoro, the distance is about two hundred and eighty miles. Then W. half S. past Cape Yesan to Cape Blunt-on chart, Siwokubi-one hundred miles, then W. by N., twelve miles to Hakodate Head. It was now August 2 Ist, and we had only averaged about fifty-seven miles a day. A good deal of our progress was no doubt owing to the favouring impulse of the Oya Shiwo, or Arctic current, which, sweeping down the Pacific side of the Kuriles and the south-east coast of Yezo, meets the warmer Kuro Shiwo about Inuboye Saki, where these waters mingle. The spring temperatures north and east of this cape being respectively $40^{\circ}$ and $60^{\circ} \mathrm{F}$. The temperature off the Kuriles varying from $30^{\circ}$ to $36^{\circ}$ during the summer.

After two o'clock the wind began to freshen steadily, and from four to six we were bowling along with everything we could carry, with every prospect of anchoring in Hakodate Harbour in the course of a few hours. Six months' growth of beard and whiskers had been shaved off and the garb of civilisation assumed. But we did not know what was before us. By six o'clock we were abreast of Cape Shiriya, the eastern extremity of Niphon which marks the entrance to the Tsugaru Straits. The wind steadily increased during the next two hours, when it was blowing with hurricane force, making it advisable for us to "heave to," which we 


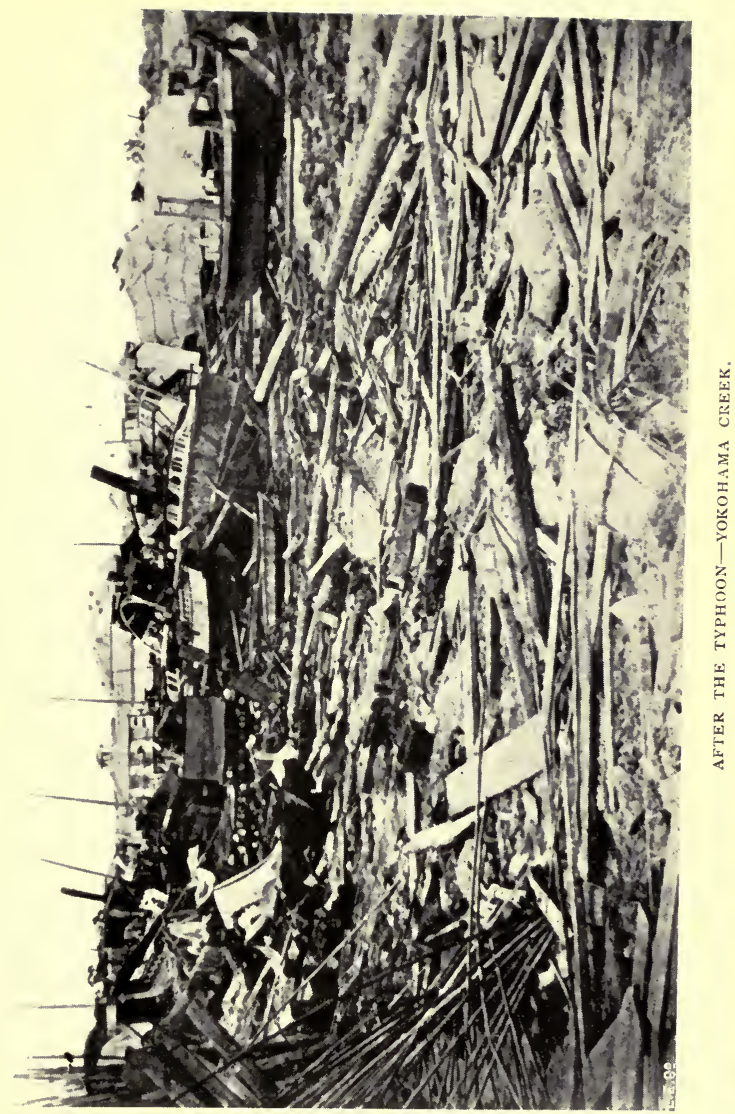



did under double-reefed foresail only. The barometer, which stood at $29^{\circ} 80$ at eight o'clock, had begun to fall ominously. It was now evident that we were in for one of those dreaded typhoons which, during late summer and autumn, devastate these eastern seas. The air grew thick with vapour, enveloping us like a fog, obscuring the sky and everything but the white foaming water that shone out of the black darkness of the night. With stores and water nearly exhausted, we were very light, and our breadth of beam and little hold of the water kept the decks comparatively dry as we danced like a cork upon the now raging waters. But the spume and spindrift, caught up from every wave-crest, flew over us with all the violence of a tropical rain-storm. Every few minutes one of us would have a look at the barometer, but only to find it still falling. Before midnight the wind had increased so much that we took another reef in the already double-reefed foresail, which was all we dared carry.

Before daylight had disappeared, we were no great distance from the dreaded Whaleback-a low, long rock, almost awash, shaped, as its name implies, like a sleeping whale, which lay on our port side off the Niphon shore, upon which so many vessels had been wrecked. And, judging by our drift and the direction of the wind, we must be gradually nearing it. At the mercy of wind, wave, and current, at any moment we might strike it or the neighbouring shore. No boat could live in such a sea, so we made no attempt to prepare them; but we had a lower mast lashed along the port rail. This, cut loose at the right moment, might afford some small chance if it came to the worst; though how small that chance would be could be seen by one glance at the seething waters. As is usual in such cases, the crew were called aft, so that all chances would be equal. Peril is a great leveller, and a man's pedigree is seldom asked under such conditions. One could scarcely help smiling at their appearance, for several of the men, who had donned their long dressing-gown-like 
kimonos, looked more like expectant bathers than sailors. But, good swimmers as they all were, they knew very well how little that would avail them in such a sea, so that dress at such a time was a matter of little importance. Judging by experience, death under such circumstances, or rather its anticipation, is not so hard as it is generally considered. The struggle must necessarily be short, and, numbed with cold and fatigue, the final restfulness cannot be unwelcome, and thought is all concentrated in regrets for the sorrow of those that are left behind. Especially is such the case where the sca does not give up her dead, and hope, often unreasoning, keeps sorrow alive.

Shortly after midnight the rain began to descend in torrents, but without having any influence on the wind, while adding to our discomfort, as it cut our faces like the lashings of a whip. At one o'clock the foresail, which we had been so anxiously watching, split into ribbons with the fierceness of the wind. We then set the jib, a comparatively new sail, but it could not stand five minutes before it also was split into rags. The mainsail, already close reefed in readiness, we dare not set, as it was now our last hope and could only be used at the very direst extremity. Indeed, no canvas could have stood against such a wind, so at the mercy of the wind and sea we drifted bodily towards the lee shore. Baker never left the wheel, trying to ease her as much as possible. But he, who was by far the best sailor amongst us, had added to our anxiety by declaring some time previously that what he principally feared was our being capsized, a by-no-means unlikely contingency, for the wind and current together had raised a tremendous cross sea that raged around us in strange, unwavelike shapes of mounds and pyramids that tossed us up or sank beneath us as, unbalanced on their crests, we pitched and rolled until we thought the masts were going overboard. Every now and then some great pyramid of water rose alongside whose toppling summit was seized by the hurricane and fell, flooding us with water. At last the ever-falling glass 
steadied, after having fallen from $29^{\circ} 80$ to 29.34 , and a little later showed a tendency to rise, showing that the greatest violence of the typhoon had passed.

By three o'clock the dense mist-laden air had become thinner, and the rain stopped. With eager eyes we tried to pierce the black darkness of early morning; for, owing to the circular nature of these storms, the wind had already gone round half the compass, and it was impossible even to conjecture what our position might be, although the general trend of our drift had been towards the Niphon coast. Nor were we far wrong, for first dimly as a cloud, but getting plainer every minute, there rose out of the darkness, almost towering over us, a range of black cliffs upon which we were rapidly drifting.

The dreaded "Whaleback" could not be far distant, and any moment we might strike it or some outlying rock.

It was now or never, and, although the wind still blew with hurricane force, it had certainly moderated somewhat. The sea was, if possible, more turbulent than ever; but the glass had ceased to fall. But it was impossible to allow ourselves to drift any longer, and the time had come to take our last hazard with the mainsail. If it held, we had a chance; if not, the deluge. Close reefed, until it looked like a woman's shawl, we got it set at last; and surely few sails have been set as carefully or watched as anxiously as that mainsail of ours. But it was new and good and held famously. Before long we ventured to set the staysail also; and, steadied and controlled, we saw the dark cliff melt into the darkness as the schooner eat her way towards the more open waters of the strait. But the hour that passed before the dawning of the day showed us our position was an anxious one. Apart from our sail holding so well, we found that we owed our safety to the circular nature of the storm, which, giving us a freer wind, had enabled us to work ourselves out of a most perilous position.

Long before noon both sea and wind had gone down, 
and settled into a deep calm; and we found we were in the grip of the current which, flowing through the Tsugaru Straits at about four or five miles an hour, was gradually drifting us out to sea and away from our destination.

While Snow and the skipper went below for a muchneeded rest, Baker and I sewed up the jib, set it, and, rigging a main staysail in the place of the tattered foresail, a few ribbands of which only remained to remind us of the night so lately passed, we strove to take advantage of every air that offered to hold our own against the adverse current.

During the day we drifted by the wreck of one of the large junks which we had passed the preceding night, crowded with her happy family of passengers and crew.

Her great bulk, surmounted by the huge square sail, which had towered above the quiet waters so short a time before, had all disappeared before the fury of the typhoon. The high-peaked stern and all her upper works had vanished, and only the lofty prow and a few rugged timbers rose above the surface of the now placid sea. The scorching sun shone pitilessly down upon the saddest scene of a sailor's life. A gentle swell raised and lowered the poor bruised timbers in rhythmic motion and mute protest to the great Sun God who, hiding his face in the black darkness of the night, had let loose the cruel wind dogs of havoc and destruction. Not all his smiles or glinting rays reflected from the wet timbers, so untimely shattered, could warm them into shape, or bring back the flush of life to the merry little faces which but a few hours before had turned admiring eyes and uplifted hearts as the great Sun God sank beneath the waters in his golden setting. Verily the gods have strange and unaccountable ways of manifesting their divine attributes to poor suffering humanity. One could not help thinking that the chastening process had better fallen upon ourselves, with our ruder speech and rougher manners, than upon the gentle little daughters of the Rising Sun. 
The inbred stoicism of these people, who have within them so much that is great and enduring, only served to darken the picture. Little blanched faces, a very few tears, a little wondering at the strange decrees of Fate, and a quiet acceptance of destiny at the hands of the gods.

All that day and night the wind blew fitfully, with sometimes a stiff breeze, but never for long; and morning found us little more advanced than the entrance of the strait.

As the sun mounted higher in the heavens it glanced and glittered on innumerable logs and timbers that literally lined the tideway on either side. They were all that remained of hundreds of junks and sampans that but a few hours before had danced so merrily upon the treacherous waters. It was impossible to witness more terrible evidences of the destruction wrought upon the native shipping during one of these devasting storms than those which met our eyes on either side of the current way as, packed in long lines within the shelter of the eddies, they lay like long strings of rafts moored beyond the influence of the current. Gathered by the strong stream from the surrounding coast, they sheltered for a time, until varying winds and restless waters should make their final distribution.

We passed another huge junk, or rather its skeleton, that floated past us as we barely held our own against the tide. The high prow and a few ribs was all that remained of what was in all probability the second of the two large passenger junks that we had sailed by before the coming of the typhoon.

Amidst light airs, stiffening occasionally into a breeze that urged us onward towards our destination, and intermittent calms that left us at the mercy of the strong Tsugaru current, we barely held our own.

But we welcomed the coming night that would shroud in more becoming gloom the sunlit waters that could flash and glitter in such jaunty derision upon its own handiwork of 
floating timbers and scarred ribs, the sole remains of many a lofty junk and lowly sampan, and hide from our sight a scene so full of sorrow and destruction.

It was two days later, or four days after the typhoon, when we rounded Hakodate Head and found ourselves at last beyond the power of the current. As our little craft lay almost motionless under the midnight shadow of the great bluff, we were much exercised in our minds by the passage of two great men-of-war that, with all lights out, issued like vampires out of the darkness and stole silently past us up the harbour.

It almost seemed as if we had only avoided Scylla to fall into Charybdis, for if they were Russian ships bent upon a bombardment of Hakodate, our position could not be over pleasant; while, judging by the state of affairs when we left, and with no news for four months, it did not seem at all unlikely that hostilities might have commenced.

Daylight, however, dispelled our doubts ; and later, as we fetched our old anchorage, we found the bay gay with the flags of two English as well as a couple of Russian menof-war, intent upon nothing more serious than the usual naval courtesies. Everything was bright and peaceful as the sparkling water of this beautiful harbour.

Amongst the shipping we found many evidences of the violence of the typhoon from which we had so recently escaped. One large barque, the Lizzie, from Shanghai, had her bulwarks smashed and only her foremast standing. The skipper, as well as the owner, who had come up for the trip, told us afterwards that had not the crew-which, by the way, they described as the most desperate set of ruffians they had ever handled-worked as only British seamen can when they choose, they would certainly have been lost, for in the height of the storm she lay for long on her beam ends, until the cutting away of the masts relieved her.

Our hunting cruise was now at an end, and, leaving my 
companions with regret, as I was anxious to reach England by Christmas, I booked a passage in the Japanese passenger steamer Sakura. But, at the last moment, to oblige friend Thompson, our kindly host and builder, shifted my belongings to the Hokaido, the topsail schooner which he had been building when we started on our cruise, and now, rather shorthanded, there being only two Europeans on board, skipper and mate, was just starting on her maiden voyage to Yokohama.

It was fortunate that I did so, for, on reaching our destination ten days later, we learned that the Sakura had been lost with all hands in another typhoon, which, extending as far as Hong Kong, had done an enormous amount of mischief both there and at Yokohama. At both these places I found the hatoba, or sea front, as if it had been bombarded, with houses unroofed and wrecked, while several large steamers lay piled up on the roadway.

Our own voyage in the Hokaido was sufficiently eventful, as we experienced the full fury of the storm. Most of our time was passed lashed to the rigging, with tackles on to the lanyards, tightening the shrouds; which, being new, stretched so much as to continually endanger the masts. We had started with the deadeyes about eight feet apart, but when our short voyage was over there was not eight inches between them.

A few days after landing I took the train to Tokio to bid some friends good-bye, and, when entering the station-yard, the native pointsman cleverly shifted the lever when the train was about half over the points. Beyond being thrown from one end of the carriage to the other on the top of a stout old gentleman travelling with two little boys, all the occupants of our carriage escaped unhurt. But we had to dig the fireman from under the tender, and the carriage in front of ours was reduced to matchwood, the framework alone remaining half-way down the embankment. Many were killed and injured. Later in the day, returning in a wagonette, as the line was still interrupted, the horses took 
fright, and I was pitched out, but unhurt. Two typhoons at sea, a railway and a carriage accident on land, in less than a month, tempered my regret at leaving one of the most beautiful countries, excellent sport, and a most delightful people, with whom J had sojourned for some years.

FINIS. 


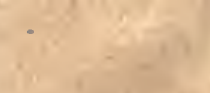

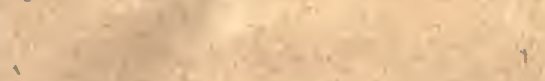

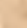

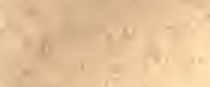

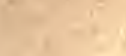

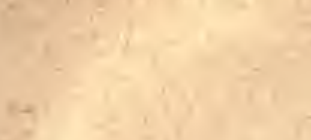

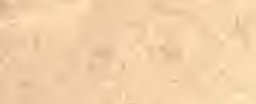

(2)

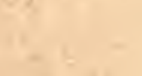

r

$7+11-1$

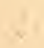

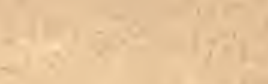

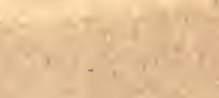

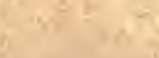

,

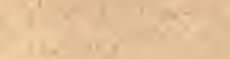




\section{UNIVERSITY OF CALIFORNIA LIBRARY \\ Los Angeles}

This book is DUE on the last date stamped below.

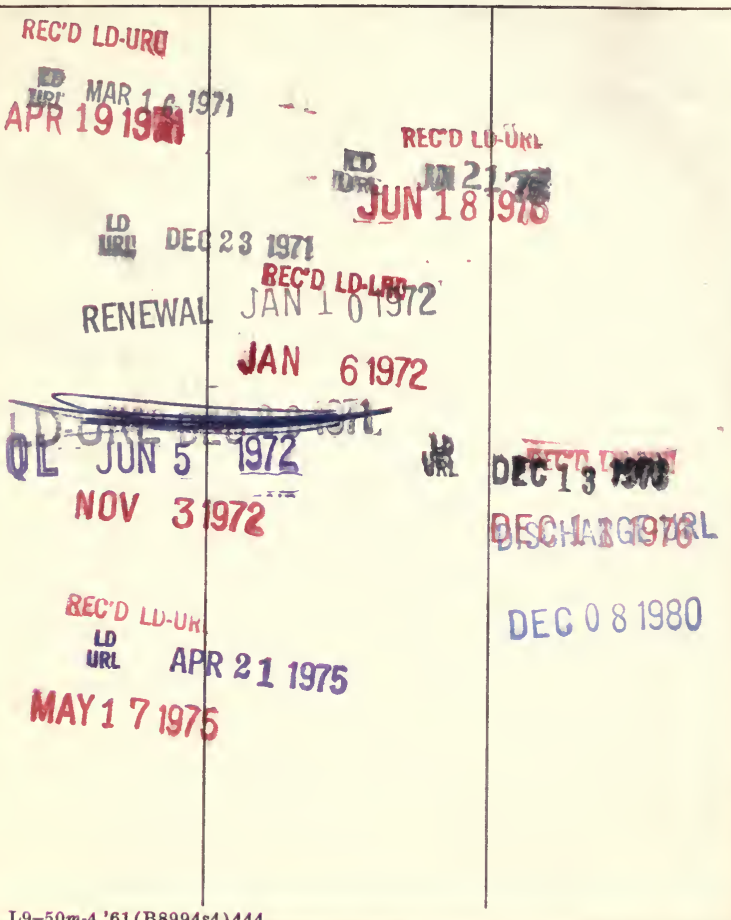


UC SOUTHERN REGIONAL LIBRARY FACIUTY

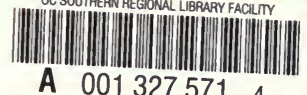

$\begin{array}{ll}- & A \\ \sim & \\ \therefore & \end{array}$

PLEASE DO NOT REMOVE THIS EOOK CARD

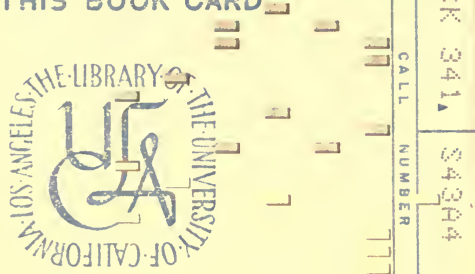

University Research Library
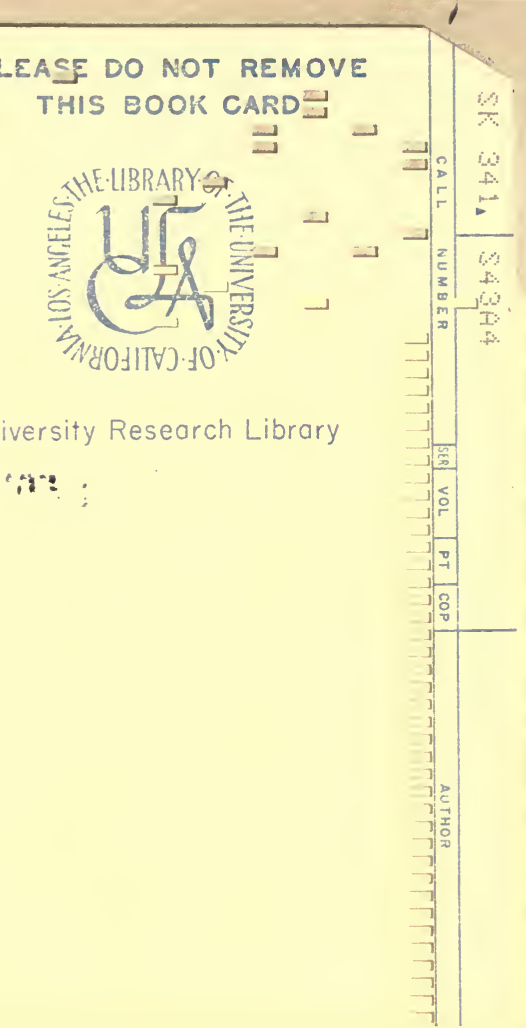


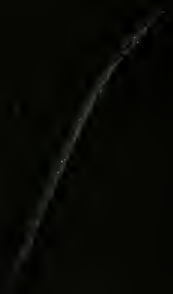

